\title{
A WTO AGREEMENT ON INVESTMENT: A SOLUTION IN SEARCH OF A PROBLEM?
}

\author{
KEVIN C. KENNEDY*
}

\section{INTRODUCTION AND BACKDROP}

As global competition for foreign direct investment intensifies, the question pending before the World Trade Organization ("WTO") is whether to negotiate an agreement on investment that would address, inter alia, national laws that restrict market access of foreign capital. ${ }^{1}$ In the intervening years between the Singapore Ministerial Conference in 1996 and the latest Ministerial Conference held in Doha, Qatar in 2001, several WTO members (including the European Union, Japan, and Korea) and commentators urged the WTO to include on its agenda negotiations leading to multilateral rules on investment. ${ }^{2}$ Demands by the European Union ("EU") for a comprehensive trade negotiation round that includes negotiations on investment could very well be a red herring intended to draw attention away from negotiations on agricultural trade reform and the EU's common agricultural policy ("CAP"),

* Professor of Law, Michigan State University-Detroit College of Law, J.D. 1977, Wayne State University Law School; LL.M. 1982, Harvard Law School.

1 At least one WTO member has characterized the question as one of understanding "what is missing in the current WTO framework." WTO Working Group on the Relationship Between Trade and Investment, Submission from Canada, at 2, WT/WGTI/W/19 (Dec. 11, 1997).

2 See, e.g., Daniel Pruzin, EU Advocates GATS Approach to WTO Talks on Investment, Offers Nondiscrimination View, 19 Int'1 Trade Rep. (BNA) 1218, 1219 (July 11, 2002); Daniel Pruzin, EU Official Says Support Growing for Comprehensive Trade Round, 16 Int'l Trade Rep. (BNA) 1284 (Aug. 4, 1999) [hereinafter Pruzin, EU Official]; Daniel Pruzin, Japan Discussion Paper Highlights Likely Issues for WTO Talks on Investment Rules, 18 Int'l Trade Rep. (BNA) 881 (June 7, 2001) (describing Japan's call for WTO negotiation on investment rules); Daniel Pruzin, Prospects Diminishing for Talks on Rules Covering Investment, Competition, 16 Int'l Trade Rep. (BNA) 1598 (Oct. 6, 1999); Daniel Pruzin, U.S. Offers Olive Branch on Talks at WTO on Investment, But Not Inside Seattle Round, 16 Int'l Trade Rep. (BNA) 1779 (Nov. 3, 1999); Co-operate on Competition, ECONOMIST, July 4, 1998, at 16 (calling upon the WTO to issue multilateral competition policy); The Borders of Competition, ECONOMIST, July 4, 1998, at 69 (suggesting WTO including minimum competition policies). 
the proverbial "third rail" of EU politics - that is, if any EU politician touches it, their political life is finished. ${ }^{3}$ Before the start of the aborted Seattle Ministerial Conference in 1999, the United States took the position that negotiations on a WTO investment agreement should not be part of any new multilateral round of trade negotiations. ${ }^{4}$

3 See Raj Bhala \& KeVIn Kennedy, World Trade LaW: The GaTT-WTO SYSTEM, REgIONAL ARRANGEMENTS, AND U.S. LAW 1188 (1998) (noting that "the CAP is a highly charged subject"); Daniel Pruzin, EU Official, supra note 2, at 1284 . Without question the most politically charged of all the EU common policies, both within and outside the EU, is the common agricultural policy. Article 32 of the Treaty of Establishing the European Community ("EC Treaty") directs the EU member states to develop a common agricultural policy. See Treaty Establishing the European Community, Nov. 10, 1997, O.J. (C 340) 3 (1997) [hereinafter EC Treaty]. Article 33 of the EC Treaty identifies the CAP's five objectives: (1) to increase agricultural productivity, (2) to ensure a fair standard of living for farmers, (3) to stabilize markets, (4) to assure availability of supplies, and (5) to ensure that consumers pay reasonable prices. Id. art. 33. The EC Treaty offers no details on how these five objectives are to be accomplished, but instead leaves it to the Commission and Council to work out proposals and directives. Id. arts. 34-37. The Commission has adopted three principles to guide it in developing the CAP: (1) with the single market concept as the polestar, agricultural products must move freely within the EU and be sold at stable prices set by the EU; (2) priority should be given to EU-origin agricultural products to protect them from cheaper imports; and (3) the costs of the CAP must be shared. See European Commission, Activities of the European Union, Agriculture: Introduction, at http://europa.eu.int/scadplus/leg/en/lvb/504000.htm (defining instruments used for EC agricultural policy); BHALA \& KENNEDY, supra, at 1185-86 (stating that the CAP's main objective is "food self-sufficiency"). Some of the thorniest issues that the EU has had to grapple with in framing the CAP have included the question of food self-sufficiency, stable prices for farmers and consumers, and adjustment to international trade competition. See BHALA \& KENNEDY, supra, at 1178-80 (providing an introduction to GATT-WTO agricultural concerns). Under the CAP, huge food surpluses have been created that are sold in world markets at prices that severely undercut the prices of those same products offered by other agricultural exporting countries, including the United States, Argentina, and Australia. See Amy Kaslow, Farm Subsidies Create Bounty, Boondoggles, CHRISTIAN SCI. MONITOR, Nov. 4, 1992, at 12 (discussing the negative effects of farm subsidies). Agricultural trade wars have been the result, with one country undercutting another country's exporter's price by subsidizing exports to third countries. See BHALA \& KENNEDY, supra, at 1186 (noting further the problem of agricultural overproduction resulting in bidding wars); Will These Modest Proposals Provoke Mayhem Down on the Farm? ECONOMIST, July 13, 2002, at 42 (analyzing the EC's agricultural aid policies).

4 See Daniel Pruzin, U.S. Outlines Priorities for WTO's Seattle Ministerial, 16 Int'l Trade Rep. (BNA) 1285 (Aug. 4, 1999). The United States was joined by the Association of Southeast Asian Nations ("ASEAN"), India, Mexico, and Pakistan. See Daniel Pruzin, Seattle Ministerial and Beyond: A Long, Winding Road for WTO, 16 Int'l Trade Rep. (BNA) 1975, 1977 (Dec. 1, 1999). 
The arguments for a binding, multilateral legal instrument on foreign direct investment ("FDI") 5 can be briefly summarized as follows:

(1) A multilateral investment agreement is an important development tool because it will attract FDI that will in turn improve

5 Investment can be divided into two broad categories: portfolio investment and direct investment. The former involves acquiring shares of corporations without exercising any direct control over management of the organization. Direct investment, in contrast, involves acquiring a significant controlling interest of an existing foreign firm or establishing a new firm (the latter is sometimes referred to as a "greenfield" investment). One measure of a controlling interest is that an investor must hold at least ten percent of a firm's equity in order for that investment to be classified as a direct investment. See Approaching the Next Frontier for Trade in Services: Liberalization of International Investment, Industry, Trade, \& Tech. Rev., April 1996, USITC Pub. 2962 at 2 (distinguishing between portfolio and direct investment). It is management control that distinguishes direct investment from portfolio investment. As used in this Article, the term "foreign direct investment" refers to direct investment, including the purchase or sale of business enterprises (mergers and acquisitions) and the establishment of a fresh or "greenfield" investment.

Foreign direct investment can be further divided into three types: horizontal, vertical, and distribution. WTO Working Group on the Relationship Between Trade and Investment, The Relationship Between Trade and Foreign Direct Investment, Note by the Secretariat, at 3-4, WT/WGTI/W/7 (Sept. 18, 1997). Horizontal FDI refers to investment in facilities producing the same line of products in different countries. This type of investment occurs when a product has a high weight to value ratio and is thus expensive to transport (e.g., cement). Horizontal FDI can also occur in order to jump a high tariff wall. Horizontal FDI tends to occur in host countries with a large domestic market for the product in order to achieve economies of scale, or in smaller countries which can serve as an export platform to the adjacent region. Horizontal FDI displaces some exports of final goods from the home country, but tends to generate offsetting trade in intermediate goods. See id. at 13-15 (describing in detail horizontal FDI).

Vertical FDI refers to investment in production facilities that manufacture different stages of a product in different countries. The location of each stage is chosen to minimize total production costs. For example, extractive industries are found where the raw material is plentiful. Similarly, energy-intensive and laborintensive industries are located where energy and labor costs are low. By its very nature vertical FDI is trade-creating, because it subdivides the production process of a single product between or among countries. Trade barriers in both the host and home country discourage vertical FDI. Tariffs imposed by the host country on intermediate goods sold to an affiliate will raise the cost of the product. If the final product produced abroad is later exported to the home country, and tariffs are also assessed on the imported final product, then in combination the tariffs of the host and home country may make a vertical FDI uneconomic. However, such tariff barriers may encourage horizontal FDI. See id. at 16-17 (detailing the modern view of vertical FDI).

Distribution FDI refers to investment in local sales offices, distribution networks, and services facilities. See id. at 17-18 (stating, "[B]ut also in marketing, distribution and service-related activities ..."). 
competitiveness and promote the transfer of technology and managerial know-how from home country to host country.

(2) A multilateral investment agreement will introduce greater transparency, predictability, and legal security in the FDI process.

(3) National legislation provides inadequate legal protection for FDI and is, thus, not an alternative to a multilateral agreement. Stated slightly differently, a multilateral agreement on investment has insurance value in that it gives a foreign investor greater confidence that a host country's national investment laws and policies will not be changed at the whim or caprice of national leaders to the detriment of the investor. To a lesser extent, a multilateral investment agreement might be some insurance against corruption by local officials in the host country.

(4) A multilateral investment agreement will bring policy coherence to the "spaghetti bowl" of bilateral and regional investment treaties. ${ }^{6}$

(5) Countries that are not parties to bilateral or regional investment agreements are marginalized or cut out as beneficiaries of FDI inflows. As parties to a multilateral investment agreement, they will be part of the mainstream.

(6) A multilateral investment agreement will eliminate resort to wasteful investment incentives to attract FDI. ${ }^{7}$

(7) A country that is a party to a multilateral agreement on investment will enhance its credibility as a place that is hospitable to FDI. ${ }^{8}$

According to the Organization for Economic Cooperation and Development ("OECD"), the greatest value of a multilateral

6 Zdenek Drábek, A Multilateral Agreement on Investment: Convincing the Sceptics 4-5 WTO Econ. Res. and Analysis Div., Working Paper ERAD-98-05, Feb. 1998) (providing "powerful arguments in favor of $\mathrm{MAI}^{\prime}$ ).

7 Id. at 5-6.

8 See Bernard Hoekman \& Kamal Saggi, Multilateral Disciplines for InvestmentRelated Policies? 15 (unpublished paper presented at conference on Global Regionalism, Feb. 8-9, 1999) (on file with author) (arguing that FDI is a "credibility enhancing institution"); James R. Markusen, Multilateral Rules on Foreign Direct Investment: The Developing Countries' Stake 51 (World Bank Study Paper, Oct. 1998) (discussing the insurance value of such a treaty).

9 The Organization for Economic Cooperation and Development ("OECD") was founded in 1961 . The OECD is the primary organization for highlyindustrialized and industrializing nations to discuss trade, investment, and other economic matters of mutual interest. Its objectives are to achieve economic growth and employment in member countries while maintaining financial stability. Its twenty-nine members include the fifteen EU member countries, Australia, 
agreement on investment is the stability, predictability, and transparency it brings to the legal environment:

International rules have much to contribute to the stability of the multilateral system by helping avoid distortions to production and trade and in promoting more stable investment flow's, higher quality investments and a better distribution of their benefits. Adherence to rules may be especially valuable to countries whose share of international investment falls short of their needs, as well as to small and medium-sized enterprises that might otherwise hesitate to invest outside familiar territory. Rules offer transparency and predictability for investors, and a vehicle for international co-operation and dispute resolution. ${ }^{10}$

Canada, the Czech Republic, Hungary, Iceland, Japan, Korea, Mexico, New Zealand, Norway, Poland, Switzerland, Turkey, and the United States.

Along with the WTO and the United Nations Conference on Trade and Development, the OECD has actively studied the subject of foreign direct investment and the role it plays in promoting trade and development. The most important of its work products in the field of foreign investment is the 1976 Guidelines for Multinational Enterprises, revised in 2000. ORGANIZATION FOR ECONOMIC COOPERATION AND DEvelopment, THE OECD DEClaRATION aNd DECISIONS ON INTERNATIONAL INVESTMENT AND MULTINATIONAL ENTERPRISES: BASIC TEXTS, DAFFE/IME(2000)20 (2000). See also WTO Working Group on the Relationship Between Trade and Investment, Communication from the OECD, The OECD Guidelines for Multinational Enterprises, WT/WGTI/W/40 (June 11, 1998) (providing guidelines to OECD member nations); WTO Working Group on the Relationship Between Trade and Investment, Communication from the OECD, Revised OECD Guidelines for Multinational Enterprises, WT/WGTI/W/93 (Oct. 31, 2000) (stating the same); WTO Working Group on the Relationship Between Trade and Investment, Communication from the OECD, Summary of OECD Work on Issues Related to Investment Policy Analysis, WT/WGTI/W/100 (Apr. 2, 2001) (addressing the concerns of FDI); ARGHYRIOS A. FATOUROS, THE OECD GUIDELINES IN A GLOBALISATION WORLD, DAFFE/IME/RD(99)3 (1999) (reconsidering past guidelines); DIRECTORATE FOR FINANCIAL, FISCAL AND ENTERPRISE AFFAIRS, SURVEY OF OECD WORK ON INTERNATIONAL INVESTMENT (Working Paper Series 1998) (summarizing findings on the role of international investment in globalization and economic development).

10 OECD, Open Markets Matter: The Benefits of Trade and Investment Liberalisation 7 (Policy Brief, Oct. 1999). This view is cautiously shared by the United Nations Conference on Trade and Development (UNCTAD), which has served as the focal point in the United Nations system for all matters relating to FDI and multinational corporations. In its World Investment Report 1998, UNCTAD concluded that on balance a multilateral agreement on investment "would improve the enabling environment for FDI, to the extent that it would contribute to greater security for investors and greater stability, predictability and transparency in in- 
The WTO Secretariat has added its support for a multilateral agreement on investment. In a 1996 report, Trade and Foreign Direct Investment, ${ }^{11}$ the Secretariat noted:

At an institutional level, the growing importance of FDI, coupled with the absence of binding multilateral rules on national policies toward FDI, has created what in many quarters is viewed as an obstacle that could slowdown the pace of further integration of the world economy. The perceived need for multilateral rules on investment is not new -indeed, the Havana Charter for the stillborn International Trade Organization ... contained provisions on foreign investment-but attempts to reach a comprehensive multilateral agreement with binding rules have thus far not been successful. ${ }^{12}$

By favoring domestic investors vis-à-vis foreign investors, or by discriminating against foreign investment regardless of country of origin, producers of goods or suppliers of services may be prevented from building or acquiring a facility within a foreign coun-

vestment policies and rules." UNCTAD, WORLD INVESTMENT REPORT 1998: TRENDS AND DETERMINANTS 129 (1998) [hereinafter WORLD INVESTMENT REPORT 1998]. Accord WTO Working Group on the Relationship Between Trade and Investment, Communication from Korea, A Benefit of Multilateral Investment Rules: Enhanced Transparency, at. 1, WT/WGTI/W/70 (Mar. 30, 1999) (stating that "a high level of transparency is crucial"); WTO Working Group on the Relationship Between Trade and Investment, Communication from Japan, Improving Transparency, para. 1, WT/WGTI/W/87 (July 5, 2000) ("Transparency is one of the most important elements."); WTO Working Group on the Relationship Between Trade and Investment, Communication from Hong Kong, China, Transparency of Investment Environment, WT/WGTI/W/90 (Oct. 9, 2000); WTO Working Group on the Relationship Between Trade and Investment, Communication from the European Community and Its Member States, Some Ideas on Flexibility and Non-Discrimination, para. 8, WT/WGTI/W/89 (Oct. 9, 2000) ("[B]e prepared to accept basic rules to increase predictability."). But see UNCTAD, WORLD INVESTMENT REPORT 1996: INVESTMENT, TRADE AND INTERNATIONAL POLICY ARRANGEMENTS 161-63 (1996) (concluding that current bilateral and regional arrangements regulating FDI flows are working well, so that a multilateral agreement on investment may be unnecessary). See generally Hoekman \& Saggi, supra note 8 (concluding that the case for initiating negotiations on investment policies is weak).

11 Press Release, WTO, Report by the WTO Secretariat: Trade and Foreign Direct Investment (Oct. 9, 1996) [hereinafter Trade and Foreign Direct Investment], at http://www.wto.org/english/news_e/pres96_e/pr057_e.htm.

12 Id. 
try due to government barriers to entry of foreign investment capital. As a consequence, local manufacturers or service providers, who may be less efficient than their foreign competitors, will be shielded from foreign competition in the domestic market, reducing total wealth in the target host country. Thus, contend the advocates of an international investment agreement, national laws and regulations that discriminate against foreign direct investment can distort international capital movements in much the same way as tariffs, quotas, and other non-tariff barriers can distort the flow of international trade in goods and services.

Despite the policy arguments for a multilateral agreement on investment, opinion on the issue is divided even among the illuminati. At a special meeting sponsored by the United Nations Conference on Trade and Investment ("UNCTAD") in 1997, some experts on FDI questioned the need for a multilateral agreement on investment, while others supported the idea. ${ }^{13}$ The contentions and assertions in favor of a multilateral agreement on investment beg a host of questions.

First, does the international business community really need a multilateral agreement on investment? Are private investors complaining about a lack of access to foreign markets for their capital because of restrictive foreign investment laws? The answer generally is "no," although anecdotal reports have circulated about performance requirements that an investor has been required to fulfill as a condition to making an investment. ${ }^{14}$ The point is that the

13 See UNCTAD, REPORT OF THE EXPERT MEETING ON EXISTING AGREEMENTS ON INVESTMENT AND THEIR DEVELOPMENT DIMENSIONS (1997), circulated by the Working Group on the Relationship Between Trade and Investment, Communication from UNCTAD, WT/WGTI/W/21 (Jan. 6, 1998) (discussing the advantages and disadvantages to a multilateral agreement).

14 But see Canadian Chamber of Commerce, Foreign Investment Barriers 16 (2000) (reporting the results of a questionnaire to seventy-one Canadian companies that identified 106 specific restrictions faced by these companies when making a foreign investment, which in twenty-one percent of the cases led to a cancellation of the investment), at http://strategis.ic.gc.ca/pics/bi/ barriers.pdf.

In its annual National Trade Estimate Report, the Office of the U.S. Trade Representative reports on foreign barriers to trade in goods and services as well as investment. See, e.g., U.S. TRADE REPRESENTATIVE, 2002 NATIONAL TRADE ESTIMATE REPORT ON FOREIGN TRADE BARRIERS (2002). In the main, these annual Reports discuss trading partners' national barriers to investment but do not indicate that any U.S. investor has specifically complained about the investment barrier, nor do they identify specific complaints by U.S. investors who have been frustrated in their attempt to make a foreign investment as a result of the spotlighted barrier. 
level and type of barriers to investment apparently have not been sufficiently serious that foreign investors have felt motivated to collectively urge their governments to negotiate an international agreement on investment. Why hasn't there been a groundswell of support for a multilateral agreement on investment within the business community? One possible explanation for the apparent lack of interest among the business community is that the demand for foreign capital exceeds its supply, leaving foreign investors with alternative locations for investment. ${ }^{15}$ The general absence of complaints from the investment community might well suggest that the current legal regime governing FDI is not broken. It would also help to explain why the private sector has not led the charge for a multilateral agreement to liberalize FDI because, namely, it has no economic incentive to do so because market access for foreign capital is generally good. ${ }^{16}$ As is explained more fully below, the pace of FDI has only quickened in the past decade, not slowed, despite the absence of a multilateral agreement on in-

In addition, a survey of the petitions filed with the U.S. Trade Representative ("USTR") under Section 301 of the Trade Act of 1974, 19 U.S.C. \$ 2411 (2002), shows that only one petitioner has complained about barriers to foreign investment. On June 16, 1989, the USTR initiated an investigation of trade-restricting measures imposed by the government of India on foreign investors. In two other instances, the USTR self-initiated investigations in cases that were investmentrelated. On October 11, 1996, the USTR self-initiated an investigation under Section 301 with respect to certain acts, policies, and practices of the government of Brazil concerning the grant of tariff-reduction benefits contingent on satisfying certain export performance and domestic content requirements. On October 8, 1996, the USTR self-initiated an investigation under Section 301 with respect to certain acts, policies and practices of the government of Indonesia concerning the grant of conditional tax and tariff benefits intended to develop a motor vehicle sector in Indonesia.

A table of the 121 Section 301 cases initiated by the U.S. Trade Representative, summarizing each of the cases, is available at http://www.ustr.gov $/ \mathrm{html} / \mathrm{act} 301 . \mathrm{htm}$ (last visited Jan. 20, 2003). A table of the twenty-nine withdrawn or rejected Section 301 petitions is available at http://www.ustr.gov $/ \mathrm{html} /$ in 301.htm (last visited Jan. 20, 2003). For an extensive analysis of Section 301, see BHALA \& KENNEDY, supra note 3, at 1009-68.

15 See Trade and Foreign Direct Investment, supra note 11, at 21 (noting the occurrence of competition for foreign direct investment).

16 See Pierre Sauve \& Christopher Wilkie, Exploring Approaches to Investment Liberalization in the GATS 6 (unpublished paper presented at the conference, Services 2000-New Directions in Services Trade Liberalization, cosponsored by the American Enterprise Institute, the Brookings Institution, the Center for Business and Government at Harvard University, and the Coalition of Service Industries Education and Research Foundation, Washington, D.C., June 12,1999 ) (on file with author) (contending there has been no major "market or policy failure" to incentivize a push for FDI liberalization). 
vestment. From 1992 to 2001 , the only year in which FDI declined was 2001, which made sense following the global recession and the aftershock of the September 11 terrorist attack. Moreover, despite the WTO Secretariat's characterization that there was a "perceived need for multilateral rules on investment" dating as far back as the late $1940 s,{ }^{17}$ the Havana Charter provisions on FDI were so weak as to amount to a mere exhortation (a point that is discussed more fully below)..$^{18}$ In fact, all negotiations on a multilateral agreement on investment since the Havana Charter have met with failure. ${ }^{19}$

Second, while the rule of law does provide transparency, stability, and predictability, that fact does not necessarily mean that the proper legal instrument for encouraging and promoting such transparency, stability, and predictability in the context of foreign investment has to be international in scope. ${ }^{20}$ What about the vast network of bilateral and regional investment treaties and the role they play in liberalizing the global market for foreign capital? What benefits would be realized from the multilateralization of bilateral investment treaties ("BITs") that don't already exist? Is the push in some circles for a multilateral agreement on investment a solution in search of a problem? In other words, do existing national, bilateral, and regional rules on investment provide adequate access for foreign capital flowing to host countries? A WTO agreement on investment might increase FDI flows by consolidating changes at the national, bilateral, and regional level that have created a more liberal climate for FDI. The numbers substantiate the success of national policies and bilateral and regional agreements on investment. On the other hand, expanding those bilateral and regional efforts to the multilateral level takes negotiators into uncharted waters. As noted by UNCTAD, "the existence of a network of BITs [bilateral investment treaties] cannot be assumed

17 Trade and Foreign Direct Investment, supra note 11 and accompanying text.

18 See infra notes 57-62 and accompanying text (detailing the Havana Charter's lack of thorough treatment of foreign direct investment).

19 See Mina Mashayekhi, Trade-Related Investment Measures, in UNCTAD, A POSITIVE AGENDA FOR DEVELOPING COUNTRIES: ISSUES FOR FUTURE TRADE NEGOTIATIONS 235 (2000) (discussing how none of the negotiations since the Havana Charter have succeeded).

20 But see WTO Working Group on the Relationship Between Trade and Investment, Communication from Canada, at 3, WT/WGTI/W/36 (Apr. 8, 1998) ("A comprehensive set of consistent rules among all WTO Members would allow for a stable, transparent and consistent environment for firms operating in the global market, whatever their ownership structure or place of incorporation."). 
to signal the preparedness of countries to move to another level, in spite of a convergence of perspectives in certain substantive areas as signified by existing BITs." 21 As UNCTAD notes, there has already been significant liberalization for FDI in many countries, such that any multilateral agreement that prohibits the introduction of new barriers to FDI would essentially maintain the status quo. ${ }^{22}$ An agreement on investment could thus conceivably have little or no impact on FDI flows because it would not materially change the policy and legal framework for FDI that presently exists at the national level. If the economic benefits of foreign investment for a host country are so strong and compelling (a point explored more fully below), ${ }^{23}$ then host countries will have a strong incentive to enact national laws to attract such investment. The evidence shows that this is exactly what has happened with few, if any, reversals in national policies liberalizing market access for FDI in the past ten to fifteen years. In such a legal environment, an international instrument would in effect be mere surplus. The absence of a multilateral agreement on investment has not hobbled FDI flows. In addition, as the paramount international institution for liberalizing cross-border trade in goods and services, some have questioned whether the WTO could successfully address investment issues in an institutional framework that is focused on the movement of goods and services, rather than capital. ${ }^{24}$ Indeed, if a country pursues a policy of open trade in goods and services, then an investment agreement will have marginal impact for those foreign firms that can then access the foreign market through trade rather than investment. ${ }^{25}$ MAI].

21 UNCTAD, LESSONS FROM THE MAI 28 (1999) [hereinafter LESSONS FROM THE

22. See WORLD INVESTMENT REPORT 1998, supra note 10, at 129 (explaining that the maintenance of the status quo is one of several possible impacts of a multilateral framework on investment).

23 See infra notes $259-73$ and accompanying text (explaining why the host country's benefits are significant).

${ }_{24}$ See, e.g., Anyuan Yuan, China's Entry into the WTO: Impact on China's Regulating Regime of Foreign Direct Investment, 35 INT'L LAW. 195, 201 (2001) (discussing whether the WTO can successfully address investment issues).

25 See Hoekman \& Saggi, supra note 8, at 9 (explaining that this is the result because "the realization of profit-shifting objectives requires trade policy instruments"). However, in the case of certain services that are not tradeable across borders, FDI takes on added importance. This additional importance of FDI highlights the significance of pursuing negotiations under the GATS to expand market liberalization, especially under the commercial presence model of supply. 
Third, what about national sovereignty concerns voiced by developing countries insofar as their ability to regulate the activities of foreign investors? What challenges to national labor standards are posed by a multilateral agreement on investment? If the WTO members did negotiate an agreement on investment, what would be the interface between such an agreement and national competition (antitrust) laws? Can there be a WTO agreement on investment without a parallel WTO agreement on competition law and policy? Developing countries, fearing the power of multinational enterprises ("MNE") to crush local competition, have answered "no" in response to this last question. As between developed countries, if a proposed acquisition of a firm by a foreign MNE is rejected by national-competition law enforcement authorities in the $\mathrm{EU}$, for example, on the ground that the acquisition or merger would be anti-competitive, would such action be grounds for a challenge under a WTO investment agreement?

Fourth, what are the lessons to be learned from the failure of the OECD to conclude a multilateral agreement on investment in 1998? Efforts to liberalize international investment have a long history within the OECD, reflected primarily in its non-binding Code of Liberalization of Capital Movements. These efforts were the source of investment principles in subsequent trade agreements, including the North American Free Trade Agreement ("NAFTA") 26 and the WTO Agreement on Trade-Related Investment Measures (the "TRIMs Agreement"). Given the lack of direction at the time within the WTO regarding a multilateral agreement on investment, OECD ministers voted in 1995 to sponsor negotiations and to conclude a multilateral agreement on investment within two years. Firmly convinced that a multilateral agreement on investment would reduce business uncertainty and improve the flow of investment capital around the world, negotiations within the OECD on the Multilateral Agreement on Investment ("MAI") were launched with a completion date set of May 1997.27 Despite the le-

26 North American Free Trade Agreement, Dec. 15, 1993, reprinted in 1 NORTH AMERICAN FreE TRADE AGREEMENT, TEXTS OF AGREEMENT, IMPLEMENTING Bill, STATEMENT OF ADMINISTRATIVE ACTION, AND REQUIRED SUPPORTING STATEMENTS, H.R. DOC. No. 159, 103d Cong. (1st Sess. 1993) [hereinafter NAFTA STATEMENT OF ADMINISTRATIVE ACTION] (entered into force Jan. 1, 1994).

27 See OECD, REPORT BY THE COMMITTEE ON INTERNATIONAL INVESTMENT AND MULTINATIONAL ENTERPRISES AND THE COMMITTEE ON CAPTTAL MOVEMENTS AND INVISIBLE TRANSACTIONS, A MUlmLATERAL AGREEMENT ON INVESTMENT, 
gal and economic arguments for liberalizing national barriers to FDI, the failure of the OECD to conclude the MAI by 1998 should be a sobering reminder that successfully negotiating a comprehensive multilateral agreement on investment is a supremely difficult task.

The draft MAI's main features included provisions extending most-favored-nation ("MFN") and national treatment to both the establishment and the subsequent treatment of an investment; a broad, asset-based definition of investment; standstill and rollback provisions; provisions on country-specific reservations; standards on expropriation, compensation in the event of a taking, and repatriation of profits; and binding arbitration in country-to-country and investor-to-host country disputes. ${ }^{28}$ The final product would have been a comprehensive set of investment rules that would have overlapped with the multilateral trade agreements concluded during the Uruguay Round-in particular, the TRIMs Agreement-and that would have mirrored many of the features of the U.S. prototype bilateral investment treaty. ${ }^{29}$ The MAI would have

DAFFE/CMIT/CIME (95) 13/FINAL (May 5, 1995), available at http://www1 .oecd.org/daf/mai/htm/cmitcime95.htm.

28 See OECD, ThE MAI Negotiating Text (as of Apr. 24, 1998) [hereinafter MAI NEGOTIATING TEXT] (elaborating on these main features), available at http://www.nadir.org/nadir/initiativ/agp/free/mai/mai.pdf; ORGANIZATION FOR ECONOMIC COOPERATION AND DEVELOPMENT, COMMENTARY TO THE MAI NEGotIATING TEXT (as of Apr. 24, 1998) (explaining OECD's positions on these features of the MAI). For a brief account of the highlights of the main provisions of the MAI and the MAI negotiating process, see LESSONS FROM THE MAI, supra note 21; WORLD INVESTMENT REPORT 1998, supra note 10, at 65-69. See also Michael P. Avramovich, The Protection of International Investment at the Start of the Twenty-First Century: Will Anachronistic Notions of Business Render Irrelevant the OECD's Multilateral Agreement on Investment?, 31 J. MARSHALL L. REv. 1201, 1277 (1998) (arguing in support of concluding negotiations on an MAI); Stephen J. Canner, The Multilateral Agreement on Investment, 31 CORNELL INT'L L.J. 657, 666 (1998) (concluding that an MAI must include provisions on binding dispute settlement, adequate compensation, and compensation that includes the full value of the investor's intangible assets).

29 A U.S. BIT provides U.S. investors with six basic benefits. The new prototype BIT contains the major features of its predecessor. Beginning with a comprehensive definition of direct investment that includes tangible as well as intangible property, a U.S. BIT contains five core elements: (1) national treatment and MFN treatment for investments; (2) standards for expropriation and compensation in the event of a taking; (3) the right to transfer funds; (4) limits on performance requirements consistent with the provisions of NAFTA and the TRIMs Agreement; and (5) a binding dispute settlement mechanism.

The United States launched its BIT program in 1982 in order to secure for U.S. direct investors certain rights and protections overseas. U.S. BITs originally were 
been a free-standing international treaty, open to accession by all countries regardless of whether they were OECD members. ${ }^{30}$

The negotiations ultimately floundered because several highly contentious issues could not be satisfactorily resolved. These issues were the definition of investment, exceptions to national and MFN treatment, intellectual property, a cultural exception proposal by France and Canada, exceptions for regional trade arrangements, exceptions under national treatment, performance requirements, labor and environmental issues, regulatory takings, the extraterritorial application of U.S. laws (in particular, the Helms-Burton Act), and dispute settlement. ${ }^{31}$ In May 1998, the date set for com-

negotiated with developing countries exclusively. See generally Jeswald $W$. Salacuse, BIT by BIT: The Growth of Bilateral Investment Treaties and Their Impact on Foreign Investment in Developing Countries, 24 INT'L LAW. 655 (1990) (detailing the emergence and evolution of U.S. BITs). However, more recently the BITs program has shifted focus to Eastern Europe, the republics of the former Soviet Union, and Latin America.

The U.S. prototype BIT does not differ in its material respects from other countries' standard models for BITs. See WTO Working Group on the Relationship Between Trade and Investment, Communication from Japan, WT/WGTI/W/34 (Apr. 8, 1998) (illustrating standard BIT models); WTO Working Group on the Relationship Between Trade and Investment, Communication from Korea, Korea's Bilateral Investment Treaties, WT/WGTI/W/42 (July 6, 1998) (illustrating standard BIT models); WTO Working Group on the Relationship Between Trade and Investment, Communication from Turkey, Turkey's Experience with Bilateral Investment Treaties, WT/WGTI/W/51 (Sept. 18, 1998) (illustrating standard BIT models).

30 Sovereignty concerns led U.S. state governors to express reservations about the MAI. See WESTERn GOVERNORS' ASSOCIATION, MULTLLATERAL AGREEMENT ON INVESTMENT: POTENTIAL EFFECTS ON STATE \& LOCAL GOVERNMENT 19-21 (1997) (presenting a range of concerns involving how MAI might infringe upon sovereignty), available at http://www.westgov.org/wga/publicat/maiweb.htm. The MAI was at one time considered a possible framework for a WTO agreement on trade and investment by the Clinton Administration. See Tarullo Says MAI May Provide Framework for International Accord, 14 Int'1 Trade Rep. (BNA) 2032 (Nov. 26, 1997). For additional analysis of the MAI, see WORLD INVESTMENT REPORT 1998, supra note 10, at 65-69.

31 See LESSONS FROM THE MAI, supra note 21, at 1; Mashayekhi, supra note 19, at 235 (presenting a failure to resolve these issues). On March 12, 1996, President Clinton signed the Cuban Liberty and Democratic Solidarity (LIBERTAD) Act of 1996, popularly known as the Helms-Burton Act. Cuban Liberty and Democratic Solidarity (LIBERTAD) Act of 1996, 22 U.S.C. \$\$ 6021-6091 (1996). For articles critiquing the Helms-Burton Act, see Brice M. Clagett, Title III of the Helms-Burton Act Is Consistent with International Law, 90 AM. J. INT'L L. 434 (1996); Andreas F. Lowenfeld, Congress and Cuba: The Helms-Burton Act, 90 AM. J. INT'L L. 419 (1996); Jonathan R. Ratchik, Cuban Liberty and the Democratic Solidarity Act of 1995, 11 AM. U. J. INT'L L. \& POL'Y 343 (1996). The Act broadens the U.S. embargo against Cuba: (1) barring U.S. foreign aid to countries that provide assistance to Cuba; (2) authorizing U.S. nationals who had property confiscated by the Cuban government since 1959 to sue foreign companies if they are "trafficking" in the property that 
pletion of negotiations, the MAI negotiations officially entered a "pause" phase. ${ }^{32}$ This action was taken following strong criticism of the proposed text by labor and environmental groups. Some countries participating in the negotiations also expressed concerns about "free riders" who would receive the benefits of other countries' market openings on FDI, but who would not themselves open their markets to FDI. ${ }^{33}$ France's withdrawal from the MAI negotiations in October 1998, on the ground of inadequate protection of cultural industries, sounded the death knell of the MAI.34

Although the OECD MAI would have been open to acceptance by all countries regardless of OECD membership, many developing countries were hostile to the idea in the absence of a complementary set of rules involving restrictive business practices. Some developing countries feared that investment by multinational corporations would result in local monopolies, which in turn can engage in predatory pricing that would drive local competitors out of business. On the other hand, other developing countries welcome so-called "greenfield" investment that brings fresh capital, man-

was expropriated by the Cuban government after the Cuban revolution; and (3) barring the issuance of visas to aliens who, after the effective date of the Act, confiscate, convert, or traffic in property expropriated from a U.S. citizen. The President has the power to suspend for up to six months at a time the implementation of provisions in Title III of the Act that authorize U.S. nationals to bring lawsuits to recover confiscated property if doing so would be in the national interest. Both Presidents Clinton and Bush have suspended the operation of Title III.

For information about the possible impact on BITs between Cuba and several EU member states because of the EU's apparent capitulation to the Helms-Burton Act, see WTO Working Group on the Relationship Between Trade and Investment, Communication from Cuba, WT/WGTI/W/45 (July 20, 1998).

32 Daniel Schwanen, Chilling Out: The MAI Is on Ice but Global Investment Remains Hot, C.D. Howe Institute Commentary 109, at 2 (June 18, 1998), available at http://www.cdhowe.org/pdf/Sch-03.pdf ("The negotiations toward a Multilateral Agreement on Investment ... have officially entered a 'pause' that some observers say could be permanent.").

33 See The Sinking of the MAI, ECONOMIST, Mar. 14, 1998, at $81-82$ (discussing the potential free-rider problem).

34 See Peter T. Muchlinski, The Rise and Fall of the Multilateral Agreement on Investment: Where Now?, 34 INT'L LAW. 1033 (2000) (tracing the history of failed attempts to negotiate an international investment agreement); Lawrence J. Speer, Mulling Failed MAI Process, OECD Debates Future of Investment Liberalization Process, 16 Int'1 Trade Rep. (BNA) 1570 (Sept. 29, 1999); Lawrence J. Speer \& Gary G. Yerkey, France Pulls Out of OECD Talks on Multilateral Investment Treaty, 15 Int'1 Trade Rep. (BNA) 1750 (Oct. 21, 1998) (discussing France's withdrawal from the negotiations when guarantees on labor and environment standards and a cultural exception were not forthcoming). 
agement know-how, and export markets to the host country. ${ }^{35}$ In the end, of course, it was the OECD members themselves who spiked the draft Agreement. At the risk of placing too much blame on any one country, France had strong reservations about the negative impact a MAI would have on its cultural industries, a misapprehension undoubtedly shared by Canada. ${ }^{36}$ Other OECD members were pressured by domestic environmental groups that pressed their case against the MAI as being a threat to the global environment. In addition, labor advocacy groups wondered how a MAI might negatively affect developing-country labor markets by developed-country multinational investors. The upshot was that by late 1998 the OECD MAI was a dead letter, notwithstanding the great expectations shared by most participants in the negotiations that a successful conclusion was barely weeks away.

Fifth, and finally, what are the lessons to be learned from the pace of liberalization efforts achieved to date under two existing WTO agreements that address key dimensions of FDI: the General Agreement on Trade in Services ("GATS"), including the two subsidiary agreements on financial services and basic telecommunications, and the TRIMs Agreement?

Against this backdrop, the overarching issue addressed in this Article is whether international trade in goods and services should be integrated with foreign direct investment through a WTO agreement on investment. The arguments advanced for such an agreement have an undeniable appeal as a theoretical matter. Proponents of a multilateral agreement on investment - the "globalization school" 17 - submit that national laws and regulations that discriminate against foreign direct investment distort international trade in much the same way as do tariffs, quotas, and other nontariff barriers to trade. By eliminating such laws that either dis-

35 See, e.8., James Lim, South Korea Installs Ombudsman to Resolve Problems of Foreign Investors, 16 Int'l Trade Rep. (BNA) 1792 (Nov. 3, 1999); James Lim, South Korea Says It Will Continue Promotion of Foreign Direct Investment, 16 Int'l Trade Rep. (BNA) 1468 (Sept. 15, 1999); James Lim, South Korea Sets Long-Term Target to Increase Foreign Direct Investment, 17 Int'l Trade Rep. (BNA) 390 (Mar. 9, 2000); Shai Oster, China Looking to Private Investment for Economic Stimulus, Analysts Say, 17 Int'l Trade Rep. (BNA) 45 (Jan. 13, 2000).

36 See Daniel Pruzin, Canada Seeks Support of Trade Partners for Multilateral Accord to Protect Culture, 16 Int'1 Trade Rep. (BNA) 1736 (Oct. 27, 1999) (noting Canada's concern for cultural protection).

37 WTO Working Group on the Relationship Between Trade and Investment, Communication from Korea, Multilateral Framework on Investment: A Realistic Approach, para. 1, WT/WGTI/W/79 (June 2, 1999). 
criminate in favor of domestic investors or that discriminate against foreign investors, the most efficient producers of goods and suppliers of services with capital to invest, regardless of country of origin, will be able to penetrate a market unhindered by government interference.

But just how prevalent are national laws that impede or block the flow of foreign capital? Empirical research on the subject is scant. One study in the mid-1990s of the investment policies of the twenty-nine members of the OECD-whose investment policies might be expected to be the most liberal in the world-revealed that they collectively maintain over 400 investment restrictions. ${ }^{38}$ The fifteen member-states of the EU as a group were reported to have the greatest number of investment restrictions, accounting for $54 \%$ of all restrictions identified for OECD members. The United States was reported to have the second largest number of restrictions, accounting for $17 \%$ of the OECD total, followed by Canada, Mexico, and Australia with $14 \%, 7 \%$, and $6 \%$, respectively. ${ }^{39}$ However, as is discussed below, the decided trend in the latter half of the 1990 s and into the 21 st century has been to enact regulatory

38 See Liberalization of International Investment, supra note 5, at 8.

39 Id. A proposed purchase in 1988 of an eighty percent interest in an American firm, Fairchild Semiconductor Corp., by a Japanese firm, Fujitsu, Ltd., was the catalyst for a provision added to the Omnibus Trade and Competitiveness Act of 1988 to amend the Defense Production Act of 1950. The new provision, commonly known as the Exon-Florio amendment, authorizes the President to review and prohibit the acquisition, merger, or takeover of a business in the United States by a foreign person if such commercial activity could result in foreign control of a U.S. firm that would threaten to impair national security. See Defense Production Act $\S 721$ (1950), as amended by the Omnibus Trade and Competitiveness Act of 1988, codified at 50 U.S.C. $\$ 2170$.

In exercising his authority under Exon-Florio, the President is directed to consider such factors as domestic production needed for projected national defense requirements and the capacity of domestic industries to meet national defense requirements. The 1992 Byrd-Exon amendment required an investigation whenever an attempted purchase is made by an entity owned or controlled by a foreign government. See 50 U.S.C. $\$ 2170$ (c). The Byrd-Exon amendment was in direct response to an unsuccessful bid by Thomson-CSF, a French company partially owned by the French government, to purchase the missile division of LTV Corp., a U.S. aerospace company. See generally Patrick L. Schmidt, The Exon-Florio Statute: How It Affects Foreign Investors and Lenders in the United States, 27 INT'L LAW. 795 (1993).

Pursuant to Executive Order, the Exon-Florio amendment is enforced by the interagency Committee on Foreign Investment. See Exec. Order No. 12,661, 54 Fed. Reg. 779 (Dec. 27, 1988). It has been the target of heavy criticism from the EU. See More U.S. Barriers to Trade with EU Arose in Past Year, EU Report Says, 13 Int'1 Trade Rep. (BNA) 1244 (July 31, 1996). 
measures that are hospitable to FDI. Moreover, despite these restrictions and the absence of a multilateral agreement on investment, investors' appetite for making investments abroad has only grown. 40 Oddly enough, there appears to be an inverse correlation between the number of restrictions on FDI and FDI flows. During the ten-year period from 1992 to 2001, the top sixteen recipients of FDI were OECD members. Of all OECD member countries, the United States had the largest number of restrictions on FDI in the 1990s, as reported by the OECD, yet the United States received more FDI inflows in the period 1992-2001 than any other country, $\$ 1.27$ trillion, more than double the numbers of second-place Britain. ${ }^{11}$ Similarly, even though China places numerous restrictions on investment, it remains one of the world's top destinations for foreign direct investment. ${ }^{42}$

A counterpoint to the globalization school of FDI is the "internalization school." The internalization school believes in minimizing the amount of outside intervention in a country's ability to establish national laws and regulations governing FDI, thus reserving the maximum flexibility of host countries to deal with FDI. ${ }^{43}$

Before examining in-depth the pros and cons of a WTO agreement on investment, a survey of the history of investment rules within the GATT-WTO legal regime, including the Uruguay Round and post-Uruguay Round results, will provide important background and perspective. The following survey will show that WTO addresses the subject of foreign direct investment in several

40 See Patrick Tracey, Foreign Direct Investors See Increase; China, Others Gain Investment Appeal, 18 Int'l Trade Rep. (BNA) 306 (Feb. 22, 2001).

41 Economic and Financial Indicators, ECONOMIST, Aug. 17, 2002, at 77.

42 Yuan, supra note 24, at 201. The four leading host countries for FDI inflows during the decade $1985-95$ were the United States ( $\$ 478$ billion), the United Kingdom ( $\$ 200$ billion), France ( $\$ 138$ billion), and China ( $\$ 130$ billion). Trade and Foreign Direct Investment, supra note 11, at 5 . In 1997, the United States $(\$ 76.5$ billion), China ( $\$ 40.8$ billion), the United Kingdom ( $\$ 26$ billion), and France ( $\$ 22$ billion) were the top four recipients of FDI inflows. WORLD INVESTMENT REPORT 1998, supra note 10, tbl.I.9. In 1999, the United Kingdom surpassed the United States as the largest outbound investor for the first time since 1988, although the United States remained the leading recipient of FDI (over $\$ 250$ billion) by a factor of nearly three over second-place Sweden (approximately $\$ 75$ billion). Economic and Financial Indicators, ECONOMIST, Feb. 12, 2000, at 105.

43 WTO Working Group on the Relationship Between Trade and Investment, Communication from Korea, Multilateral Framework on Investment: A Realistic Approach, para. 2, WT/WGTI/W/79 (June 2, 1999). More will be said about the views and arguments of the internalization school as this Article unfolds. 
important respects. When it comes to investment, the WTO is not operating in a complete vacuum.

\section{INVESTMENT RULES IN THE GATT-WTOSYSTEM}

Over its fifty-five year history, the GATT-WTO international trading system has had as its core goal the elimination of government barriers to international trade in goods and now, under the GATS, the creation of market access for services as well. Although nowhere explicitly stated in the General Agreement on Tariffs and Trade ("GATT") or any WTO agreement, the guiding economic premise that underlies the entire GATT-WTO system is open trade. One commentator has explained open trade (sometimes referred to as liberal trade) in the following terms:

In a liberal economic system, government does not thwart private parties in their attempts to enter voluntary transactions, and taxes are stable, predictable, and nonprohibitive. The General Agreement on Tariffs and Trade (GATT) is liberal in this sense.... Interventions [by governments] in liberal exchange across frontiers to make trade fair may be the political price of liberalism, but such interventions are themselves its antithesis. ${ }^{44}$

Why did open trade become GATT's desideratum? The answer is short but compelling: by exploiting the law of comparative advantage, liberal trade policies permit the unrestricted flow of the best goods and services across national borders at the lowest prices, thereby increasing total world wealth. Under the law of comparative advantage, resources are allocated efficiently across and within industries in response to competitive pressures from imports. Both of these phenomena lead to product specialization and increased firm size that in turn lowers the unit cost of goods and services. The role that multilateral trade rules play in fostering liberal trade manifests itself in two important ways. First, specialization and economies of scale become possible because of secure access to a barrier-free international market. Second, increased in-

44 Martin Wolf, Why Trade Liberalization Is a Good Idea, in THE URUGUAY Round: A HaNDBOOK ON THE Multilateral Trade Negotiations 14 (J. Michael Finger \& Andrzej Olechowski eds., 1987). 
ternational competition leads to product and process innovation, further reducing costs and expanding consumer choices. 45

The kinds of government conduct restricting market access that have been of greatest interest to the GATT contracting parties, and today, to the WTO members, include reducing and eliminating tariffs on imported goods, limiting the use of import and export quotas, imposing discipline on the imposition of safeguard measures (i.e., escape clause relief), ensuring that state-trading enterprises that have a monopoly on the purchase and/or sale of goods conduct their operations on the basis of market disciplines, circumscribing the use of antidumping duties, discouraging subsidies to sunset and sunrise domestic industries, and limiting the extent to which governments can restrict imported goods on the basis of product standards. All of these trade liberalization measures can have the salutary effect of indirectly combating certain restrictive business practices engaged in by domestic firms, e.g., price fixing, by allowing greater import competition that will in turn break up such illegal arrangements through price competition. The GATTWTO system has had little or nothing to say about private restrictive business practices, government-sponsored commodity cartels (e.g., the Organization of Petroleum Exporting Countries "OPEC"), government-sponsored boycotts, and government procurement laws that discriminate in favor of domestic suppliers. ${ }^{46}$ Until the Uruguay Round, the same was true for national laws that discriminate against, restrict, or otherwise distort the global market for foreign direct investment.

45 For classical and contemporary arguments in support of free trade and the arguments for protectionism, see RAJ BHALA, INTERNATIONAL TRADE LAW: THEORY AND PRACTICE 1-123 (2001); Richard B. Stewart, International Trade and Environment: Lessons from the Federal Experience, 49 WASH. \& LEE L. REV. 1329, 1330 (1992); The Miracle of Trade, ECONOMIST, Jan. 27, 1996, at 61-62.

46 The plurilateral Agreement on Government Procurement opens government procurement of goods, services, and construction contracts to enterprises from the other signatories to the Agreement. See Agreement on Government Procurement, Apr. 15, 1994, available at http://www.wto.org/english/tratop_e /gproc_e/agrmnt_e.htm. (last visited on Jan. 31, 2003). To date, twenty-seven countries and the European Communities are parties to the Government Procurement Agreement, with seven countries involved in accession negotiations. An updated list of countries that are party to the Agreement on Government Procurement is available at http://www.wto.org/english/tratop_e/gproc_e /memobs_e.htm. (last visited Jan. 31, 2003). 


\subsection{The Havana Charter and GATT 1947}

The World Trade Organization traces its origins to 1944. In that year, a comprehensive economic and financial plan for postWorld War II reconstruction and development was proposed by the United States and the United Kingdom at Bretton Woods, New Hampshire. A triad of international economic and financial institutions was envisioned. Two of the institutions, the World Bank and the International Monetary Fund ("IMF"), were created to address development and monetary issues. Rounding out the institutional triad was the International Trade Organization ("ITO"). The General Agreement was to serve as an interim agreement until the ITO and its founding document, the Havana Charter, could be approved by national legislatures. ${ }^{47}$

In September 1946, the United States drafted a proposed Charter that became the basis for discussions at the First Session of the Preparatory Committee on the Havana Charter. ${ }^{48}$ During the period 1946-1947, the Preparatory Committee began drafting the ITO Charter. Independent of this project, the Committee members also conducted tariff-reduction negotiations in anticipation of the completion of the ITO Charter. They negotiated approximately 45,000 tariff concessions affecting about $\$ 10$ billion of world trade in goods. ${ }^{49}$ In order to protect the value of these concessions, the Committee members further agreed to the early acceptance of

47 For a complete history of GATT and the Bretton Woods system, see KENNETH W. DAM, THE GATT: LAW AND INTERNATIONAL ECONOMIC ORGANIZATION (1970); ROBERT E. HUDEC, THE GATT LEGAL SYSTEM AND WORLD TRADE DIPLOMACY (2d ed. 1990); JOHN H. JACKSON, WORLD TRADE AND THE LAW OF GATT (1969); G.J. LANJOUW, INTERNATIONAL TRADE INSTITUTIONS (ACE Translations trans., 1995); OLIVIER LONG, LAW AND ITS LIMITATIONS IN THE GATT MULTILATERAL TRADE SYSTEM 4-6 (1985); ARMAND VAN DORMAEL, BRETTON WOODS: BIRTH OF A MONETARY SYSTEM (1978); Gerald A. Bunting, GATT and the Evolution of the Global Trade System: A Historical Perspective, 11 ST. JoHN's J. LEGAL COMMENT. 505 (1996).

48 The members of the Preparatory Committee were Australia, Belgium, Luxembourg, Brazil, Canada, Chile, China, Cuba, Czechoslovakia, France, India, Lebanon, the Netherlands, New Zealand, Norway, South Africa, the U.S.S.R., the United Kingdom, and the United States. With the exception of the former Soviet Union, all of these countries became GATT contracting parties under Protocols of Provisional Application. See WTO, 1 ANALYTICAL INDEX: GuIDE TO GATT LAW AND PRACTICE, at 1-9 (1995).

For additional background on the preparatory work on GATT, see DAM, supra note 47, at 10-16; JACKSON, supra note 47, at 35-57; LONG, supra note 47, at 4-6; Armin von Bogdandy, The International Trade Law, in U.S. TRADE BARRIERS: A LEGAL ANALYSIS 73, 74-76 (Eberhard Grabitz \& Armin von Bogdandy eds., 1991).

49 BHALA, supra note 45 , at 127-28, 133. 
some of the obligations in the draft ITO Charter. The combination of the tariff concessions and interim trade rules was formalized in the GATT. In short, in order to expedite the start of international negotiations on tariff reductions and their implementation pending approval of the Havana Charter by national legislatures, GATT was approved provisionally by national representatives, effective January 1, 1948.50 President Truman approved it on behalf of the United States pursuant to authority granted under the Reciprocal Trade Agreements Act of 1934. ${ }^{51}$

GATT Article XXIX makes it plain that GATT was not intended by its drafters to function on a permanent basis. It was contemplated that once the Havana Charter entered into force, and with it the ITO, Part II of GATT that contains the bulk of the international legal commitments (other than the MFN obligation and tariff commitments) would be suspended. ${ }^{52}$

In the end, the Havana Charter never entered into force. In fact, no acceptances of the Charter were ever received by the United Nations, the depositary for Charter accessions. ${ }^{53}$ The Havana Charter was a far more comprehensive document than GATT. It contained provisions relating to employment, economic development, restrictive business practices, and dispute resolution under ITO auspices. ${ }^{54} \mathrm{Had}$ it been approved, the Havana Charter for

50 Id. at $127-28$.

51 Id. at 128.

52 See General Agreement on Tariffs and Trade, art. XXIX, opened for signature Oct. 30, 1947, 61 Stat. pts. 5, 6, T.I.A.S. No. 1700, 55 U.N.T.S. 187 [hereinafter 1947 GATT]. GATT Article XXIX provides that Part II of the Agreement shall be suspended on the day on which the Havana Charter enters into force. In addition, it provides that if by September 30,1949, the Havana Charter has not entered into force, the contracting parties shall meet before December 31, 1949, to agree whether the Agreement shall be amended, supplemented or maintained.

53 See BHALA \& KENNEDY, supra note 3, at 2.

Once it became clear that the Havana Charter had no chance of being approved by the neo-isolationist U.S. Senate, the State Department issued a statement that the Charter would not be submitted again to Congress. As a consequence, GATT was pressed into service by default to fill the institutional vacuum. Despite its left-footed start, GATT became the centerpiece of international trade law, doubling as a multilateral trade agreement and an international trade forum for its 114 contracting parties for nearly five decades.

Id.

54 Final Act and Related Documents of the United Nations Conference on Trade and Employment, Havana, Cuba, Mar. 24, 1948, U.N. Doc. ICITO/1/4 
an International Trade Organization would have covered not only tariffs, quotas, and other non-tariff barriers to trade in goods, but also restrictive business practices (Articles 46-54), 55 commodity agreements (Articles 55-70), ${ }^{56}$ and foreign direct investment (Articles $11 \& 12) .{ }^{57}$ Although the refusal of national legislatures -in particular, the neo-isolationist U.S. Senate - to approve the Havana Charter could be viewed quite naturally as a missed opportunity, it is debatable whether the Charter would have thrown open the gates to FDI. The Havana Charter's coverage of foreign direct investment is, at best, skeletal. In fact, far from being a comprehensive code analogous to today's typical bilateral investment treaties, Articles 11 and 12 merely sketch out in broad brush the role of the International Trade Organization in promoting FDI, and minimal rights of ITO members which are host countries for FDI.

First, Article 11.2 of the Havana Charter authorized the ITO to enter into collaborative programs with other inter-governmental organizations (e.g., the World Bank and the IMF) that would (1) lead to the conclusion of a bilateral or multilateral agreement on double taxation in order to stimulate foreign investment, and (2) "promote the adoption of a general agreement or statement of principles regarding the conduct, practices and treatment of foreign investment." 58 Article 11 clearly saves for another day the details of a multilateral agreement on investment.

Second, Article 12 of the Havana Charter, entitled International Investment for Economic Development and Reconstruction, is a statement of non-binding principles regarding FDI. Under Article 12.1, members recognize that international investment "can be of great value in promoting economic development and reconstruction, and consequent social progress," and that "the international flow of capital will be stimulated to the extent that Members afford nationals of other countries opportunities for investment and security for existing and future investments." 59 Article 12.1(c) goes on to reserve to members the following rights:

(1948) [hereinafter Havana Charter]. See generally CLAIR WILCOX, A CHARTER FOR WORLD TRADE (1949).

55 Havana Charter, supra note 54, arts. 46-54.

56 Id. arts. 55-70.

57 Id. arts. 11-12.

58 Id. art. 11.2(c).

59 Id. art. 12.1. 
(i) to take any appropriate safeguards necessary to ensure that foreign investment is not used as a basis for interference in its internal affairs or national policies;

(ii) to determine whether and to what extent and upon what terms it will allow future foreign investment;

(iii) to prescribe and give effect on just terms to requirements as to the ownership of existing and future investments;

(iv) to prescribe and give effect to other reasonable requirements with respect to existing and future investments. ${ }^{60}$

What clearly emerges from Article 12(c) is the right to restrict investment to match national development plans. Article 12.1(d) further notes that economic development "may be promoted" if source and host countries enter into bilateral or multilateral investment agreements. ${ }^{61}$ As such, it is more of a suggestion than a legally-binding commitment. Finally, under Article 12.2, members agree that if they do enter into such bilateral or multilateral agreements, they would provide reasonable opportunities for investment on non-discriminatory terms. ${ }^{62}$

In short, considering the Havana Charter's mostly hortatory, and even at that, sparse provisions on FDI, it would be a stretch to conclude that the failure to ratify the Havana Charter had an immediate or lasting negative impact on FDI flows.

Filling the void left by the failure to approve the Havana Charter, and with it, the ITO, was the GATT, the fountainhead of international trade law. ${ }^{63}$ Signed by twenty-three nations - twelve de-

60 Id. art. 12.1(c)(i)-(iv).

61 Id. art. 12.1(d).

62 Id. art. 12.2. 48 , at $4-7$.

631947 GATT, supra note 52; GUIDE TO GATT LAW AND PRACTICE, supra note 
veloped and eleven developing economies - on October 30, 1947, and headquartered in Geneva, Switzerland, GATT 1947 performed double duty for forty-seven years as both the premier multilateral trade agreement and international trade organization. GATT 1947 is the immediate predecessor of GATT 1994 and the WTO, which assumed GATT's dual roles on January 1, 1995, with the successful completion of the Uruguay Round.64

GATT 1947 is virtually silent on the subject of FDI. The question of investment was revisited in the 1955 GATT review conference after it was obvious that the Havana Charter and the ITO were stillborn. That conference recommended that contracting parties take steps to stimulate the international flow of capital, ${ }^{65}$ but nothing concrete ever emerged from that conference.

\subsection{WTO Rules on Investment}

After more than seven years of negotiations, the most farreaching and comprehensive development in world trade since 1947 took place in 1994 with the successful completion of the Uruguay Round of multilateral trade negotiations (the "Round"). Peter Sutherland, the first Director-General of the World Trade Organization, described the conclusion of the Uruguay Round as "a defining moment in modern history." 66 Although the Uruguay

64 Final Act Embodying the Results of the Uruguay Round of Multilateral Trade Negotiations, Apr. 15, 1994, 33 I.L.M. 1143 (1994) [hereinafter Final Act]; EDMOND MCGOVERN, INTERNATIONAL TRADE REGULATION 1.12-3 (1996).

65 Trade and Foreign Direct Investment, supra note 11, at 33-34.

66 Phillip Evans \& James WALSH, THE EIU Guide TO THE NEW GATT 1 (1994). For additional reading on the Uruguay Round summarizing the significant portions of the WTO Agreement, see generally URUGUAY ROUND TRADE AGREEMENTS, STATEMENT OF ADMINISTRATIVE ACTION 1, H.R. DOC. 316, 103d Cong., 656-67 (1994) [hereinafter URUGUAY ROUND STATEMENT OF ADMINISTRATIVE ACTION]; BHALA \& KENNEDY, supra note 3; JOHANNA W. BUURMAN \& JEFFREY J. SCHOTT, THE URUGUAY ROUND: AN ASSESSMENT (1994); JOHN CROOME, RESHAPING THE WORLD TRADING SYSTEM: A HiSTORY OF THE URUGUAY ROUND (1995); JOHN KRAUS, THE GATT NEgOTIATIONS: A BUSINESS GUIDE TO THE RESULTS OF THE URUGUAY ROUND (1994);

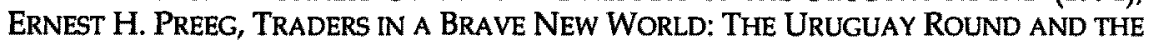
FUTURE OF THE INTERNATIONAL TRADING SYSTEM (1995); THE GATT, THE WTO AND THE URUGUAY ROUND AGREEMENTS ACT: UNDERSTANDING THE FUNDAMENTAL Changes (Harvey M. Applebaum \& Lyn M. Schlitt eds., 1995); THE UruguaY ROUND RESULTS: A EUROPEAN LAWYERS' PERSPECTIVE (Jacques Bourgeois ed., 1994); THE World TRade ORganization: THE Multilateral FramewORK FOR THE 21ST CENTURY AND U.S. IMPLEMENTING LEGISLATION (Terence P. Stewart ed., 1996); John H. Jackson, The Uruguay Round and the Launch of the WTO: Significance \& Challenges, in THE WORLD TRADE ORGANIZATION: THE MULTILATERAL FRAMEWORK FOR THE 21st CENTURY AND U.S. IMPLEMENTING LeGisLATION, supra, at 5; Terence P. 
Round results did not silence the critics of international trade, it did at least lower the volume. The Uruguay Round arrested the slide away from liberal trade and the multilateral rules designed to promote it by renewing the original GATT 1947 commitment to open markets and the elimination of government intervention that impedes trade flows. What is more, the Uruguay Round expanded the multilateral trade system's portfolio by including two new sectors, trade in services and intellectual property ${ }^{67}$

Although the treatment of FDI in the WTO multilateral trade agreements is not comprehensive-no WTO agreement currently exists that creates a framework for the regulation of all aspects of FDI-two WTO multilateral trade agreements ("MTAs"), together with two subsidiary agreements on trade in services, integrate trade and FDI to varying degrees. 68

Stewart, The Uruguay Round Agreements Act: An Overview of Major Issues and Potential Trouble Spots, in THE WORLD TRADE ORganization: THE MulTILATERAL FRAMEWORK FOR THE 21ST CENTURY AND U.S. IMPLEMENTING LEGISLATION, supra, at 29; Terence P. SteWART, THE GATT URUguay Round: A Negotiating History (1986-1992) (1996); Symposium, Negotiating the Free Trade Labyrinth, 18 WHITTIER L. REV. 281 (1997); Symposium, Uruguay Round-GATTMTO, 29 INT'L LAW. 335 (1995).

67 See Agreement on Trade-Related Aspects of Intellectual Property Rights, Apr. 15, 1994, Marrakesh Agreement Establishing the World Trade Organization [hereinafter WTO Agreement], Annex 1C, 33 I.L.M. 1197 (1994) [hereinafter the TRIPS Agreement] (listing contents of "Agreement on Trade-Related Aspects of Intellectual Property Rights").

68 Four other WTO agreements address investment tangentially. First, the TRIPS Agreement is the most comprehensive framework agreement of its kind within the GATT-WTO system. Intellectual property rights are often treated as a form of investment. See General Agreement on Tariffs and Trade: Multilateral Trade Negotiations Final Act Embodying the Results of the Uruguay Round of Trade Negotiations. Apr. 15, 1994, 33 I.L.M. 1125-97 (1994) [hereinafter 1994 GATT] (containing the complete text of the Agreement... Rights). Although the TRIPS Agreement does not address the issue of FDI directly, its provisions on national treatment, MFN, minimum standards of intellectual property protection, and domestic enforcement procedures bear directly on the legal environment in which FDI operates. If a foreign investor cannot place an investment in a host country with the assurance that its intellectual property rights (patents, trademarks, copyrights, etc.) will be adequately protected from infringement, that investor may very well decide not to make the investment. With the minimum protections of the TRIPS Agreement in place for patents, trademarks, copyrights, trade secrets, geographical designations, layout designs of integrated circuits, and industrial designs, coupled with effective mechanisms for the enforcement of those rights against piracy and infringement within the host country, FDI will be encouraged, especially FDI by firms that have valuable intellectual property to protect. The TRIPS Agreement thus serves an important role in promoting investment. See, e.g., Sauvé \& Wilkie, supra note 16, at 14 (discussing the TRIPS Agreements relationship to intellectual property issues). 
First, the GATS is a comprehensive agreement governing all trade in services (with the exception of maritime and air transport services). Second, the 1997 Agreement on Financial Services liberalizes trade and investment in the financial services sector. Third, the 1997 Agreement on Basic Telecommunications likewise liberalizes trade and investment in the basic telecommunications sector. Fourth, the TRIMs Agreement provides a patchwork of rules prohibiting WTO members from requiring both foreign and domestic investors, sourcing inputs locally, imposing trade-balancing requirements on investors as a condition for importing goods or obtaining foreign exchange, restricting access to foreign exchange for the purchase of imports, and restricting the volume or value of exports that a company must make.

These four agreements are analyzed in the following subsections.

Second, the Agreement on Subsidies and Countervailing Measures (the "SCM Agreement") overhauled the comparatively weak Tokyo Round predecessor agreement with tightened and expanded disciplines on the government provision of domestic and export subsidies to domestic producers. The SCM Agreement not only authorizes importing countries to impose countervailing duties on subsidized imports that cause injury, but also goes further by curbing the adverse effects of subsidies in foreign markets. Article 6 of the SCM Agreement makes actionable the provision of subsidies that cause "serious prejudice" to the interests of another member. Annex IV:5 of the SCM Agreement identifies government funds to firms in a "start-up situation" as an example of a subsidy that can give rise to a "serious prejudice" complaint. (A "start-up" situation is one where financial commitments for product development or construction of facilities to manufacture products benefiting from the subsidy have been made, even though production has not begun). See URUGUAY ROUND STATEMENT OF ADMINISTRATIVE ACTION, supra note 66, at 897-941.

Third, Article III:2 of the plurilateral Agreement on Government Procurement provides that procuring entities will not discriminate against locally-established suppliers on the basis of their degree of foreign affiliation or ownership. Agreement on Government Procurement, supra note 46, art. III:2.

Fourth, any FDI-related dispute arising under GATT 1994 or a WTO MTA must be resolved under the provisions of the Dispute Settlement Understanding. See Understanding on Rules and Procedures Governing the Settlement of Disputes, Annex 2, 1994 GATT, supra note 68 , at 1226-47 (containing the complete text of the Understanding on the Rules and Procedures Governing the Settlement of Disputes). This vastly improved, rules-based WTO dispute settlement process will give investors a more certain legal climate within which to make their foreign investment, to the extent a WTO agreement covers the matter in dispute and the investor's home country chooses to espouse the investor's claim. 


\subsubsection{The GATS}

GATT 1947 was almost exclusively concerned with trade in goods. The Uruguay Round's banner achievements include expanding the scope of the GATT-WTO system to include the services sectors. The GATS is a very significant step in establishing an international framework for trade in services, including FDI. ${ }^{69}$

The service sector has overtaken manufacturing as the most important part of developed countries' economies. Service industries account for sixty-one percent of GDP and over one-half of employment in developed countries. ${ }^{70}$ The ratio of exports of world merchandise trade to world services trade was close to three to one in 2001,71 with world trade in commercial services totaling $\$ 1.44$ trillion in 2002 compared to $\$ 4.75$ trillion in merchandise trade. ${ }^{72}$

Given the substantial increase in the volume of services trade, liberalizing trade in services by bringing multilateral disciplines to bear on this sector was an important goal for developed countries in the Uruguay Round. ${ }^{73}$ Developing countries, on the other hand, were unreceptive to the proposal to add services trade to the Uruguay Round agenda. Under the leadership of India and Brazil, they opposed putting services trade on the Uruguay Round agenda at all. ${ }^{74}$ To the extent developed countries enjoy any comparative advantage in this sector, it is in the labor-intensive construction industry; however, restrictive immigration and labor

69 See General Agreement on Trade in Services, Apr. 15, 1994, WTO Agreement, supra note 67, Annex 1C, 33 I.L.M. 1167-96 (1994) [hereinafter the GATS] (containing the complete text of the GATS).

70 The Manufacturing Myth, ECONOMIST, Mar. 19, 1994, at 91 . Jobs in the service sector provide nearly eighty percent of U.S. employment, a figure that is expected to increase to eighty-eight percent by 2005 . Id. Services trade represented more than one quarter of total U.S. exports in 2002. WTO ANNUAL REPORT 2002, at 23-24 (2002). In 2002, U.S. exports of commercial services totaled almost $\$ 263$ billion, representing a global trade surplus in services in 2002 of $\$ 75$ billion. Id. at 24 .

71 WTO ANNUAL REPORT 2002, supra note 70, at 23-24.

72 Id.

73 See EvANS \& WALSH, supra note 66, at 28 (arguing that developed countries enjoy a comparative advantage in the more capital-intensive and highly-skilled service industries, such as telecommunications and financial services).

74 For background on the issues confronting the Uruguay Round negotiators in liberalizing trade in services detailing the conflict between developed and developing countries, see CONGRESSIONAL BUDGET OFFICE, THE GATT NEGOTIATIONS AND U.S. TRADE POLICY 119-30 (1987); EVANS \& WALSH, supra note 66, at 28 (noting the comparative advantages of developed and developing countries). 
laws historically have prevented cross-border trade in such services. More importantly, developed countries showed no interest in changing their trade-restrictive immigration laws. ${ }^{75}$ Ultimately, services trade was added to the Uruguay Round agenda. After resolving some preliminary issues (e.g., the definition and quantification of services trade), ${ }^{76}$ the GATS was successfully concluded.

The GATS is the first multilateral agreement covering trade and investment in the services sector. ${ }^{77}$ It is divided into six parts, consisting of twenty-nine articles and eight annexes. ${ }^{78}$ The GATS is modeled after the GATT in both name and content. The bricks and mortar of the GATS are built on three pillars.

First, the GATS framework agreement proscribes core principles and basic obligations governing trade in services that are applicable to all WTO members. These basic obligations include rules on MFN treatment, national treatment, and transparency. ${ }^{79}$

Second, market access commitments made by WTO members are included in national schedules of commitments that are appended to and made an integral part of the GATS. 80 The members' schedules of market access commitments are analogous to the schedule of tariff concessions that members make under GATT Article II. ${ }^{81}$

75 See EVANS \& WALSH, supra note 66 , at 28 (discussing opposition between developed and developing countries).

76 See id. at 29 (defining trade in services).

7 For additional analyses of the GATS, see generally BHALA \& KENNEDY, supra note 3, at 1242-70; URUGUAY ROUND STATEMENT OF ADMINISTRATIVE ACTION, supra note 66, at 966; U.S. INT'L TRADE COMM'N, GENERAL AGREEMENT ON TRADE IN SERVICES: EXAMINATION OF MAJOR TRADING PARTNERS' SCHEDULES OF COMMITMENTS, USITC Pub. 2940 (Jan. 1996); U.S. INT'L TRADE COMM'N, THE YEAR IN TRADE 1993: OPERATION OF THE TRAde AGREEMENTS Program 19-24, USITC Pub. 2769 (1994); MCGovern, supra note 64, Part D; Bernard Hoekman, Assessing the General Agreement on Trade in Services, in THE URUGUAY ROUND AND THE DEVELOPING ECONOMIES 88 (Will Martin \& L. Alan Winters eds., 1996); Richard B. Self, General Agreement on Trade in Services, in THE WORLD TRADE ORGanization: THE Multilateral TRADE FRAMEWORK FOR THE 21ST CENTURY AND U.S. IMPLEMENTING LEGISLATION 523 (Terence P. Stewart ed., 1996); Mary E. Footer, The International Regulation of Trade in Services Following Completion of the Uruguay Round, 29 INT'L LAW. 453 (1995).

78 GATS, supra note 69 , at 1167-68.

79 See id. arts. II, III \& XVII, at 1169-70, 1180 (listing general obligations and disciplines for MFN treatment and national treatment).

80 Id. art. XVI, at 1179-80.

81 See 1947 GATT, supra note 52, art. II, at 200 (setting forth the concessions required of contracting members). 
Third, the GATS' eight annexes complement the general rules and market access commitments. The Uruguay Round participants recognized that negotiations would have to be continued on certain service sectors if the Uruguay Round was ever going to be concluded. These specific sectors (maritime transport, telecommunications, and financial services) had proven to be major stumbling blocks for the negotiators. Thus, appended to the GATS are several annexes with guidelines and deadlines for future market access negotiations on the maritime transport, financial, and basic telecommunication services sectors. ${ }^{82}$ Market access commitments were successfully negotiated in 1997 for the financial services and basic telecommunication sectors. ${ }^{83}$ Negotiations on maritime transport services were deferred and continue to be deferred..$^{84}$

Part I of the GATS sets out its scope of coverage and defines several key terms (other definitions are provided in GATS Article XXVIII). Under GATS Article I:1, WTO members agree in principle to universal coverage of all trade in commercial services. ${ }^{85}$ No ser-

82 See BHALA \& KENNEDY, supra note 3, at 1244.

83 See infra notes 152-67, 203-35, and accompanying text (detailing negotiations over financial service and basic telecommunication sectors).

84 At the center of the maritime services deadlock is the Jones Act, 46 U.S.C. $\$ 883$ (1988), which preserves certain preferences for the U.S. coastal shipping industry. Although it is generally true that broad exemptions for existing national laws inconsistent with GATT are not permitted, the Jones Act was temporarily exempted from GATT, pursuant to the General Interpretative Note to Annex $1 A$, para. 3(a). See Multilateral Agreement on Trade in Goods, Apr. 15, 1994, WTO Agreement, Annex 1A, 33 I.L.M. 1155 (1994). Paragraph 3(a) of the General Interpretative Note provides in pertinent part:

The provisions of Part II of GATT 1994 shall not apply to measures taken by a Member under specific mandatory legislation, enacted by that Member before it became a contracting party to GATT 1947, that prohibits the use, sale or lease of foreign-built or foreign-reconstructed vessels in commercial applications between points in national waters or the waters of an exclusive economic zone.

Id. at 1155. The WTO Ministerial Conference was to have reviewed this exemption by 1999 and every two years thereafter as long as the exemption remains in force. Id . para. 3(b), at 1155. The WTO General Council initiated the five-year review of the Jones Act exemption in July 1999, and continued to consider this matter at its meetings in October and November 1999, and in February, May, and July 2000. No conclusions could be reached during these discussions. WTO General Council, Minutes of Meeting Held on 7, 8, 11 and 15 December 2000, WT/GC/M/61 (Feb. 7, 2001).

85 GATS Article I:3(b) defines "services" as "any service in any sector except services supplied in the exercise of governmental authority." GATS, supra note 69, at 1169. Article 1:3(c) in turn defines "services supplied in the exercise of governmental authority" as "any service which is supplied neither on a commercial 
vice sector is excluded a priori under the framework agreement. The GATS Annexes do, however, exclude air transport services and reserve for later negotiation specific commitments on maritime transport. ${ }^{86}$

\subsubsection{Modes of Supply.}

GATS Article I:2 defines "trade in services" by the following four "modes of supply," i.e., the way in which services are delivered.

The first mode is the cross-border supply of services "from the territory of one Member into the territory of any other Member." ${ }^{87}$ For example, a securities firm in Country A sells bonds from Country A to consumers in Country B; or an architect from Country A sends design drawings by mail to a client in Country $B$.

The second mode is consumption of services "in the territory of one member to the service consumer of any other Member." 88 For example, a tour company in Country A supplies a service to Country B consumers in Country A; or a student from Country A studies abroad in Country B.

Third, the service supplier of one member supplies services through a "commercial presence in the territory of any other Member." ${ }^{89}$ For example, a bank located in Country A renders banking services through its branch located in Country $\mathrm{B}$; or an advertising firm in Country A establishes an office in Country B to render services to clients located there.

Fourth and finally, the service supplier of one member supplies services "through the presence of natural persons of a Member in the territory of any other Member."90 For example, an architect from a U.S. firm performs on-site design services in Europe; or an accountant from Country A travels to Country B to render accounting services to a client in Country B.

basis, nor in competition with one or more service suppliers [i.e., government monopolies]." Id.

86 GATS, supra note 69, at 1188-89 (containing the text of the Annex on Air Transport Services); $i d$. at 1192 (containing the text of the Annex on Negotiations on Maritime Transport).

87 Id. art. I:2(a), at 1169.

88 Id. art. $\mathrm{I}: 2(\mathrm{~b})$.

89 Id. art. I:2(c).

90 Id. art. I:2(d). 
The first, second, and fourth modes of supply involve the crossborder delivery of services. The third mode of supply involves the sale of services through an affiliate, i.e., the delivery of services by a foreign-owned firm within the territory of another member through facilities or other commercial presence. The commercial presence mode of supply is especially important because it enhances competition for services markets that are necessarily local in their geographic scope and, therefore, immovable. As noted by the United States in a submission to the WTO Working Group on the Relationship Between Trade and Investment, investment under the commercial presence mode of supply can not only supplement open international trade, but it can also introduce or increase competition where open trade has not yet reached.91

The Annex on Article II Exemptions is arguably the most important of the eight annexes appended to the GATS. ${ }^{92}$ Contrary to the rigid, unconditional MFN obligation found in Article I of GATT, GATS Article II introduces some flexibility by authorizing MFN exemptions, 93 provided that the exemption is listed in the

91 See WTO Working Group on the Relationship Between Trade and Investment, Communication from the United States, at 3, WT/WGTI/W/55 (Sept. 25, 1998) (discussing the correlation between free flows of investment and increased competition).

Economically meaningful trade in services, especially under the commercial presence mode of supply, requires that service suppliers and their customers be able to make unimpeded capital transactions across national borders. To that end, GATS Article XI limits the ability of WTO members to restrict international transfers and payments for current transactions relating to specific market access commitments. GATS, supra note 69 , at $1175-76$. Members may restrict such payments and transfers solely in accordance with GATS Article XII on balance-ofpayments restrictions. $I d$. at 1176-77.

92 See id., Annex on Article II Exemptions, at 1187 (containing the Annex on Article II Exemptions).

93 GATS Article II:1 does provide for immediate and unconditional MFN treatment to services and service suppliers of any other WTO member. The phrase "treatment no less favourable" used in GATS Article II:1 has been interpreted as being synonymous with "no less favorable conditions of competition." WTO, Dispute Panel on European Communities, Regime for the Importation, Sale and Distribution of Bananas, para. 7.353, WT/DS27/R/USA (May 22, 1997). There, the panel concluded that the EC's $30 \%$ allocation of available import licenses for bananas at in-quota tariff rates created less favorable conditions of competition for the like-service suppliers from the complaining WTO members (i.e., Ecuador, Guatemala, Honduras, Mexico, and the United States). The allocation was, therefore, inconsistent with GATS Article II. The panel's conclusion was affirmed by the Appellate Body. See WTO Appellate Body, European Communities Regime for the Importation, Sale and Distribution of Bananas, para. 244, WT/DS27/AB/R (Sept. 9, 1997) (affirming the Dispute Panel's conclusion). 
member's Schedule of Commitments and does not extend beyond ten years. ${ }^{94}$ Nevertheless, despite the principle in the Annex that MFN exemptions should not exceed ten years,95 only nine of the 424 listed MFN exemptions specify a duration of ten years. ${ }^{96}$

Seventy-nine of the WTO members (counting the EU as one member) listed MFN exemptions in their schedules of GATS commitments. ${ }^{97}$ Of the 424 exemptions, $35 \%$ are in the transport services sector, $25 \%$ are in the communications sector (primarily in audiovisual services), ${ }^{98} 13 \%$ are in the financial services sector, and

94 See WTO, Compilation of Article II (MFN) Exemptions by Sector, Informal Note by the Secretariat, Job. No. 1551 (Mar. 9, 2000) (specifying the nature of the exemptions). The format that the WTO members use in listing their MFN exemptions contains five items of information: (1) a description of the sector or sectors to which the exemption applies; (2) a description of the measure, indicating why it is inconsistent with Article II; (3) the country or countries to which the measure applies; (4) the intended duration of the exemption; and (5) the conditions creating the need for the exemption. See OECD, Working Party of the Trade Committee, Trade in Services: $A$ Roadmap to GATS MFN Exemptions, at 4-5 n.2, TD/TC/WP(2001)25/FINAL (Oct. 29, 2001) [hereinafter Roadmap] (outlining the five types of information to be provided for each exemption).

95 GATS, supra note 69, Annex on Article II Exemptions, para. 6, at 1187.

96 See Trade in Services: A Roadmap to GATS MFN Exemptions, supra note 94, at 19 ("Only 9 of the 424 exemptions are said to apply for a duration of 10 years."). All unexpired exemptions were reviewed by the Council for Trade in Services in 2000. For a summary and critique of that review, see WTO, Council for Trade in Services, Communication from Hong Kong, China, Japan and Korea, S/C/W/173 (Oct. 6,2000 ) (discussing matters arising from the MFN Exemption Review).

97 See Trade in Services: A Roadmap to GATS MFN Exemptions, supra note 94, at 6 ("The 424 exemptions to Article II of the GATS have been listed by 79 WTO Members (counting the EC as one Member), a majority of the WTO membership."). "[M]ost of those 79 Members have listed 5 exemptions or less, while 10 countries listed more than 10 [exemptions]." Id. Of the Quad members (i.e., Canada, the EC, Japan, and the United States), only Japan did not list any GATS MFN exemptions. See id. at 8 (describing exemptions listed by members).

98 See, e.g., id. at 6 (containing the EC Schedule of Commitments which provides preferences to EC-member states for audiovisual services). An example of an Article II exemption is the one the United States took in the 1997 basic telecommunications negotiations. The exemption was in response to Canada's unwillingness to eliminate its $46.7 \%$ equity cap restriction on foreign ownership of most basic telecom service providers. The exemption provides: 
$18 \%$ apply to all services sectors. 99 Of the various conditions that have prompted the listing of GATS MFN exemptions, $55 \%$ relate to international agreements, while $37 \%$ of the exemptions identify reciprocity as the reason for the exemption. ${ }^{100}$ Almost half of the exemptions that are based on reciprocity have been taken in the transport sector. ${ }^{101}$ Reciprocity accounts for more than $80 \%$ of the exemptions listed for professional services and nearly $50 \%$ for financial services. ${ }^{102}$ For example, the United States has listed MFN exemptions regarding the movement of persons for countries with whom the United States has a friendship, commerce and navigation treaty or a bilateral investment treaty; certain differential taxation measures; and certain aspects of air, road, pipeline, and space transport. ${ }^{103}$

Exemptions are subject to negotiation in subsequent trade liberalizing rounds. 104 Any exemption with a term greater than five years is subject to review by the WTO Council for Trade in Ser-

\section{THE UNITED STATES - LIST OF ARTICLE II (MFN) EXEMPTIONS}

\begin{tabular}{|c|c|c|c|c|}
\hline $\begin{array}{l}\text { Sector or } \\
\text { Subsector }\end{array}$ & $\begin{array}{l}\text { Description of Measure } \\
\text { Indicating Its Inconsis- } \\
\text { tency with Article II }\end{array}$ & $\begin{array}{l}\text { Countries } \\
\text { to Which } \\
\text { the Meas- } \\
\text { ure Applies }\end{array}$ & $\begin{array}{l}\text { Intended } \\
\text { Duration }\end{array}$ & $\begin{array}{l}\text { Conditions } \\
\text { Creating the } \\
\text { Need for the } \\
\text { Exemption }\end{array}$ \\
\hline $\begin{array}{l}\text { Telecommunica- } \\
\text { tion services: } \\
\text { One-way satellite } \\
\text { transmission of } \\
\text { DTH and DBS } \\
\text { television ser- } \\
\text { vices and of digi- } \\
\text { tal audio services }\end{array}$ & $\begin{array}{l}\text { Differential treatment of } \\
\text { countries due to applica- } \\
\text { tion of reciprocity meas- } \\
\text { ures or through } \\
\text { international agree- } \\
\text { ments guaranteeing } \\
\text { market access or na- } \\
\text { tional treatment }\end{array}$ & All & Indefinite & $\begin{array}{l}\text { Need to en- } \\
\text { sure substan- } \\
\text { tially full } \\
\text { market access } \\
\text { and national } \\
\text { treatment in } \\
\text { certain } \\
\text { markets }\end{array}$ \\
\hline
\end{tabular}

WTO, United States, List of Article II (MFN) Exemptions, GATS/EL/90/Suppl.2 (Apr. 11, 1997). The abbreviations "DTH" and "DBS" stand for "direct-to-home" and "direct broadcast satellite," respectively.

99 See Roadmap, supra note 94, at 10 (detailing the sectoral incidence). The balance of the exemptions are in professional services (18), recreation and sports services (5), distribution services (3), construction services (2), health services (1), and tourism services (1). See id. (detailing the sectoral incidence).

100 See id. at 22-24 (listing MFN exceptions by categories and characteristics relating to reciprocity).

$101 \mathrm{Id}$.

102 See id. at 24 (noting that reciprocity accounts for $83 \%$ of professional services and $47 \%$ of financial services).

${ }_{103}$ WTO, United States, Final List of Article II (MFN) Exemptions, at 78-94, GATS/EL/90, (1994), reprinted in U.S. Int'1 Trade Comm'n, U.S. Schedule of Commitments Under the General Agreement on Trade in Services, Inv. No. 332354 (May 1997).

104 GATS, supra note 69, Annex on Article II, para. 6, at 1187. 
vices. ${ }^{105}$ However, the Council has no express authority to demand termination of the exemption. ${ }^{106}$

\subsubsection{Market Access}

If the framework agreement is the skeleton of the GATS, then the schedule of market access commitments is the flesh on the bones. The WTO members' schedules list the service sectors and modes of supply for which individual members have agreed to provide full or partial access to the service suppliers of other WTO members.

In order to harmonize members' schedules, during the Uruguay Round, the GATT Secretariat suggested the use of a Services Sectoral Classification List ("Classification List").107 The Classification List employs 155 service industries, with four possible modes of supply for each industry and with each mode of supply subject to both market access and national treatment commitments. ${ }^{108}$

105 Id. Annex on Article II Exemptions, para. 3, at 1187. authority).

106 Id. Annex on Article II Exemptions, para. 4, at 1187 (limiting the Council's

107 The Services Sectoral Classification List classifies services into the following twelve sectors (which is further divided into 155 subsectors):

1. Business (six subsectors, including professional services)

2. Communication (five subsectors, including telecommunication services)

3. Construction and Related Engineering (five subsectors)

4. Distribution (five subsectors, including wholesale, retail, and franchising)

5. Education (five subsectors)

6. Environment (four subsectors)

7. Financial (three subsectors)

8. Health and Social Services (four subsectors)

9. Tourism and Travel (four subsectors)

10. Recreational, Cultural, and Sporting (five subsectors)

11. Transport (nine subsectors)

12. Other Services Not Included Elsewhere

The GATS classification system has been criticized by more than one source for lacking clarity. See, e.g., Mina Mashayekhi, GATS 2000: Progressive Liberalization, in UNCTAD, A POSITIVE AGENDA FOR DEVELOPING COUNTRIES: Issues FOR FUTURE Trade Negotiations 169, 187 (2000); Mark Felsenthal, GATS Classification Called Unclear; Film Industry Urges Broader Application, 14 Int'l Trade Rep. (BNA) 585 (Apr. 2, 1997).

108 See BHALA \& KENNEDY, supra note 3, at 1262-63 (describing Classification list). The following table is an illustration of the format of members' schedules of commitments: 
Thus, with more than 100 Round participants negotiating bilaterally on a request/offer basis for market access to 1240 service "cells" on a MFN and national treatment basis, the services trade negotiations were, not surprisingly, protracted. ${ }^{109}$

Some Round participants wanted to schedule market access commitments on the basis of a positive list approach. Unless the service sector or mode of supply is expressly listed in a member's schedule of commitments, it is not covered under the GATS. Other participants wanted to proceed on the basis of a negative list approach. Market access would exist for all sectors and modes of supply on a national treatment basis unless express reservations were made in the member's schedule of commitments. The specific commitments made under the GATS are a blend of these two approaches. Only those industries that are listed in a member's schedule of commitments are open to foreign service suppliers with respect to at least one mode of supply (i.e., a positive list approach). ${ }^{110}$ However, if a member has made a commitment, only the conditions, limitations, or qualifications on market access and national treatment listed in the schedule may be imposed (i.e., a negative list approach). ${ }^{111}$ Thus, all schedules must specify (1) terms, limitations, and conditions on market access; (2) conditions and qualifications on national treatment; (3) undertakings relating to additional commitments; (4) the time frame for implementation of commitments; and (5) the date of entry into force of commitments. ${ }^{112}$ Measures that are inconsistent with both Article XVI (market access) and Article XVII (national treatment) are to be inscribed in the column relating to market access limitations, in

[MEMBER'S NAME]-SCHEDULE OF SPECIFIC COMMITMENTS

Modes of supply: (1) Cross-border supply; (2) Consumption abroad; (3) Commercial presence; and (4) Presence of natural persons.

\begin{tabular}{|l|l|l|l|}
\hline $\begin{array}{l}\text { Sector or } \\
\text { Subsector }\end{array}$ & $\begin{array}{l}\text { Limitations on } \\
\text { Market Access }\end{array}$ & $\begin{array}{l}\text { Limitations on Na- } \\
\text { tional Treatment }\end{array}$ & $\begin{array}{l}\text { Additional } \\
\text { Commitments }\end{array}$ \\
\hline & & & \\
\hline
\end{tabular}

The WTO has prepared a Guide to Reading the GATS Schedules of Specific Commitments and the Lists of Article II (MFN) Exemptions, available at http://www.wto .org/english/tratop_e/serv_e/guide1_e.htm. This matrix equals 1240 service "cells" for which market access commitments were requested.

109 BHALA \& KENNEDY, supra note 3, at 1256.

110 See TRIPS, supra note 67, art. XVI:1, at 1179 (laying out both the positive and negative list approaches).

111 Id.

112 See id. art. XX:1, at 1181 (listing the specifications of the schedules). 
which case the inscription will be considered a condition or qualification on national treatment as well.113

Developed countries made market access commitments on approximately $45 \%$ of their service sectors. 114 Developing countries as a group made commitments on only $12 \%$. Starting with 620 as the maximum number of service sectors, subsectors, and modes of supply on which commitments could have been made, the United States made 384 commitments; the EU, 392; Canada, 352; Japan, 408; and Mexico, 252.115 For all service sectors, only 25\% are scheduled by developed countries without conditions or qualifications. ${ }^{116}$ The comparable figure for developing countries is $7 \% .117$

If a member does make market access commitments, and unless a reservation is otherwise recorded in a member's schedule of commitments, then full market access and national treatment is required. ${ }^{118} \mathrm{~A}$ member is prohibited from maintaining or adopting several types of limitations or measures, unless it has otherwise so specified in its schedule. ${ }^{119}$ Typical kinds of numerical limitations that a member might inscribe in its schedule of commitments include the following:

113 Id. art. XX:2, at 1181.

114 Hoekman, supra note 77, at 105-07.

115 See id. at 102 (listing numbers of commitments scheduled for individual GATS members). In 1995, the International Trade Commission completed a detailed analysis of the specific commitments made by Canada, the EU, Japan, and Mexico in the areas of distribution, education, communication, health care, professional, transportation, and travel and tourism. The Commission concluded that, of a possible 440 entries that each country could have made in these service sectors, these four trading partners entered full commitments ranging from 104 to 214 , or $24 \%$ to $49 \%$. See General Agreement on Trade in Services: Examination of Major Trading Partners' Schedules of Commitments 10-4, USITC Pub. 2940, Inv. 332-358 (Dec. 1995) [hereinafter USITC Examination of GATS]. The Commission undertook a parallel study in 1996 for South America. See General Agreement on Trade in Services: Examination of South American Trading Partners' Schedules of Commitments, USITC Pub. 3007, Inv. No. 332-367 (Dec. 1996).

116 See Hoekman, supra note 77, at 105 (discussing "the magnitude of commitments where no restrictions apply to both market access and national treatment for a given sector-mode of supply").

117 Id.

118 GATS, supra note 69, art. XVI:1, at 1179.

119 Id. art. XVI:2(a)-(f), at 1179-80. 
(1) limitations in the form of quotas or the requirement of an economic needs test on the number of service suppliers or operations; $\mathbf{1 2 0}^{120}$

(2) limitations in the form of quotas on the total value of service transactions or assets; 121

(3) measures that restrict or require specific types of a legal entity or joint venture through which a service supplier may supply a service; 122

(4) limitations on the total number of natural persons that may be employed in a particular service sector; ${ }^{123}$ and

(5) limitations on the participation of foreign capital in terms of a maximum percentage limit on foreign shareholding or the total value of individual or aggregate foreign investment. ${ }^{124}$

\subsubsection{Progressive Liberalization}

Appreciating that an agreement on the complete liberalization of trade in services would not happen overnight, Part IV of GATS schedules future negotiations for further liberalization of trade in services. It also lays down rules for negotiating schedules and for the subsequent modifications of those schedules. GATS Article XIX schedules successive rounds of negotiations beginning no later than 2000 and periodically thereafter. They are aimed at the progressive liberalization of trade in services. For each round, negotiating guidelines and procedures are to be established, taking into account the autonomous trade liberalization efforts undertaken by members since 1995 and the special situation of least-developed countries. ${ }^{125}$ GATS Article XIX contemplates that the process of progressive liberalization may take place through bilateral, plurilateral, or multilateral negotiations in each round, provided they

120 Id. art. XVI:2(a), (c), at 1179. Examples include a license for a new restaurant based on an economic needs test, annually established quotas for foreign medical practitioners, nationality requirements for service suppliers (equivalent to a zero quota), and restrictions on the amount of broadcasting time available for foreign films.

121 Id. art. XVI:2(b), at 1179. For example, foreign bank subsidiaries' assets might be capped at a fixed percentage of total domestic assets of all banks.

122 Id. art. XVI:2(e), at 1180. Examples include a requirement that foreign companies establish subsidiaries, or that in a particular sector commercial presence take the form of a partnership.

123 Id. art. XVI:2(d), at 1180.

124 Id. art. XVI:2(f), at 1180.

125 See id. art. XIX:3, at 1181 (describing negotiating schedules). 
are aimed at raising the overall level of specific commitments. ${ }^{126}$ Improved commitments on trade liberalization of most service sectors have been rolled over to the so-called Doha Development Agenda or Round. ${ }^{127}$

\subsubsection{Movement of Natural Persons}

Under the Annex on Movement of Natural Persons Supplying Services Under the Agreement ("Annex"), members agree to provide temporary entry for management and specialized personnel during the ordinary course of providing services. "Movement of natural persons" refers to the temporary admission of foreign nationals into the territory of another WTO Member as part of the business of supplying services abroad.128 The GATS does not apply to measures affecting natural persons seeking access to a member's employment market. It also does not apply to measures regarding citizenship, residence, or employment on a permanent basis. ${ }^{29}$

The Annex does not prevent a member from applying measures to regulate the entry of natural persons. Such measures may include measures to ensure the orderly movement of persons across borders, provided that the measures are not applied in a manner that nullifies or impairs the benefits accruing to any member under the terms of a specific commitment. However, the sole fact that a visa is required for natural persons of certain members and not others is not to be regarded as nullifying or impairing benefits under a specific commitment. ${ }^{130}$

As noted by India in a submission to the Working Group on the Relationship Between Trade and Investment, there has been a disconnect in the discussion about free movement of capital and any discussion about the free movement of labor. ${ }^{131}$ As India points out:

126 See id. art. XIX:4, at 1181 (discussing the different modes but common goal of progressive liberalization).

127 See infra notes 310-30 and accompanying text.

${ }^{128}$ GATS, supra note 69, Annex on Article II Exemptions, para. 1, at 1187-88.

129 Id. para. 2, at 1188.

130 Id. para. 4 n.1, at 1188.

131 WTO Working Group on the Relationship Between Trade and Investment, Communication from India, WT/WGTI/W/39 (June 4, 1998). 
Both the mobility of capital and the mobility of labour are accepted as delivery modes for trade and investment in goods and services. If capital is mobile and flows across countries and regions, it is a natural corollary that labour must also have comparable mobility. A liberal integrated approach is necessary to the mobility of labour as part of the free global flows of capital, goods and services. ${ }^{132}$

India's observation and suggestion that the movement of labor be taken up in the work program of the Working Group on the Relationship Between Trade and Investment has been all but ignored by the other participants.

\subsubsection{Summary: The Results of the GATS Negotiations}

Most market access and national treatment commitments to date are essentially standstill agreements. That is, existing market access and national treatment limitations, if any, are maintained. ${ }^{133}$ However, members commit not to impose additional trade restrictions in the future. ${ }^{134}$ Consequently, while the GATS lays a foundation, broad trade liberalization in services did not take place in the Uruguay Round. With the exception of the financial services and telecommunication services negotiations where members sought genuine liberalization of those two service sectors (discussed next), the most noteworthy achievement of the first round of services trade negotiations was to provide an unprecedented amount of information on barriers to services trade maintained by WTO members. Thus, through the commitments that identify measures that are barriers to services trade, the Uruguay Round negotiators accomplished the twin goals of establishing benchmarks for future services trade negotiations and making barriers to services trade more transparent where market access commitments were made. Because of the GATS positive list approach, however, benchmarks and transparency are non-existent if no market access commitment has been made for a service sector or subsector.

132 Id. para. 3.

133 USITC Examination of GATS, supra note 115, at 1-4.

134 Id. 


\subsubsection{Trade in Financial Services}

\subsubsection{Introduction}

Although the extent of market openings overall, including openings for FDI, were extremely modest in the Uruguay Round GATS negotiations, genuine market openings were achieved in the financial services and basic telecommunications sectors in postRound negotiations. Let us turn first to the financial services negotiations.

Realizing that a final agreement on financial services was out of reach by the December 1993 deadline for the Uruguay Round, participants agreed to continue negotiations on financial services through June 1995 to see if adequate market access commitments in the areas of banking, securities, and insurance could be secured. ${ }^{135}$ Frustrated with the reluctance of participants to make broad financial services offers during the Uruguay Round, the United States reacted by making conditional MFN offers as a negotiating tactic for prying more liberal offers from foot-draggers. ${ }^{136}$ Countries whose offers were deemed adequate received reciprocal offers from the United States. Unconditional MFN treatment was withheld, however, from countries that the United States considered to be "free riders." 137 This two-tiered approach rankled many participants as a dangerous departure from the near-sacrosanct unconditional MFN principle enshrined in GATT Article I. 138

The United States announced on June 28, 1995 that it would maintain its exemption from the MFN obligation relating to trade in financial services because it regarded the offers made by the other participants as insufficient. ${ }^{139}$ In response, the EU arranged for improved offers in an effort to induce other participants not to

135 Kenneth Freiberg, Introductory Note, World Trade Organization: Second Protocol to the General Agreement on Trade in Services (GATS) and Related Decisions, 35 I.L.M. 199, 200-01 (1996) [hereinafter Second Protocol to the GATS] (discussing the extensions to the financial services negotiations).

136 See id. at 201-02 (discussing U.S. tactics to deal with insufficient market access commitments by other nations).

137 Id.

138 See U.S. INT'L TRAdE COMm'N, THE YEAR IN TRADE 1994: Operation OF THE Trade AGReEMENTS Program 14, USITC Pub. 2894 (1995) [hereinafter THE YEAR IN TRADE 1994].

139 See Second Protocol to the GATS, supra note 135, at 202 (discussing the accommodations the United States made for countries whose offers were deemed insufficient). 
withdraw their financial services commitments. ${ }^{140}$ By July 1995, approximately thirty WTO members (counting the EU as one) reached an interim agreement on financial service commitments. They adopted a Second Protocol to the GATS, containing schedules of commitments that expired on December 12, 1997.141 That date coincided with the new date for the completion of the financial services follow-up negotiations that were launched in 1997.

In order to facilitate the post-Round financial services negotiations, the WTO members agreed at the end of the Uruguay Round to the Understanding on Commitments on Financial Services ("Understanding"). ${ }^{142}$ The Understanding was intended to harmonize the structure of the market access commitments agreed to by the members during the post-Round financial services negotiations.

First, the Understanding contains a standstill restriction that provides that members will only inscribe conditions, limitations, and qualifications to their specific commitments to the extent of $e x$ isting, non-conforming measures. ${ }^{143}$ (Under Part III of the GATS, in contrast, it is also possible for a member to inscribe future nonconforming measures in a member's schedule of commitments.)

Second, regarding market access commitments, members agree to the following eight rules: 144

(1) Members shall list in their schedules of financial service commitments existing monopoly rights and shall endeavor to eliminate them or reduce their scope.

(2) Notwithstanding GATS Article XIII on government procurement, members agree to accord MFN and national treatment to non-resident financial service suppliers in the purchase or acquisition of financial services by public entities.

(3) Members shall permit the cross-border delivery and purchase of insurance services relating to (a) maritime shipping, commercial aviation, and space launching; (b) reinsurance; and (c) financial information and data processing.

140 See THE YEAR IN TRADE 1994, supra note 138, at 31 n.83.

141 See Second Protocol to the GATS, supra note 135. For background on the financial services negotiations through 1997, see WTO, OPENING MARKETS IN FINANCIAL SERVICES AND THE ROLE OF THE GATS (Special Studies 1997).

142 GATS, supra note 69, Understanding on Commitments in Financial Services, at 1260 .

143 See id. at 1260 (discussing limitations of standstill provisions).

144 See id. at 1260-63 (outlining market access commitment rules). 
(4) Members shall grant non-resident financial service suppliers the right to establish a commercial presence within their territory, including through the acquisition of existing enterprises, subject to terms, conditions, and procedures for authorization of the establishment of a commercial presence that are otherwise consistent with the GATS.

(5) Members shall permit financial service suppliers of any other member established in the former's territory to offer any new financial service.

(6) Members shall not take measures that prevent transfers of information or the processing of information that are necessary for the conduct of ordinary business of a financial service supplier, subject to the right to protect personal data and privacy and the confidentiality of individual records and accounts.

(7) Members shall permit the temporary entry of personnel of a financial service supplier that has established a commercial presence in the territory of a member, including senior managerial personnel possessing proprietary information essential to the service supplier, specialists in the operation of the supplier, and, subject to the availability of qualified personnel within the member's territory, computer and telecommunications specialists, actuarial specialists, and legal specialists.

(8) Members commit to remove or limit any significant adverse effects on other members' financial service suppliers of (a) nondiscriminatory measures that prevent other members' financial service suppliers from offering all of the financial services permitted by the member; (b) non-discriminatory measures that limit the expansion of financial service activities into a member's entire territory; (c) measures that apply to both banking and securities services when the financial service supplier concentrates its activities in securities services; and (d) other measures that adversely affect the ability of financial service suppliers to operate, compete, or enter a member's market. Members need not, however, discriminate against their own financial service suppliers in honoring this commitment.

Third, regarding national treatment, members agree to provide financial service suppliers of other members access to payment and clearing systems operated by public entities, and to official funding and refinancing facilities available in the ordinary course of busi- 
ness, other than the facilities of a member's lender of last resort. ${ }^{145}$ When membership or participation in any self-regulatory body, securities or futures exchange, or any other organization, is required by a member as a condition of supplying a particular financial service on an equal footing with resident financial service suppliers, members must ensure that such entities accord national treatment to non-resident financial service suppliers. ${ }^{146}$

\subsubsection{The 1995 Interim Agreement on Financial Services}

With the Understanding on Commitments on Financial Services in place, the Uruguay Round participants had laid the groundwork for multilateral negotiations leading to a rules-based agreement on financial services. However, despite the best efforts of the Uruguay Round participants to chart a course toward deeper and broader offers on market access for financial services that would culminate in a comprehensive, multilateral agreement, those efforts failed to produce improved commitments from certain key players, most notably the United States. The United States concluded that market access commitments by some Asian countries, particularly India, Korea, and Malaysia, were not adequate to warrant U.S. support of a comprehensive agreement. ${ }^{147}$ Accordingly, the United States signed the Second Protocol and submitted its schedule of commitments that included an MFN exemption restricting access to its financial services sector to other members' financial services suppliers on the basis of reciprocal treatment of U.S. suppliers by those members. ${ }^{148}$

Undaunted, the other participants, behind the leadership of the $\mathrm{EU}$, reduced their commitments to a Second Protocol to the

145 Id. para. C.1, at 1263.

146 Id. para. C.2, at 1263.

147 See BHALA, supra note 45 , at 747.

148 See id. at 748; WTO, United States: Specific Schedule of Commitments, GATS/SC/90/Supp. 1, and List of Article II (MFN) Exemptions, GATS/EL/90/Supp. 1 (1995), reprinted in U.S. Schedule of Commitments, supra note 103, app. B-1; James Bedore, Financial Services: An Overview of the World Trade Organization's Negotiations, INDUSTRY, TRADE, \& TECH. REV. 1, USITC Pub. 2942 (Dec. 1995); Financial Services Committee Approves Accord Without U.S., 12 Int'1 Trade Rep. (BNA) 1311 (Aug. 2, 1995); Japan, South Korea Sign On to Financial Services Accord, 12 Int'l Trade Rep. (BNA) 1266 (July 26, 1995); ASEAN Members Agree to Maintain Offers in WTO Financial Services Negotiations, 12 Int'1 Trade Rep. (BNA) 1175 (July 12, 1995). 
GATS, 149 the implementing document of the interim financial service agreement ("Interim Agreement") that contains their schedules of commitments on financial services. The Interim Agreement of 1995 contains commitments from thirty-one countries covering $90 \%$ of world trade in financial services, including some access to members' banking, insurance, and securities markets. ${ }^{150}$ The commitments extend to all WTO members on an MFN basis.

\subsubsection{The 1997 Agreement on Financial Services}

Negotiations on a comprehensive financial services agreement resumed on April 7, 1997. Participants set December 12, 1997 as the deadline for reaching an agreement. ${ }^{151}$ Negotiators started with a clean slate, so that all members that had made commitments under the interim agreement started from zero. The negotiations were successfully completed on December 12, 1997, with the agreement to enter into force by March 1, 1999 at the latest. ${ }^{152} \mathrm{~A}$ total of fifty-six offers (representing seventy countries, counting the EU member states as one) were submitted and annexed to the Fifth Protocol to the GATS, bringing to 102 the number of WTO mem-

149 Second Protocol to the GATS, supra note 135. The Second Protocol entered into force on September 1, 1996, and expired on December 12, 1997. Id. WTO members involved in negotiating the Second Protocol include Australia, Brazil, Canada, Chile, the Czech Republic, the Dominican Republic, Egypt, the EC, Hong Kong, Hungary, India, Indonesia, Japan, Korea, Kuwait, Malaysia, Mexico, Morocco, Norway, Pakistan, the Philippines, Poland, Singapore, the Slovak Republic, South Africa, Switzerland, Thailand, Turkey, and Venezuela. BHALA \& KENNEDY, supra note 3 , at 1280 n.131.

150 See BHALA, supra note 45, at 748. A list of the WTO members making commitments under the 1995 Interim Agreement is available at http://www .wto.org/english/tratop_e/serv_e/finance_e/finance_commitments_e.htm. For example, the Philippines opened its insurance market to foreign firms for the first time in fifty years. Thailand committed to issue seven extra banking licenses by 1997. Brazil opened participation in the privatization of its banks to foreign firms. BHALA \& KENNEDY, supra note 3 , at 1280.

151 WTO Council for Trade in Services, Decision on Financial Services Negotiations, S/L/39 (1997). For background on the 1995 Interim Agreement negotiations and the 1997 WTO financial services negotiations, see WTO, Background Note, The Results of the Financial Services Negotiations Under the General Agreement on Trade in Services (GATS), available at http://www.wto.org/english/tratop_e /serv_e/finance_e/finance_fiback_e.htm.

152 WTO, Background Note, supra note 151. As a result of the negotiations, the United States, Columbia, and Thailand decided to withdraw their broad MFN exemptions based on reciprocity. Only a small number of countries submitted limited MFN exemptions or maintained existing broad MFN exemptions. Id. 
bers that made financial services commitments under the GATS. 153 As measured in revenue, the agreement covers more than $95 \%$ of trade in banking, insurance, securities, and financial information. ${ }^{154}$

In the insurance sector, for example, fifty-two countries representing over $90 \%$ of world insurance premiums have guaranteed market access through a commercial presence for all insurance subsectors (i.e., life, non-life, reinsurance, brokerage, and auxiliary services). ${ }^{155}$ Forty-five countries permit $100 \%$ ownership of insurance subsidiaries or entry through branches, including the Quad members and Mexico; seven countries allow 100\% ownership of subsidiaries, but no entry through branches (i.e., Brazil, Chile, Indonesia, Jamaica, Nicaragua, South Africa, and Venezuela); and nine countries allow majority control of insurance subsidiaries (i.e., Egypt, Ghana, Kenya, Pakistan, the Philippines, Romania, Singapore, Slovenia, and Thailand). ${ }^{156}$

The participants in the 1997 financial services negotiations also made commitments in connection with the cross-border delivery of insurance services. ${ }^{157}$ For example, in the specialty category of marine, aviation, and transport ("MAT") insurance, twenty-seven countries now permit cross-border MAT insurance, including Canada, the EU and Mexico. ${ }^{158}$ Thirty-five countries have made commitments in the reinsurance and brokerage subsectors of cross-

153 For a summary of the improvements in the new financial services commitments, see Press Release, WTO, Successful Conclusion of the WTO's Financial Services Negotiations (Dec. 15, 1997), available at http://www.wto.org/english /news_e/pres97_e/pr86_e.htm; Press Release, Office of the Press Secretary, Statement by Secretary Rubin and Ambassador Barshefsky Regarding the Successful Conclusion of WTO Financial Services Negotiations (Dec. 13, 1997), available at http://www.ustr.gov/releases/1997/12/finserv.pdf; Press Release, Office of the U.S. Trade Representative, World Trade Organization (WTO) Financial Services Negotiations (Dec. 13, 1997), available at http://www.ustr.gov/releases /1997/12/finserv1.pdf.

154 See Press Release, Statement by Secretary Rubin and Ambassador Barshefsky, supra note 153 (listing the commitments made on a country-by-country basis); WTO, Non-Attributable Summary of the Main Improvements in the New Financial Services Commitments (Feb. 26, 1997) (listing the commitments made on a country-by-country basis), available at http://www.wto.org/english/news_e /news98_e/finsum.htm.

155 See Press Release, Office of the U.S. Trade Representative, WTO Financial Services Negotiations, supra note 153, at 1.

156 Id.

157 Id. at 3.

158 Id. 
border insurance activities.159 For example, Japan has authorized the cross-border delivery of reinsurance, but not brokerage services. 160

In banking, sixty countries guarantee a right of establishment for banks. 161 Thirty-five countries, including the Quad members, permit $100 \%$ ownership of subsidiaries or branches. Sixty-four countries have grandfathered acquired rights of foreign banks. ${ }^{162}$

In the securities sector, forty-five countries, including the Quad members, guarantee a right of establishment of foreign securities firms. ${ }^{163}$ Thirty-seven of them permit $100 \%$ ownership of subsidiaries or branches. ${ }^{164}$ Fifty-nine countries have grandfathered the rights of foreign securities firms. ${ }^{165}$ Fifty countries permit foreign firms to provide and transfer financial data and information. ${ }^{166}$

In sum, in marked contrast to the flaccid results of the Uruguay Round negotiations on services trade in general, the 1997 agreement on financial services achieved significant market liberalization for FDI in the financial services sector. The 1997 agreement demonstrates what is possible in sectoral, FDI negotiations. Similar results were achieved in the telecommunication services sector, discussed next.

\subsubsection{Telecommunications Trade}

\subsubsection{Introduction}

Telecommunication products and services are an increasingly valuable and growing component of an advanced economy's manufacturing base. Near the start of the post-Round negotiations on basic telecommunications in 1995, global telecommunication services revenue stood at $\$ 601.9$ billion, or $2.1 \%$ of global gross domestic product $\left(" G D P^{\prime \prime}\right) .{ }^{167}$ The world telecommunications

159 Id.

160 Id.

161 Id. at 4.

162 Id. at 5.

163 Id. at 4.

164 Id.

165 Id. at 5.

166 Id. at 4.

167 See WTO, Data on Telecommunications Markets Covered by the WTO Negotiations on Basic Telecommunications (Feb. 17, 1997) ("Revenue from international service was estimated at nearly $\$ 63$ billion in 1995 ; accounting for $10 \%$ of 
market is clearly an economically valuable one. It also is a fastgrowing one, with average annual revenue growth rates of $4.2 \%$ from 1990 to 1995 in industrialized countries, and 9.7\% in developing countries in that same period. ${ }^{168}$ In 1995, the EU, Japan, and the United States together accounted for nearly three-quarters of total revenue in world telecommunications. ${ }^{169}$

It is against this backdrop that the WTO members negotiated several commitments on telecommunications services trade, both during the Uruguay Round and after. At the conclusion of the Uruguay Round in December 1993, approximately one-half of the participants scheduled specific commitments on value-added telecommunication services. ${ }^{170}$ Negotiations on basic telecommunication services were extended through 1996 and concluded in 1997 (discussed below). The Uruguay Round participants also reached agreement on access to members' telecommunication networks, memorialized in the GATS Annex on Telecommunications (discussed next).

\subsubsection{The GATS Annex on Telecommunications}

The telecommunications sector serves a dual role as both a distinct sector of economic activity and as the means of delivery for other economic activities. Recognizing this duality, the GATS Annex on Telecommunications was negotiated to ensure that in its

total revenue."), available at http://www.wto.org/english/news_e/pres97_e /data3.htm.

Telecommunication services are commonly bifurcated into basic and valueadded services. Value-added services are sometimes referred to in the United States as "enhanced" services. Basic telecommunication services include voice telephone, telex, and telegraph. Value-added services are computer-based and include electronic and voice mail, online and database information retrieval, and data and transaction processing. See Michael Nunes, U.S. Telecommunication Services: Industry and Trade Outlook, INDUSTRY TRADE \& TECH. REV. 1 nn. 2 \& 3 (July 2002); WTO, Coverage of Basic Telecommunications and Value-Added Services (defining and giving examples of basic and value-added telecommunications services), available at http://www.wto.org/english/tratop_e/serv_e/telecom_e /telecom_coverage_e.htm.

168 See WTO, Data on Telecommunications Markets Covered by the WTO Negotiations on Basic Telecommunications (Feb. 17, 1997), available at http://www.wto.org/english/news_e/pres97_e/data3.htm.

169 Id.

170 BHALA \& KENNEDY, supra note 3, at 1290. 
role as the means of delivery, access to telecommunication networks does not turn into a non-tariff barrier to trade. ${ }^{171}$

The scope of the Annex is broad, but not universal. It applies to all measures that affect access to and the use of public telecommunication transport networks and services, but does not apply to measures affecting cable or broadcast distribution of radio or television programming. ${ }^{172}$ Every WTO member must ensure that the obligations of the Annex are applied to their own suppliers of public telecommunication transport networks and services by whatever means necessary. 173

Unless a member has scheduled a specific commitment that requires access or use, nothing in the Annex requires a member to authorize a service supplier of any other member to establish, construct, acquire, or otherwise supply telecommunication transport networks or services. ${ }^{174}$ Likewise, and undoubtedly to the relief of developing countries, the Annex does not require a member to acquire, lease, or build a telecommunications network or supply telecommunication services that are not offered to the public generally. 175

The heart of the Annex is paragraph 5, whose heading could easily serve as the subtitle of the Annex: Access to and Use of Public Telecommunications Transport Networks and Services. Paragraph 5(a) provides, in pertinent part, "[E]ach Member shall ensure that any service supplier of any other Member is accorded access to and use of public telecommunications transport networks and services on reasonable and non-discriminatory terms and conditions, for the supply of a service included in its Schedule."

171 GATS, supra note 69 , Annex on Telecommunications, at 1192 . For an analysis of the Annex on Telecommunications, see Taunya L. McLarty, Liberalized Telecommunications Trade in the WTO: Implications for Universal Service Policy, 51 FED. COMM. L.J. 1, 38-42 (1998).

172 GATS, supra note 69, Annex on Telecommunications, para. 2(a)-(b), at 1193. Public telecommunications transport service means a service that a member requires to be offered to the public generally (thus, they may be privately owned), and includes telegraph, telephone, telex, and data transmission. Id. para. 3(b). Public telecommunication transport network means the infrastructure which permits telecommunications between defined network termination points. Id. para. 3(c).

173 Id. para. 2(a) n.1.

174 Id. para. 2(c)(i).

175 Id. para. 2(c)(ii). 
A footnote clarifies that the term "non-discriminatory" refers to MFN and national treatment, as defined in the GATS.176 It adds that sector-specific usage of the term means "terms and conditions no less favourable than those accorded to any other user of like public telecommunications transport networks or service under like conditions." This language strongly suggests that no derogations from the MFN or national treatment obligations may be listed in a member's schedule of commitments regarding access to or use of public telecommunication networks or services.

The specific access and use rights accorded foreign service suppliers include: (1) the right to purchase or lease and attach terminal or other equipment that is necessary to supply services; (2) the right to interconnect private leased or owned circuits with public networks or services; (3) the right to use operating protocols of the supplier's choice in the supply of any service; and (4) the right to use networks and services for the movement of information within and across borders, subject to reasonable measures necessary to ensure security and confidentiality (e.g., encryption requirements). ${ }^{177}$

A member may impose three general types of measures on access and use. First, a member may impose measures necessary to ensure that public service suppliers are able to make their networks or services available to the public generally. ${ }^{178}$ Second, a member may impose measures necessary to protect the technical integrity of networks or services. ${ }^{179}$ Third, a member may impose measures necessary to ensure that service suppliers are providing only services for which the member has scheduled a commitment. 180 Provided that the conditions fall within one of the three types of permissible measures just described, a member may impose specific conditions on access and use. These conditions include: (1) restrictions on resale or shared use; (2) requirements to use specified technical interfaces and protocols for inter-connection with such networks and services; (3) approval of terminal or other equipment that interfaces with the network; (4) restrictions on inter-connection of private leased or owned circuits with such net-

176 Id. para. 5(a) n.2, at 1194.

177 Id. para. 5(b)-(d). Cf. GATS Art. III bis, at 1170.

178 GATS, supra note 69, Annex on Telecommunications, para. 5(e)(i), at 1194.

179 Id. para. 5(e)(ii).

180 Id. para. 5(e)(iii). 
works or services; and (5) requirements on registration and licensing. ${ }^{181}$

Developing countries are given a special dispensation that allows them to protect (or "strengthen" in the words of the Annex) their domestic telecommunications infrastructure and service capacity through reasonable conditions on access and use, notwithstanding the limitations imposed on members by paragraph 5.182 Any such conditions must be specified in the developing country member's schedule (which no member has done). The Annex also encourages technical cooperation between developed and developing members. 183

Finally, recognizing the importance of international standards for global compatibility and inter-operability of telecommunication networks and services, members agree in paragraph 7 to promote such standards through appropriate international organizations, including the International Telecommunication Union and the International Organization for Standardization. ${ }^{184}$ Members also agree to engage relevant Non-Governmental Organizations by making arrangements with them for consultation on matters arising from the implementation of the Annex.185

In summary, what the Annex on Telecommunications represents is a national treatment commitment that sets the stage for equal treatment of foreign telecommunication service providers vis-à-vis their domestic competitors if and when market access is offered to the former. Such market access was secured at least in part during the Uruguay Round in the case of value-added telecommunications services.

\subsubsection{Commitments on Value-Added Telecommunication Services}

Value-added telecommunication service suppliers create global networks by leasing lines from basic telecommunication carriers. Consumers can access value-added services, such as e-mail or computer databases, by connecting to a value-added telecommunication network through a personal computer. Consumers can use

\footnotetext{
181 Id. para. $5(\mathrm{f})$.

182 Id. para. $5(\mathrm{~g})$.

183 Id. para. 6.

184 Id. para. 7(a).

185 Id. para. 7(b).
} 
a local telephone number provided by the supplier, a long-distance number, an Integrated Services Digital Network ("ISDN") connection through a local telephone network, or a local telephone company to connect to a network. ${ }^{186}$ The modes of delivery for valueadded telecommunication services are either cross-border or through a foreign commercial presence. ${ }^{187}$ Physical delivery occurs through telecommunication and computer networks that link communication centers throughout the world. 188 As noted above, the Annex on Telecommunications ensures suppliers reasonable and nondiscriminatory access to and use of public telecommunication network carriers and services when such services or facilities are required to supply a service included in a member's schedule of commitments.

The Uruguay Round negotiations on specific commitments on value-added telecommunication services were a modest success. Fifty-eight countries, including all of the Quad members, scheduled commitments on value-added telecom services. As is true with the vast majority of specific GATS commitments negotiated during the Uruguay Round, however, the value-added service commitments are standstill commitments that maintain the status quo rather than liberalize trade. ${ }^{189}$ However, because the global market for value-added telecom services was comparatively open at the start of the negotiations, the standstill commitments made in the Uruguay Round prevent rollbacks on existing market access. 190

With a few exceptions, U.S. providers of value-added telecommunication services operate freely in Canada, the EU, Japan, and Mexico. ${ }^{191}$ This open business environment for value-added telecommunication services is largely the by-product of bilateral and regional agreements that predate the GATS. ${ }^{192}$ Nevertheless,

186 See USITC Examination of GATS, supra note 115, at 5-2 (describing the nature of international trade in value-added telecommunication services).

187 Id.

188 Id.

189 Id. at 5-3.

190 See Richard Brown, Basic Telecommunications Service Negotiations in the World Trade Organization: Impetus, Offers, and Prospects, INDUSTRY, TRADE \& TECH. REV. 1, 5-6, USITC Pub. 3017 (Jan. 1997) (describing background and achievements of the Uruguay Round basic telecommunication services negotiations).

191 See USITC Examination of GATS, supra note 115, at 5-4, tbl.5-1 (highlighting commitments made by U.S. major trading partners).

192 For example, the United States and Japan concluded an international value-added network services ("IVANS") agreement in 1991 that provided market access to Japanese business markets for U.S. providers of value-added telecom- 
the GATS buttresses this already favorable climate through the standstill commitments scheduled by the Quad members.

First, with regard to the cross-border delivery of value-added telecommunication services, market access is virtually unrestricted in Canada, the EU, Japan, and the United States. ${ }^{193}$ While no national treatment limitations exist in Mexico, some modest market access restrictions require that a permit be obtained to provide many types of value-added services. ${ }^{194}$ None of the Quad members listed any MFN exemptions that apply directly to value-added telecommunication services. ${ }^{195}$

Second, with regard to the delivery of value-added telecom services through a commercial presence, foreign service suppliers face far more restrictions within all Quad members. Thus, for example, while Canada and Japan do not have any limitations that are specifically targeted at the value-added telecom service sector, cross-industry ("horizontal") restrictions on market access include capping equity ownership, voting rights, and representation on boards of directors. 196 Typical cross-industry limitations on national treatment include requirements that newly established businesses be controlled by residents of the host country. ${ }^{197}$

Value-added telecommunication service providers in the United States have expressed overall satisfaction with the GATS commitments made by Canada, the EU, Japan, and Mexico. ${ }^{198}$ Their main criticism is the GATS' scheduling methodology. ${ }^{199}$ The U.S. industry complains that the GATS's positive list approach does not automatically accord market access or national treatment to new services that grow out of technological advances. ${ }^{200}$ Because restrictions on emerging services are unbound, trading part-

munication services. See id. at 5-6. NAFTA also provides U.S. value-added service suppliers with liberalized access to the Canadian and Mexican markets. See id. at 5-5.

193 Id. app. L.

194 See Marie C. Wold, Liberalization of the Mexican Telecommunication Sector, INDUSTRY, TRADE, \& TECH. REv. 1, USITC Pub. 3039 (Apr. 1997) (discussing the effects of Mexico's liberation of its long-distance telecommunications sector on U.S. investment, trade, and employment in that industry).

195 USITC Examination of GATS, supra note 115, at 5-3.

196 Id. at 5-3.

197 Id.

198 Id. at 5-6.

199 Id.

200 Id. 
ners may impose on such services whatever national treatment limitations or market access restrictions they choose without paying compensation to adversely affected WTO members. NAFTA's negative list approach in the services sector is, for that reason, a preferable methodological approach, because all emerging services are automatically entitled to market access and national treatment. 201

\subsubsection{The 1997 Agreement on Basic Telecommunication Services}

While several countries offered commitments on value-added telecommunications during the Uruguay Round, the negotiations on basic telecommunications were a different story. ${ }^{202}$ The reason for this difference is explained by the wide variations in openness among countries in their basic telecommunications markets. As noted by Bhala and Kennedy in this regard:

For example, in contrast to the open and competitive U.S. telecommunications market that followed the 1984 breakup of AT\&T, the basic telecommunications market in Europe is dominated by public and private monopolies or single service providers. Because of this gulf in perspectives, offers on basic telecommunications were slow to develop. ${ }^{203}$

Despite these hurdles, rather than end negotiations on this branch of telecommunication services trade, the participants agreed instead to extend negotiations on basic telecommunications for two years. ${ }^{204}$ After a further extension of negotiations, an

201 See USITC Examination of GATS, supra note 115, at 5-6.

202 See Laura B. Sherman, Introductory Note, World Trade Organization: Agreement on Telecommunications Services (Fourth Protocol to General Agreement on Trade in Services), 36 I.L.M. 354, 355 (1997) (noting that "[b]asic telecommunications was one of the four services sectors left unresolved by the Uruguay Round").

203 BHALA \& KENNEDY, supra note 3, at 1290.

204 WTO Ministerial Conference, Decision on Negotiations on Basic Telecommunications, para. 5, 33 I.L.M. 144, 145 (1994). 
Agreement on Basic Telecommunications was finally concluded in early 1997.205

On February 15, 1997, sixty-nine developed and developing countries from fifty-five WTO members (fifty-four governments plus the fifteen EU member states) successfully concluded an agreement on basic telecommunication services that entered into force on January 1, 1998.206 No single document memorializes the participants' "agreement" per se.207 Rather, the legal document that provides authoritative and complete information on the commitments made by each participant is the National Schedule of Specific Commitments annexed to the Fourth Protocol of the General Agreement on Trade in Services. ${ }^{208}$ The basic telecommunication services covered by the agreement are defined broadly as any telecommunication transport network or service. ${ }^{209}$

205 See Sherman, supra note 202, at 356-58 (discussing Basic Telecommunications negotiations).

206 Id. at 357 n.23; WTO Negotiating Group on Basic Telecommunications, Report of the Group on Basic Telecommunications, para. 6, S/GBT/4 (Feb. 15, 1997), 33 I.L.M. 369, 370 (1997).

207 See Sherman, supra note 202, at 357-58 (describing the various documents that form the package that is the agreement on basic telecommunications).

$208 \mathrm{See}$ WTO, Fourth Protocol to the General Agreement on Trade in Services, S/L/20 (Apr. 30, 1996), 36 I.L.M. 366 (1997) (agreeing to a Schedule of Specific Commitments).

209 See Sherman, supra note 202, at 359 (noting that all types of basic services are included); Press Release, WTO, The WTO Negotiations on Basic Telecommunications: Informal Summary of Commitments and M.F.N. Exemptions (Mar. 6, 1997) [hereinafter WTO Negotiations on Basic Telecommunications Press Release] (noting that "[u]nder a very broad and essentially open-ended definition employed for the negotiations, basic telecommunications were considered any telecommunications transport networks or services"), available at http://www .wto.org/english/news_e/pres97_e/bt summ3.htm. The WTO has identified the following services as being within the scope of the basic telecommunications services negotiations: voice telephone services, packet-switched data transmission services, circuit-switched data transmission services, telex services, telegraph services, facsimile services, private leased circuit services, mobile telephone services, mobile data services, paging, personal communications services, satellite-based mobile services, fixed satellite services, and teleconferencing. WTO Negotiations on Basic Telecommunications Press Release, supra. Circuit-switching is the technical description of older technology for the switching process that dedicates to two or more users the exclusive use of the circuit until the connection is terminated. Packet-switching is newer technology that is used almost exclusively for data exchange. Unlike circuit-switched data, packet-switched data are transmitted in multiple "packets" through available circuits and reassembled at the termination point. See generally From Circuits to Packets, ECONOMIST, Sept. 13, 1997, at 25-27 (discussing telecommunications). 
The market access openings achieved in the negotiations are impressive. The agreement covers $95 \%$ of world revenue in telecommunication services (before the agreement, only $17 \%$ of the top twenty telecommunication markets were open to foreign service providers). ${ }^{210}$ With the agreement, close to $100 \%$ of those markets are now open. ${ }^{211}$

The fifty-five national schedules of specific commitments have three elements: market access, investment, and pro-competitive regulatory principles. A sample of the market access commitments shows that sixty-one countries, representing $99 \%$ of WTO members' total basic telecommunication services revenue, commit to the competitive supply (i.e., two or more suppliers are permitted) of international voice telephone services and other international services either immediately on January 1, 1998 or, in the case of twenty-four countries, on a phased-in timetable.212 Forty-one schedules list commitments on local service; thirty-eight list commitments on domestic long-distance service; and forty-two list commitments on international service. ${ }^{213}$ Market access commitments on other basic telecommunication services include fortynine schedules with commitments on data transmission service, forty-six on cellular/mobile telephone service, forty-one on leased circuit service, and thirty-six on fixed satellite service.214 Nine countries listed MFN exemptions (Argentina, Antigua and Bar-

210 See Press Release, Office of the U.S. Trade Representative, Statement of Ambassador Charlene Barshefsky, Basic Telecom Negotiations (Feb. 15, 1997) [hereinafter USTR Basic Telecom Negotiations Press Release] (summarizing the commitments for each of the fifty-five participants), available at WTO Negotiations on Basic Telecommunications Press Release, supra note 209 (including text summarizing the commitments for each of the fifty-five participants on a member-bymember basis).

211 See USTR Basic Telecom Negotiations Press Release, supra note 210, at 1; WTO Negotiations on Basic Telecommunications Press Release, supra note 209.

212 See USTR Basic Telecom Negotiations Press Release, supra note 210, at 1.

213 WTO Negotiations on Basic Telecommunications Press Release, supra note 207. The following countries deferred full market access to international telephone services: Spain, until December 1, 1998; Peru, until 1999; Argentina, Ireland, Portugal, Singapore, and Venezuela, until 2000; Bolivia and the Czech Republic, until 2001; Greece, Poland, Romania, and the Slovak Republic, until 2003; Hungary, Mauritius, until 2004; Bulgaria, Indonesia, until 2005; Grenada, Senegal, Thailand, and Turkey, until 2006; Brunei, until 2010; Antigua and Barbuda, until 2012; and Jamaica, until 2013. See USTR Basic Telecom Negotiations Press Release, supra note 210 , at 9 .

214 WTO Negotiations on Basic Telecommunications Press Release, supra note 209 , para. 4 . 
buda, Bangladesh, Brazil, India, Pakistan, Sri Lanka, Turkey, and the United States). ${ }^{215}$

On foreign direct investment, most schedules of commitments (fifty-six countries covering $97 \%$ of WTO members' total basic telecommunication services revenue) permit delivery through some form of a commercial presence. 216 Foreign service suppliers thus have the right to acquire, establish, or own all or part of a foreignbased telecommunications company. Focusing on the major trading partners of the United States (the EU, Japan, Canada, and Mexico), the EU, for example, in its schedule of commitments, agreed to full market access and national treatment with respect to the delivery of the following services through a commercial presence: voice telephone, packet-switched data transmission, circuitswitched data transmission, telex, telegraph, facsimile, leased circuit, and mobile and personal communication systems. ${ }^{217}$ With respect to these same services, however, Japan limits foreign capital participation in its two largest carriers, Nippon Telegraph and Telephone and Kokusai Denshin Denwa, to a maximum of $20 \% .218$ Canada likewise restricts the delivery through a commercial presence of basic telecommunication services by limiting foreign capital participation in most basic telecommunication service companies based in Canada to $20 \%$ direct ownership and $46.7 \%$ combined

215 Id.

216 See USTR Basic Telecom Negotiations Press Release, supra note 210, at 7.

217 Id. at 4; WTO Negotiations on Basic Telecommunications Press Release, supra note 209, para. 29 ("The EC offer commits to complete liberalization of basic telecom services (facilities-based and resale) across the EC for all market segments (local, long distance, and international). The offer also covers, for example, satellite networks and services and all mobile and personal communications services and systems."); WTO, European Communities and Their Member States, Schedule of Specific Commitments, GATS/SC/31/Suppl.3 (1997). Some EU member states have deferred the implementation of the commercial presence commitment until 2000 (Ireland and Portugal) and 2003 (Greece). See USTR Basic Telecom Negotiations Press Release, supra note 210, at 7.

218 WTO, Japan, Schedule of Specific Commitments, GATS/SC/46/Suppl.2 (1997); WTO Negotiations on Basic Telecommunications Press Release, supra note 209, para. 41.

In April 1996, agreed to remove long-standing foreign equity limits on Type I carriers and radio-based services, leaving only two companies, KDD and NTT, with foreign equity limits (at 20\%). Aside from these company-specific restrictions, open market access is committed in all market segments for basic telecommunications services (facilities-based and resale).

Id. 
direct and indirect ownership. ${ }^{219}$ Mexico also inscribed market access limitations with regard to delivery through a commercial presence for all telecommunications service suppliers. Direct foreign participation in such companies is capped at $49 \% .220$ An exception exists, however, for cellular services, where Mexico allows $100 \%$ foreign ownership. 221

\subsubsection{The Regulatory Framework for Basic Telecommunica- tions Services}

The basic telecommunications industry historically has been dominated by monopoly service suppliers. Against this historical backdrop, the WTO Negotiating Group on Basic Telecommunications recognized that in order for the market access commitments to be fully realized and for new market entrants to be able to compete effectively in this monopolistic business climate, it was essential that the participants reach agreement on a set of principles governing the regulatory framework for basic telecommunications services.222 To that end, the Negotiating Group developed a socalled Reference Paper on competition principles generally relating to anti-competitive behavior, interconnection, universal service, transparency in licensing, independence of regulators, and allocation of resources.223 More specifically, the Reference Paper addresses the following issues:

(1) Safeguards against certain anti-competitive practices by monopolies are to be put in place, such as cross-subsidization or

219 WTO, Canada, Schedule of Specific Commitments, GATS/SC/16/Suppl.3 (1997); WTO Negotiations on Basic Telecommunications Press Release, supra note 209, para. 20 ("Limits foreign equity in all facilities-based suppliers to $20 \%$ direct and $46.7 \%$ combined direct and indirect foreign ownership.").

220 WTO, México, Lista de compromisos específicos [Schedule of Specific Commitments], GATS/SC/56/Suppl.2 (1997); WTO Negotiations on Basic Telecommunications Press Release, supra note 209, para. 45 ("raising the foreign equity limitation to $49 \%$ for all telecommunications service suppliers").

221 See WTO Negotiations on Basic Telecommunications Press Release, supra note 209 , para. 45 ("For cellular telephony, allows more than $49 \%$ foreign investment subject to prior authorization."); Wold, supra note 194, at 6 ("Although Mexico generally limited foreign investment in telecommunications services providers to $49 \%$, Mexico's commitment to the WTO permits $100 \%$ ownership of firms providing cellular services.").

222 See Sherman, supra note 202, at 357 (explaining the results of the Negotiating Group on Basic Telecommunications).

223 See id.; Reference Paper, 36 I.L.M. 367 (1997). The source for the Reference Paper is the Telecommunications Act of 1996, 47 U.S.C. $\$ \S 251-61$ (2000). See USTR Basic Telecom Negotiations Press Release, supra note 210, at 5. 
using information obtained from competitors with anticompetitive results. 224

(2) Interconnection is to be cost-based and timely, on nondiscriminatory terms, rates, and quality. ${ }^{225}$

(3) Universal service requirements (i.e., requirements that mandate basic telecommunication service for every citizen at affordable prices) are to be transparent and non-discriminatory. ${ }^{226}$

(4) Licensing criteria must be transparent and publicly available. The reasons for the denial of a license are to be made available to the applicant upon request.227

(5) Regulators must be independent from suppliers of basic telecommunication services. 228

(6) Rules for the allocation of scarce resources, such as radio spectrum frequencies, are to be transparent and nondiscriminatory.229

Sixty-five of the sixty-nine participating governments, covering 93\% of WTO members' total basic telecommunication services revenue, inscribed commitments on regulatory principles in their national schedules. ${ }^{230}$ Of these, fifty-seven committed to the Reference Paper by inscribing it in whole or in part in their schedule of commitments, including the Quad members and Mexico.231 Bangladesh, Brazil, Mauritius, Morocco, Turkey, and Venezuela deferred the date of entry into force of the regulatory principles. Bolivia, India, Malaysia, Pakistan, and the Philippines adopted them in part.232

Of all the service sectors for which GATS commitments have been made, the scope of the commitments made on basic telecommunications services is the most ambitious to date. It opens the world's three largest telecommunication markets - the EU, Japan, and the United States - to international competition. As of mid-

\footnotetext{
224 Reference Paper, supra note 223, para. 1.2, at 367 .

225 Id. para. 2.2, at 368 .

226 Id. para. 3 , at 368 .

227 Id. para. 4 , at 369 .

228 ld. para. 5 , at 369 .

229 Id. para. 6.

230 See USTR Basic Telecom Negotiations Press Release, supra note 210, at 5,

231 Id. at 8; WTO Negotiations on Basic Telecommunications Press Release, supra note 209, para. 6 ("Fifty-seven committed to the Reference Paper in whole or with few modifications.").

232 Id.
} 8. 
2002, eighty-nine countries had made commitments on at least one telecommunication subsector. ${ }^{233}$ Additional market openings are being sought in the follow-on GATS negotiations that were initiated in 2000,234

\subsubsection{The TRIMs Agreement}

Working to bolster the FDI commitment made under the GATS and the 1997 Agreements on Financial Services or Basic Telecommunications is the Agreement on Trade-Related Investment Measures (the "TRIMs Agreement") concluded during the Uruguay Round. ${ }^{235}$ The TRIMs Agreement represents a very modest attempt to reinforce GATT rules respecting national treatment and the prohibition on import quotas, but falls short of being a comprehensive set of rules regulating international investment. ${ }^{236}$ The TRIMs Agreement builds on GATT Article III, which requires members to provide national treatment to imported products, and GATT Article XI, which prohibits members from imposing quantitative restrictions on the importation or exportation of goods. Although GATT Article III:4, 5, and 7 do apply to certain aspects of investment laws, the GATT panel dispute involving the Canadian Foreign Investment Review Act spotlighted the need for Article III

233 See Nunes, supra note 167 , at 8-9.

234 See, e.g., id. at 9 ("In general, the negotiating proposals seek to encourage full commitments on telecommunications services, eliminate restrictions on market access and national treatment."); WTO Council for Trade in Services, Special Session, Communication from Canada, Initial Negotiating Proposal on Telecommunication Services, Initial Negotiating Proposal on Telecommunications Services, para. 6, S/CSS/W/53 (Mar. 14, 2001) (urging "those Members that have not made commitments in the area of basic telecommunications and value-added telecommunications, or that have made limited commitments or commitments with long phase-in periods, to make commitments and to accelerate liberalization"); WTO Council for Trade in Services, Special Session, Communication from the European Communities and Their Member States, GATS 2000: Telecommunications, para. 12, S/CSS/W/35 (Dec. 22, 2000) (proposing that all WTO members "[c]ommit for Modes 1, 2 and 3 all sub-sectors and all modes without restrictions (i.e., schedules should read none for market access and national treatment), and include as additional commitments the whole reference paper on BT [Basic Telecommunications]").

235 See Agreement on Trade-Related Investment Measures, reprinted in URUGUAY ROUND TRADE AGREEMENTS, STATEMENT OF AdMINISTRATIVE ACTION 1, H.R. Doc. 316, 103d Cong., 1448 (1994) [hereinafter TRIMs Agreement].

236 For background on the TRIMs Agreement, see Mashayekhi, supra note 19, at 237-39 (noting the divergent positions of the United States and Japan, on the one hand, which sought broad restrictions on the use of negative TRIMs, and the EU, on the other hand, which had a less ambitious list of prohibited TRIMs). 
repair through the adoption of specific and unambiguous rules on certain trade-distorting investment measures, in particular local content requirements. 237

What is a trade-related investment measure or "TRIM?" A TRIM is any measure imposed by a government (usually, but not exclusively, a developing country) on a foreign investor (often, but not always, a multinational enterprise) as a condition for investing in the host country. TRIMs can be positive or negative. Examples of positive TRIMs (investment incentives) include financial incentives, such as tax holidays or subsidies, to invest within the host country generally or within certain economically depressed regions of the host country specifically.238 Examples of negative TRIMs (performance requirements) include local equity requirements, licensing requirements, profit remittance restrictions, foreign exchange restrictions, transfer-of-technology requirements, domestic sales requirements, trade-balancing requirements, localcontent requirements, export requirements, and importsubstitution requirements. 239

The TRIMs Agreement deals exclusively with negative TRIMs and addresses only a handful of the most egregious trade-related investment measures. The Agreement has three main features. First, it identifies certain types of investment measures that are inconsistent with GATT. Article 2.1 of the TRIMs Agreement stipulates that "no Member shall apply any TRIM that is inconsistent with the provisions of Article III or Article XI of GATT 1994."240 Article 2.2 refers to the illustrative list of TRIMs that are inconsistent with Articles III:4 and XI:1 of GATT 1994.241 The TRIMs Annex provides that measures must be mandatory, that is, enforceable under domestic law or under administrative rulings, or

237 See GATT Dispute Panel Report on Canada, Canada-Administration of the Foreign Investment Review Act, Feb. 7, 1984, GATT B.I.S.D. (30th Supp.) at 140 (1980) (holding that undertakings between investors and the Canadian government regarding domestic content were incompatible with GATT Article III).

238 See WORLD INVESTMENT REPORT 1996, supra note 10, at 180 (listing "[m]ain types of incentive measures offered to foreign investors").

$239 \mathrm{Id}$. at 179 . For an inventory of performance requirements, see WTO Committee on Trade-Related Investment Measures, Joint Study by the WTO and UNCTAD Secretariats, Trade-Related Investment Measures and Other Performance Requirements, G/C/W/307 (Oct. 1, 2001). The World Bank also takes a dim view of performance requirements. See World Bank, Guidelines on the Treatment of Foreign Direct Investment, 31 I.L.M. 1379 (1992).

240 TRIMs Agreement, supra note 235, art. 2.1, at 1448 .

241 See id. art. 2.2, at 1448. 
compliance with which is necessary to obtain an advantage.242 Next, these mandatory measures are prohibited if they require the purchase or use of domestic products (i.e., local content requirements); limit the purchase or use of imported products to an amount related to the volume or value of local products that are exported (i.e., trade-balancing requirements); or tie access to foreign exchange to an investor's foreign exchange earnings (i.e., foreign exchange balancing restrictions). ${ }^{243}$ The prohibited measures listed in the Illustrative Annex to the TRIMs Agreement underscore the close link between foreign investment and international trade. The prohibitions of the TRIMs Agreement apply equally to measures imposed on domestic firms, not just on foreign investments, and cover both new and existing investments. ${ }^{244}$

\section{Id. Annex, at 1452.}

243 Id. For a study of the impact on international investment and trade flows of local content requirements, export performance requirements, and trade balancing requirements, see WTO Council for Trade in Goods, Joint Study by the WTO and UNCTAD Secretariats, Trade-Related Investment Measures and Other Performance Requirements 21-26, G/C/W/307/Add.1 (Feb. 8, 2002).

244 See MCGOVERN, supra note 64, at 8.24-1 (noting that the TRIMs Agreement "is not limited to measures in regard to foreign investment. Measures that are aimed at encouraging local manufacturing capability are investment measures") (footnote omitted). See also WTO Dispute Panel on Indonesia, Certain Measures Affecting the Automobile Industry, WT/DS54/R (July 2, 1998). In 1993, Indonesia established a car program (modified and expanded in 1996) that was designed to foster and promote a local automobile industry. The car program provided for local content requirements linked to certain tax benefits for completed cars incorporating a certain percentage value of domestic products, and to customs duty benefits for imported parts and components used in cars incorporating a certain percentage value of domestic products. The United States, Japan, and the EU complained that the car program violated Article 2 of the TRIMs Agreement and GATT Article III:4. (Despite the transition period that developing countries have under the TRIMs Agreement, the complaint was nevertheless filed against Indonesia because the measures at issue were introduced after the effective date of the TRIMs Agreement.). The WTO panel agreed, finding that tax and tariff benefits made contingent upon meeting local content requirements under the car program constitute "advantages" within the meaning of the Illustrative List to Article 2 of the TRIMs Agreement, and thus violate Article 2.1 of the Agreement. See id. para. 14.91. See also WTO Dispute Panel on India, Quantitative Restrictions on Imports of Agricultural, Textile and Industrial Products, Measures Affecting the Automotive Sector, WT/DS90/R (Dec. 21, 2001) (holding that an obligation to use a certain portion of local parts and components in the manufacture of cars violates Article III:4), appeal withdrawn by India, WTO Appellate Body on India, Measures Affecting the Automotive Sector, para. 14.91, WT/DS146/AB/R (Mar. 19, 2002).

A similar TRIMs dispute between the United States and the Philippines was eventually resolved through a mutually agreed solution. See Daniel Pruzin, U.S. to Refrain from Pursuing TRIMs Panel on Philippine Cars While Nations Seek Deal, 17 Int'l Trade Rep. (BNA), No. 46, at 1777 (Nov, 23, 2000). At issue was the Philip- 
Second, the Agreement requires that all inconsistent TRIMs be notified and eliminated in two years in the case of developed countries, five years in the case of developing countries, and seven years in the case of least-developed countries. ${ }^{245}$ A time extension is possible under Article 5.3 if a developing country or leastdeveloped country member "demonstrates particular difficulties in implementing the provisions of this Agreement." 246 In order not to disadvantage established enterprises that are subject to a TRIM relative to new investments that are exempt from it, under Article 5.5, members may apply the same TRIM to new investments during the transition period, where the existing and new investment produce like products. 247

Third, in a small victory for developing-country members, the Council for Trade in Goods was to review the operation of the TRIMs Agreement by the end of 1999. As part of the Council's review, the Council was to "consider whether the Agreement should be complemented with provisions on investment policy and competition policy." 248 The TRIMs Agreement's built-in agenda thus dovetails into the work of the two Working Groups established in the 1996 Singapore Ministerial Conference meeting to examine the issues of trade and foreign investment and trade and competition policy. 249

The TRIMs Agreement does not address key FDI issues, such as the right of establishment, repatriation of profits, or technology transfer. The TRIMs Agreement does, however, mark the first suc-

pine government's Motor Vehicle Development Program that allowed manufacturers based in the Philippines to import parts and finished vehicles at preferential duty rates, provided the manufacturers met local content requirements and earned foreign exchange needed to buy imported parts by exporting completed vehicles.

245 See TRIMs Agreement, supra note 235, art. 5, at 1449.

246 In 2000, eight developing countries (Argentina, Chile, Colombia, Malaysia, Mexico, Pakistan, the Philippines, and Romania) sought an extension of the five-year period within which to eliminate all prohibited TRIMs. In 2001, they were granted a waiver of the obligation to comply with the TRIMs Agreement's transition period until December 31, 2001, with a possible second extension until December 31, 2003. See, e.g., WTO, Extension of the Transition Period for the Elimination of Trade-Related Investment Measures Notified under Article 5.1 of the Agreement on Trade-Related Investment Measures, Argentina, G/L/460 (Aug. 7, 2001). See also Ravi Kanth, WTO Approves Extending Deadline for TRIMS Compliance for Eight Members, 18 Int'l Trade Rep. (BNA) 1255 (Aug. 9, 2001).

247 See TRIMs Agreement, supra note 235, art. 5.5, at 1449.

248 Id. art. 9, at 1451.

249 See infra notes 257-74 and accompanying text. 
cessful attempt made within the GATT-WTO system to facilitate foreign investment by eliminating non-tariff barriers to trade in goods associated with foreign investment. The Agreement is designed to ensure that governments do not apply measures to foreign investment that create restrictions on trade in goods. It gives investors the assurance that they may freely buy, sell, import, and export goods that are produced in countries outside the country in which their investment is located. At the same time, however, the TRIMs Agreement may have been a solution in search of a problem. It is reported, for example, that only $6 \%$ of all overseas affiliates of U.S. companies are affected by TRIMs. ${ }^{250}$ It is also reported that most TRIMs have little effect on managers' behavior because they would have made most of the same decisions with or without local investment measures to influence or guide their decisionmaking., 251

Moreover, the practices that the TRIMs Agreement does address could have been dealt with under existing GATT rules. The negative TRIMs listed in the Illustrative Annex all violate GATT Articles III and XI with or without a TRIMs Agreement stating that they do. ${ }^{252}$ The TRIMs Agreement is, in effect, a codification of GATT jurisprudence - a restatement of existing GATT rules. ${ }^{253}$ The absence of a strong dispute settlement mechanism under GATT 1947 probably explains why more TRIMs were not challenged under GATT 1947.254

Finally, two areas where a TRIMs Agreement is silent are restrictive business practices and positive TRIMs. As part of the WTO's built-in agenda, Article 9 of the TRIMs Agreement calls for a five-year review of the Agreement (i.e., in 1999) to consider whether it should be complemented with provisions on investment and competition policy. ${ }^{255}$ Two WTO Working Groups were established in 1997 to examine the relationship between trade and in-

250 See EVANS \& WALSH, supra note 66 , at 32.

251 Id.

252 See MCGOVERN, supra note 64, at 8.24-1 (" $[1]$ t is difficult to think of circumstances in which liability could arise under [GATT Articles III or XI] but not under [the TRIMs Agreement].").

253 See Mashayekhi, supra note 19, at 239 "It prohibits those measures which are prohibited by GATT Article[s] III.").

254 The U.S. complaint against Canada's Foreign Investment Review Act is a notable exception. See GATT Dispute Panel on Canada, Canada-Administration of the Foreign Investment Review Act, supra note 237.

255 See TRIMs Agreement, supra note 235, art. 9, at 1449. 
vestment and between trade and competition policy over a twoyear period. ${ }^{256}$ A brief review of the work of the Working Group on the Relationship Between Trade and Investment follows.

\section{THE WTO WORK PROGRAM ON THE TRADE-INVESTMENT RELATIONSHIP}

As the foregoing discussion has attempted to demonstrate, existing WTO rules and agreements do address investment issues more than just incidentally. In an attempt to build on the foundation that had been laid both in the Uruguay Round and in postUruguay Round negotiations, the Ministerial Declaration issued at the conclusion of the 1996 Singapore Ministerial Conference called for the establishment of two Working Groups, one on trade and investment and the other on trade and competition policy. The Declaration provides:

Having regard to the existing WTO provisions on matters related to investment and competition policy and the builtin agenda in these areas, including the TRIMs Agreement, and on the understanding that the work undertaken shall not prejudge whether negotiations will be initiated in the future, we also agree to:

- establish a working group to examine the relationship between trade and investment; and

- establish a working group to study issues raised by Members relating to the interaction between trade and competition policy, including anti-competitive practices, in order to identify any areas that may merit further consideration in the WTO framework. 257

The Singapore Ministerial Declaration expresses some ambivalence about the direction of the Working Group on the Relationship Between Trade and Investment ("WGTI"), stating that the Working Group's mandate does not prejudge whether or not future negotiations on a WTO investment agreement will be

256 See infra notes 258-60 and accompanying text.

257 Singapore Ministerial Declaration, adopted on 13 December 1996, para. 20, WT/MIN(96)/DEC (Dec. 18, 1996). 
launched, and that any future negotiations will take place only after an explicit consensus decision by WTO members regarding such negotiations. ${ }^{258}$

The substantive work performed by the WGTI has included (1) studying the relationship between trade and investment for development and economic growth; (2) studying the economic relationship between trade and investment; and (3) conducting a stocktaking and examining the implications of existing international instruments and activities regarding trade and investment.259

Many of the contributions to the WGTI note that the linkages between trade and foreign investment are several and assert that the effects of investment for host country and investor country alike are beneficial. In this respect, the views of the OECD, the WTO, and UNCTAD on the benefits of FDI in facilitating economic growth, technological innovation, and competitiveness have converged. For example, the OECD noted the beneficial effects of FDI in the following 1998 communication to the WGTI:

Direct investment by MNEs [multinational enterprises] has the potential rapidly to restructure industries at a regional or global level and to transform host economies into prodigious exporters of manufactured goods or services to the world market. In so doing, FDI can serve to integrate na-

258 Id. The Singapore Ministerial Declaration also directs the Working Group to cooperate with UNCTAD to ensure that the development dimension of the Working Group's terms of reference is taken into account. Id. For a summary of UNCTAD's work on a possible multilateral framework on investment, see WORLD INVESTMENT REPORT 1998, supra note 10, at 73.

259 See WTO Working Group on the Relationship Between Trade and Investment, Report (1997) to the General Council, WT/WGTI/1/Rev.1 (Dec. 9, 1997) (reporting topics discussed during various 1997 meetings); WTO Working Group on the Relationship Between Trade and Investment, Report (1998) of the Working Group on the Relationship Between Trade and Investment to the General Council, WT/WGTI/2 (Dec. 8,1998 ) (discussing substantive work done by the group in 1998); WTO Working Group on the Relationship Between Trade and Investment, Report (1999) of the Working Group on the Relationship Between Trade and Investment to the General Council, WT/WGTI/3 (Oct. 22, 1999) (discussing substantive work done by the group in 1999); WTO Working Group on the Relationship Between Trade and Investment, Report (2000) of the Working Group on the Relationship Between Trade and Investment to the General Council, WT/WGTI/4 (Nov. 27, 2000) (discussing substantive work done by the group in 2000); WTO Working Group on the Relationship Between Trade and Investment, Report (2001) of the Working Group on the Relationship Between Trade and Investment to the General Council, WT/WGTI/5 (Oct. 22, 2001) (discussing substantive work done by the group in 2001). 
tional markets into the world economy far more effectively than could have been achieved by traditional trade flows alone. As with private sector investment more generally, the benefits from FDI are enhanced in an environment characterized by an open trade and investment regime, an active competition policy, macroeconomic stability and privatization and deregulation. In this environment, FDI can play a key role in improving the capacity of the host country to respond to the opportunities offered by global economic integration, a goal increasingly recognized as one of the key aims of any development strategy. 260

The WTO Secretariat echoed the OECD's conclusions and offered some of its own insights on the importance of FDI:

Despite the difficulties associated with the measurement of the efficiency-enhancing effects induced by FDI, let alone with the assessment of the specific channels by which a transfer of technology affects local productivity, the empirical literature offers some important conclusions. First, there appears to be a wide consensus that FDI is an important, perhaps even the most important, channel through which advanced technology is transferred to developing countries. Second, there also seems to be a consensus that FDI leads to higher productivity in locally-owned firms, particularly in the manufacturing sector. Third, there is evidence that the amount of technology transferred through FDI is influenced by various host industry and host country characteristics. More competitive conditions, higher levels of local investment in fixed capital and education, and less

${ }^{260}$ WTO Working Group on the Relationship Between Trade and Investment, Communication from the OECD, Foreign Direct Investment and Economic Development 4-5 WT/WGTI/W/26 (Mar. 23, 1998). See also OECD, Open Markets Matter: The Benefits of Trade and Investment Liberalisation (Policy Brief, Oct. 1999) (discussing the benefits of trade and investment liberalization). For similar views on the positive relationship between trade and investment, see WTO Working Group on the Relationship Between Trade and Investment, Communication from Japan, WT/WGTI/W/11 (Nov. 3, 1997). 
restrictive conditions imposed on affiliates appear to increase the extent of technology transfers. ${ }^{261}$

Foreign direct investment thus plays an important role as an engine of world growth and increased globalization. According to UNCTAD, "global integration seems to have proceeded faster through FDI than through trade." 262

Benefits accrue to both the host country and home country from foreign direct investment. For investor countries the benefits of FDI include facilitation of international trade, product specialization, and the stimulation of innovation. ${ }^{263}$ The effects of outbound FDI on home country trade can be positively related. In the case of the United States, for example, U.S. exports tend to be positively associated with U.S. direct investment abroad. The explana-

261 Trade and Foreign Direct Investment, supra note 11, at 19 (footnotes omitted). UNCTAD added in its 1997 WORLD INVESTMENT REPORT that a liberal FDI regime must be complemented and supported by rules on competition:

[FDI] continues to be a driving force of the globalization process that characterizes the modern world economy. The current boom in FDI flows, which has been accompanied by increasing flows of foreign portfolio equity investments, underscores the increasingly important role played by transnational corporations (TNCs) in both developed and developing countries. This role has been facilitated by the liberalization of FDI policies that has taken place in many countries in recent years, as part of an overall movement toward more open and market-friendly policies. However, reaping the benefits of FDI liberalization requires not only that barriers to FDI are reduced and standards of treatment established - the focus of most FDI liberalization to date-but also that competition in markets is maintained.

UNCTAD, WORLD INVESTMENT REPORT 1997: TRANSNATIONAL CORPORATIONS, MARKET STRUCTURE AND COMPETITION POLICY XV (1997) [hereinafter WORLD INVESTMENT REPORT 1997]. See also WTO Working Group on the Relationship Between Trade and Investment, Note by the Secretariat, The Effects of Foreign Direct Investment on Development: Technology and Other Know-How Transfers and Spillovers, WT/WGTI/W/65 (Nov. 20, 1998) [hereinafter Note by the Secretariat] (noting the beneficial effects of technology transfers); WTO Working Group on the Relationship Between Trade and Investment, Communication from Korea, Foreign Direct Investment and Transfers of Technology, WT/WGTI/W/11 (May 30, 2000) (noting the beneficial effects of technology transfers); WTO Working Group on the Relationship Between Trade and Investment, Communication from Japan, Investment Rules for Developing Policies, WT/WGTI/W/104 (June 12, 2001) (noting the beneficial effects of technology transfers).

262 WORLD INVESTMENT REPORT 1998, supra note 10, at 7.

263 See WTO Working Group on the Relationship Between Trade and Investment, Relationship Between Investment and Competition Policy, Communication from the United States, at 3, WT/WGTI/W/55 (Sept. 25, 1998). 
tion for this relationship is that during the 1990 s nearly $30 \%$ of U.S. exports were exports of U.S. parent firms to their foreign affiliates. ${ }^{264}$ Thus, if affiliate activity increases, and the ratio of affiliate sales to parents' exports to affiliates remains constant, U.S. exports will increase as well.

Several empirical studies have been conducted to determine whether the trade relationship between an MNE and its foreign affiliates is complementary, that is, are U.S. exports from the parent firm used as intermediate goods in the affiliate's production, or whether the trade relationship is one of substitution, that is, do affiliate sales in third-country markets displace U.S. exports that would have otherwise gone to those markets? One would expect exports of the parent firm to third-country markets to be reduced if those markets are now served by the foreign affiliate. In the aggregate, whether FDI leads to rises or declines in U.S. exports depends on whether the complementarity effects outweigh the substitution effect. Studies generally have found complementarity between trade and FDI. ${ }^{265}$ All studies that have examined the impact of outbound FDI on the export trade of the home country agree that at most the net effect is not very pronounced.266 First, local production in the host country displaces exports of finished goods from the home country, but at the same time creates demand for intermediate products used by the foreign affiliate. Second, local production of one product line may generate demand for the other product lines of the parent company. Third, local affiliates often engage in the marketing of the parent's entire product line, thereby improving the competitive position of the foreign investor vis-à-vis local firms and exporters from other countries. ${ }^{267}$

The economic benefits of FDI for host countries include the efficient use of host-country resources, technology transfer to the host country (including organizational and managerial skills), positive employment effects (job creation) in the host country, and im-

264 Examination of U.S. Inbound and Outbound Direct Investment 2-6, 5-5, USITC Pub. 3383 (Jan. 2001) (discussing effect of U.S. direct investment abroad on U.S. imports).

265 See id. at 2-7 (examining the effects of inbound and outbound U.S. direct investment); Note by the Secretariat, supra note 261, at 17 (using statistical testing of spillovers to understand the impact of FDI).

266 Note by the Secretariat, supra note 261 , at 17.

267 See id. (noting changes in the market shares of foreign and local firms). 
proved productivity of local firms. ${ }^{268}$ Studies that have examined the effects of inbound FDI and the export trade of the host country show that inbound FDI contributes positively to the export performance of developing countries. It does so directly through the export activities of MNEs and indirectly by reducing the costs of domestic firms to begin or expand exporting. ${ }^{269}$

Two types of investment policies that can affect trade are investment incentives and performance requirements. Investment incentives typically do not play a fundamental role in the investment decision, unlike factors such as infrastructure, market size, production costs, and the skill-level of the local workforce. Nevertheless, all other things being equal, investment incentives do appear to influence foreign investors in their investment decision. 270

Countries that maintain high trade barriers and those that maintain low trade barriers both attract FDI, but of different types. FDI to countries with a protected market tend to be stand-alone production units that serve the domestic market. Countries with an open trade policy attract vertical FDI. The WTO Secretariat concludes that on average, countries with an open trade regime attract more FDI than protectionist countries. ${ }^{271}$ Countries with a more outward-oriented approach to trade experience a significant positive effect on GDP growth from FDI inflows, whereas inwardoriented countries experience no GDP growth from FDI inflows. ${ }^{272}$

268 See Open Markets Matter, supra note 260, at 29 (stating that "well functioning systems of innovation and technology diffusion are proving essential to ... job creation," among other things).

269 See id. (discussing the export activities of small and medium sized enterprises).

270 See $i d$. at 25 (discussing the importance of trade and investment, and its impact on the world economy).

271 See Note by the Secretariat, supra note 261 , at 4 (detailing the preference for FDI in technologically developed industries).

272 Id. The parallel working group established at the Singapore Ministerial Conference, the Working Group on the Interaction Between Trade and Competition Policy, also has reported that open policies toward FDI and properly functioning competition polices are mutually supportive. Liberal investment rules make markets contestable, thereby challenging domestic oligopolies and reducing the likelihood of cartels and monopolies. At the same time, effective competition polices can ensure against possible abuses of market power by foreign investors. Thus, for example, with open investment rules in place, an exporter unable to penetrate a foreign market because incumbent wholesalers and retailers, owned or controlled by local producers of competing goods, will not handle the exporter's goods could establish a new distribution channel or purchase an existing one, thereby eliminating the local distribution bottleneck. A liberal investment policy, in short, can simultaneously promote competition and trade in the host- 
In sum, a few general principles emerge from the work of the WGTI on the trade-investment relationship. First, a policy of open investment appears to undergird a liberal trade policy by encouraging the movement of capital to markets where competition is then either introduced or increased, and resources can then be used more efficiently and transformed into goods and services for local and worldwide distribution. Second, an open investment climate-while not the sole determinant of whether an investment will be made, but clearly an essential one-greatly increases the chances for new market entrants, and with them, increased competition. ${ }^{273}$

country market, and perhaps in the global market as well. See WTO Working Group on the Interaction Between Trade and Competition Policy, Report (1999) of the Working Group on the Interaction Between Trade and Competition Policy to the General Council 24, WT/WGTCP/3 (Oct. 11, 1999); WTO Working Group on the Interaction Between Trade and Competition Policy, Communication from the United States, Relationship Between Investment and Competition Policy, at 4, WT/WGTCP/W/102 (Sept. 25, 1998) (addressing the relationship between investment and competition policy).

273 The factors that determine whether a firm (predominantly a multinational enterprise or "MNE") will make a foreign direct investment can be summarized using what is known as the "OLI" theory, i.e., that factors of $(O)$ wnership, (L)ocation, and (I)nternalization. See John H. Dunning, Trade, Location of Economic Activity and the MNE: $A$ Search for an Eclectic Approach, in THE INTERNATIONAL ALLOCATION OF ECONOMIC ACTIVITY: PROCEEDINGS OF A NOBEL SYMPOSIUM HELD AT STOCKHOLM 395-418 (B. Ohlin et al. eds., 1977) (discussing the impact of FDI undertaken by MNEs); UNCTAD, WORLD INVESTMENT REPORT 2000: CROSS-BORDER MERGERS AND ACQUISITIONS AND DEVELOPMENT 141-42 (2000) [hereinafter WORLD INVESTMENT REPORT 2000]. Regarding the first factor, ownership, the firm may own intangible assets (e.g., intellectual property, management know-how, marketing networks) that can be profitably exploited on a comparatively large scale. Under the second factor, location, firms that produce goods can minimize production costs by dividing production among countries rather than producing in and exporting from the home country exclusively. The third factor, internalization, focuses on whether the profits to be earned by exploiting the assets within the company are greater than licensing the use of those assets to a foreign firm. In the view of MNEs, technological advantages are what gives them an edge over domestic competitors, followed by marketing and managerial assets. See GILLES Y. BERTIN \& SALLY WYATT, MULTINATIONALS AND INDUSTRIAL PROPERTY: THE CONTROL OF THE WORLD'S TECHNOLOGY 25-29 (1988) (discussing the impact of technology on the world economy). Thus, if an MNE licensed its intellectual property, it would be revealing details of an important asset to the licensee. By entering into a licensing agreement an MNE would lose the control that outright equity ownership of a foreign affiliate would provide. Such an agreement would also give the licensee valuable information that could make it a future competitor of the MNE in countries where enforcement of intellectual property rights is weak. The licensee also might not possess the skills necessary to work the technology that is transferred under the licensing agreement. For these reasons, an MNE might conclude that there is greater profit potential in making an FDI rather than licensing to a foreign 
Thus, an open and hospitable climate for foreign investment can increase the general welfare of both the host and home country, can promote economic efficiency, can stimulate competition among firms nationally and transnationally, and can ultimately benefit consumers both in the host country and abroad in the form of lower prices for goods and services. Third, an open investment climate not only increases competition in markets for goods and services that are tradable across borders, but it also makes markets more competitive for services that are local and immovable. Fourth, a liberal investment climate can also mitigate or eliminate local distribution bottlenecks that might prevent competition, especially in situations where local manufacturers own local distribution networks. ${ }^{274}$

Despite the force of the economic arguments for FDI as an engine of growth and development, is a WTO agreement on investment a solution in search of a problem? Is internalization - relying on national laws and bilateral and regional agreements to promote FDI inflows - preferable to globalization that looks to a multilateral agreement as the legal vehicle for facilitating FDI? As explained in the next Section, an internalization response to FDI is superior to a globalization approach.

\section{A WTO AGREEMENT ON INVESTMENT: A SOLUTION IN SEARCH OF A PROBLEM?}

A WTO agreement on investment is a solution in search of a problem for the following reasons. First, FDI flows are steadily increasing, even in the absence of a multilateral investment agree-

firm. See Trade and Foreign Direct Investment, supra note 11, at 9-10. In addition, the market for the MNE's other products might be favorable in the host country and a potential licensee or local distributor might not have the skills to effectively market them. The benefits of keeping the assets in-house, however, must exceed the costs of managing a larger, geographically dispersed organization located in different legal and cultural settings. For more on the internalization factor, see Oliver E. Williamson, MARKETS AND HierarCHIES, ANAlysis aND ANTTTRUST IMPLICATIONS: A STUDY IN THE ECONOMICS OF INTERNAL ORGANIZATION (1975); WTO Working Group on the Relationship Between Trade and Investment, Note by the Secretariat, The Relationship Between Trade and Foreign Direct Investment, at 3, WT/WGTI/W/7 (Sept. 18, 1997).

For a survey of the reasons why firms engage in foreign direct investment, and the perceived benefits and costs of FDI, see Trade and Foreign Direct Investment, supra note 11, at 8, 15-17.

274 See WTO Working Group on the Interaction Between Trade and Competition Policy, Report to the General Council; at 40, WT/WGTCP/2 (Dec. 8, 1998). 
ment. 275 Second, the threat to national sovereignty that a WTO agreement on investment represents to developing countries is a genuine concern.276 Third, the development concerns of developing countries and their capacity (or incapacity) to absorb yet another WTO agreement cannot be ignored. ${ }^{277}$ Fourth, it is safe to predict that many exceptions and reservations will be made to any WTO agreement on investment, effectively hollowing it out.278 Fifth, an incremental, sectoral approach, i.e., a GATS approach, is a tested and proven approach at the WTO for successfully negotiating market liberalization for foreign investment.279 Sixth, the most pressing issue facing the WTO membership in the context of FDI is not a lack of market access for foreign capital. ${ }^{280}$ The immediate problems are TRIMs, both positive and negative, that potentially distort investment patterns. Seventh and finally, it is far from clear that the current network of bilateral and regional investment agreements provides an unstable and unpredictable legal environment for FDI.281

Each of these seven points is discussed below.

\subsection{FDI Flows Are Increasing Annually, Not Decreasing}

First of all, it is far from clear that there is a need for an international investment agreement if one takes into consideration the views of the international investment community. Private investors as a group have not complained about a lack of access to foreign markets for their capital because of restrictive foreign investment laws. Because the demand for foreign capital outstrips the supply, it is a seller's market for investment capital, thus creating incentives for countries to liberalize their markets autonomously for foreign investment without being prodded to do so by a multilateral agreement. ${ }^{282}$ This is especially true for developing coun-

275 See infra notes 282-97 and accompanying text.

276 See infra notes 298-309 and accompanying text.

27 See infra notes 310-31 and accompanying text.

278 See infra notes 332-39 and accompanying text.

279 See infra note 340 and accompanying text.

280 See infra notes 341-70 and accompanying text.

281 See infra notes 371-86 and accompanying text.

282 WTO Working Group on the Relationship Between Trade and Investment, Communication from India , at 2, WT/WGTI/W/74 (Apr. 13, 1999). 
tries: with decreased flows of foreign aid, there is a heightened urgency to attract FDI as a substitute..$^{283}$

Even if investors are prevented from moving capital to a sector of a foreign country that is closed to them because of national laws prohibiting foreign investment, is the right answer to throw a multilateral agreement on investment at the problem? Has the absence of such an agreement stifled foreign capital flows to host countries? The statistics indicate that, on the contrary, the flow of foreign capital to overseas destinations has been rapid and has only slowed in the face of a global recession. As the following table shows, FDI has steadily increased year over year to developedcountry host countries. Importantly from a development perspective, developing countries generally have received a steadily increasing amount of FDI annually as well, although as a percentage of worldwide FDI inflows, developing countries' share has decreased in recent years. 284

283 See Mashayekhi, supra note 19, at 236 (" $[W]$ ith the reduction of official aid, countries' need for private investment has increased.").

284 The dramatic percentage decline in 1998 is attributable to the Asian financial crisis. See UNCTAD, WORLD INVESTMENT REPORT 1999: FOREIGN DIRECT INVESTMENT AND THE CHALLENGE OF DEVELOPMENT xx (1999). As a percentage of gross domestic product, FDI inflows represented 7.6\% of GDP in developed countries in 1996. The comparable figure for developing countries was $15.6 \%$, double that of developed countries. See WORLD INVESTMENT REPORT 1998, supra note 10, at 399-400 annex tbl. B.6. 
Table 1: FDI Inflows Based on UNCTAD \& World Investment Report 1998, 1999, 2000, 2001 (in billions)

\begin{tabular}{|l|l|l|l|}
\hline & $\begin{array}{l}\text { FDI Inflows to } \\
\text { Developed } \\
\text { Countries }\end{array}$ & $\begin{array}{l}\text { FDI Inflows to } \\
\text { Developing } \\
\text { Countries }\end{array}$ & $\begin{array}{l}\text { Developing Coun- } \\
\text { tries' Percentage } \\
\text { Share of Total FDI } \\
\text { Inflows }\end{array}$ \\
\hline 1992 & $\$ 120.3$ & $\$ 51.1$ & 30 \\
\hline 1993 & $\$ 138.9$ & $\$ 72.5$ & 34 \\
\hline 1994 & $\$ 141.5$ & $\$ 95.6$ & 40 \\
\hline 1995 & $\$ 211.5$ & $\$ 105.5$ & 33 \\
\hline 1996 & $\$ 195.4$ & $\$ 129.8$ & 40 \\
\hline 1997 & $\$ 233.1$ & $\$ 148.9$ & 39 \\
\hline 1998 & $\$ 460$ & $\$ 166$ & 27 \\
\hline 1999 & $\$ 636$ & $\$ 208$ & 21 \\
\hline 2000 & $\$ 1,053$ & $\$ 247$ & 19 \\
\hline 2001285 & $\$ 510$ & $\$ 225$ & 31 \\
$($ est.) & & & \\
\hline
\end{tabular}

UNCTAD reports that in the case of the forty-nine leastdeveloped countries ("LDCs"), as a group FDI increased from an annual average of $\$ 0.6$ billion during 1986-1990 to an annual average of $\$ 3.6$ billion during the latter half of the 1990s. ${ }^{286}$ In 1999, FDI flows to LDCs reached more than $\$ 5$ billion.287 For the period 19861999 as a whole, the average annual growth rate of FDI to LDCs has been $20 \% .288$ This growth rate was broad-based: twenty-seven

285 See Daniel Pruzin, U.N. Agency Cites Sharp Drop in Global Foreign Investment for 2001, 18 Int'l Trade Rep. (BNA) 1512 (Sept. 27, 2001) (projecting figures with respect to the fall in FDI).

286 See UNCTAD, FDI IN LEAST DEVELOPED COUNTRIES AT A GLANCE 1 (2001) [hereinafter FDI IN LEAST DEVELOPED COUNTRIES] ("FDI flows to the 49 LDCs as a group increased from an annual average of $\$ 0.6$ billion during 1986-1990 to an annual average of $\$ 3.6$ billion during the latter half of the $1990 \mathrm{s.}$.). lion).

287 See id. ("In 1999, FDI flows increased further, to reach more than $\$ 5$ bil-

288 See id. ("[T]his represents an average annual growth rate of 20 per cent, compared to 22 per cent for developing countries as a group."). Investment flows to LDCs are still directed mainly to a few countries. In the period 1986-1990, five countries accounted for 77\% of FDI inflows. However, in the period 1996-1999, that percentage had declined to $50 \%$. Id. at 7 . 
LDCs experienced an average annual growth rate of more than $20 \%$ and another eight LDCs of between $10 \%$ and $20 \% .289$

Of course, despite these impressive statistics, there is no control group to test the counterfactual of what the global economy would look like with a multilateral agreement on investment in place. Had a multilateral agreement on investment been in place, query whether certain foreign investments that were not made would have been made. UNCTAD concedes that it is difficult to predict how much difference a multilateral framework agreement on investment would make in terms of the quantity, quality, and patterns of actual FDI flows. ${ }^{290}$ What cannot be disputed as a matter of statistical fact is that in the absence of a multilateral agreement on investment, the growth of FDI has been impressive. The stock of FDI increased fourfold between 1992 and 1997, being valued in 1997 at $\$ 3.5$ trillion.291 In 1997, FDI flows increased 19\% over 1996 figures, to a record-breaking level of $\$ 400$ billion.292 In 1999, FDI grew by $25 \%$ to $\$ 827$ billion, up from $\$ 660$ billion in $1998,{ }^{293}$ with developing countries receiving $\$ 200$ billion of the total. ${ }^{294}$ By comparison, the total inflow of foreign direct investment worldwide in 1995 was $\$ 315$ billion, with $\$ 203$ billion of that figure going to developed countries. 295 The inflow of FDI into developing countries increased eleven-fold from $\$ 13$ billion in 1981 to nearly $\$ 149$ billion in 1997.296

289 See id. at 1-2 (charting LDC growth rates). More than $90 \%$ of FDI is through greenfield investment rather than through cross-border M\&A activity. Id. at 7.

290 See WORLD INVESTMENT REPORT 1998, supra note 10, at 130.

291 See id. at xvii (discussing FDI trends).

292 See id. (discussing FDI trends).

293 See Financial Indicators: Cross-Border Investments, ECONOMIST, Feb. 12, 2000, at 105 (providing FDI figures) [hereinafter Financial Indicators].

294 See Daniel Pruzin, UN Agency Says FDI Jumped by 25 Percent in ' 99 to $\$ 827$ Billion, 17 Int'l Trade Rep. (BNA) 234 (Feb. 10, 2000) (discussing FDI growth); Financial Indicators, supra note 293, at 105; Business This Week, ECONOMIST, Feb. 5, 2000, at 5 (discussing cross-border mergers and acquisitions).

295 WORLD INVESTMENT REPORT 1996, supra note 10, at 227. FDI in developed countries increased from $\$ 37$ billion in 1981 to $\$ 109$ billion in 1993 . Patrick Low \& Arvind Subramanian, TRIMs in the Uruguay Round: An Unfinished Business?, in THE URUGUAY ROUND AND THE DEVELOPING ECONOMIES, supra note 93, at 413-14.

296 WORLD INVESTMENT REPORT 1998, supra note 10, at 16. In 1996, two-thirds of FDI in developing countries went to Asia, whose FDI inflows rose $25 \%$ from 1995 to $\$ 81$ billion. See Emerging Market Indicators, ECONOMIST, Oct. 4, 1997, at 116. The growth of multinational enterprises has contributed to the tremendous increase in the volume of foreign direct investment. The FDI spurt was fueled in the 
The view among many developing countries is that growth in FDI is considered to be beneficial because it enhances economic growth, productivity, and competitiveness.297 Couple this view with the reality that the demand for foreign capital exceeds its supply, and it is easy to understand why, for those countries eager to attract foreign capital, it is incumbent upon them to create and foster a domestic legal environment that is hospitable to foreign investment, with or without the legal compulsion of a WTO investment agreement.

\subsection{Sovereignty Concerns}

What of the national sovereignty concerns expressed by developing countries insofar as their ability to regulate the activities of foreign investors? Because FDI often involves issues of significant control over a domestic firm, it raises sovereignty issues for many host countries. As noted above in connection with the discussion of the Havana Charter, Article 12 recognized the sovereignty of host nations to regulate foreign investment.298 While it is argued mostly by developing countries - that MNEs are able to engage in restrictive business practices in host countries that lead to monopoly profits, lower economic efficiency within the host country, and new barriers to entry by potential competitors, the WTO Secretariat has made the alternative argument that the entry of an MNE "might have the effect of breaking up a comfortable domestic oligopolistic market structure and stimulating competition and efficiency.... The empirical evidence, however, points strongly to pro-competitive effects." 299 Nevertheless, in instances where

last half of the decade of the 1990 s by cross-border mergers and acquisitions $(\$ 797$ billion), rather than greenfield investment in new plants and factories. See WORLD INVESTMENT REPORT 1998, supra note 10, at 16.

297 See WORLD INVESTMENT REPORT 1997, supra note 261; WORLD INVESTMENT REPORT 1996, supra note 10; Trade and Foreign Direct Investment, supra note 11. An extensive bibliography on trade and investment can be found in Trade and Foreign Direct Investment, supra note 11, at 46-53.

298 See supra notes 59-62 and accompanying text.

299 Trade and Foreign Direct Investment, supra note 11, at 16 (citing in support Richard E. CAVES, MULTINATIONAL ENTERPRISES AND ECONOMIC ANALYSIS (1982), and EDWARD M. Graham, Global Corporations and National GOVERNMENTS (1996)). The United Nations prepared a non-binding Draft Code of Conduct on Transnational Corporations that dealt in part with restrictive business practices of MNEs. For the similarities and differences between the Draft Code and the OECD Guidelines on Multinational Enterprises, see WTO Working Group on the Relationship Between Trade and Investment, Communication from 
MNEs do engage in restrictive business practices in the host country, how are developing countries that lack the human and technical capacity to combat such practices? ${ }^{300}$ For developing countries and for countries with economies in transition, enacting and implementing competition legislation can be a formidable task. ${ }^{301}$ The many hurdles facing developing countries in implementing a competition law regime include developing a skilled staff and securing the financial resources needed to administer and implement competition legislation. Small developing countries face a scarcity of skilled human resources, making it difficult for them to participate in international meetings and negotiating fora in which they must be present simultaneously. Developing a culture of competition also presents a challenge for businesses with little or no knowledge of competition law and its impact. 302 They must be educated. ${ }^{303}$

UNCTAD, The Draft United Nations Code of Conduct on Transnational Corporations and the $O E C D$ Guidelines for Multinational Enterprises: Similarities and Differences, WT/WGTI/W/52 (Aug. 21, 1998).

300 Besides the problem of MNEs dominating local markets, what about subsidiaries of MNEs that purchase inputs from their parent, rather than source inputs locally, as well as parent-imposed restrictions on a subsidiary's export markets as a way of segmenting world markets? In a related vein, what of MNE activity that can have adverse effects on development, for example, where a country has the potential to develop indigenous resources through local talent but is preempted from doing so by an MNE? In addition, developing countries are far less able to combat export cartels than are developed countries.

301 See OECD, COMPETITION LAW AND POLICY IN THE BALTIC COUNTRIES (1999); William E. Kovacic, Designing and Implementing Competition and Consumer Protection Reforms in Transitional Economies: Perspectives from Mongolia, Nepal, Ukraine, and Zimbabwe, 44 DEPAUL L. REv. 1197 (1995); William E. Kovacic, Getting Started: Creating New Competition Policy Institutions in Transition Economies, 23 BROOK. J. INT'L L. 403 (1997) (discussing processes, procedures, and policies at issue when creating new competition institutions in transition economies).

${ }^{302}$ See, e.g., WTO Working Group on the Interaction Between Trade and Competition Policy, Communication from Trinidad and Tobago, Developing and Implementing a Competition Regime: Challenges Faced by Small Open Economies, WT/WGTCP/W/143 (Aug. 2, 2000).

303 Developing countries may stand to gain from a WTO agreement that prohibits such cartel activity and that takes developing-country interests into account when cross-border mergers are reviewed. Thus, the need may exist from a developing country perspective for an international competition policy agreement with a binding dispute settlement mechanism. As far as what would be in the best interests of developing countries, Bernard Hoekman has advocated a competition policy agreement that (1) bans horizontal restraints on price fixing and market sharing, including export cartels; (2) replaces antidumping duty laws with competition laws; and (3) provides for binding WTO dispute settlement. See Bernard Hoekman, Competition Policy and the Global Trading System: A Develop- 
Of the more than eighty countries that have enacted some form of competition law, nearly forty of these are developing countries and countries with economies in transition. ${ }^{304}$ UNCTAD has concluded that "there would be substantial benefits to be obtained from strengthening the application of competition law and policy in developing and least developed countries and countries in transition in terms of greater production, allocative and dynamic efficiency, welfare and growth." 305 Those developing countries that do have competition laws in place typically are unable to apply them extraterritorially. ${ }^{306}$ In addition, having a competition law on the books and having an effective national enforcement mechanism in place are not the same thing. Developing countries that have enacted competition legislation may lack the resources and expertise to implement an effective legal regime, although a lack of capacity to pursue investigations and to bring enforcement actions is not universally the case. ${ }^{307}$ Nevertheless, competition law enforcement actions are expensive whenever they are brought. Moreover, broadly drafted legislation, coupled with agency discretion, creates an environment of legal uncertainty for businesses. One defensive (and cheap) response has been to protect local firms

ing-Country Perspective 16 (World Bank Policy Research Paper No. 1735 (1997)); Ignacio de Leon, An Alternative Approach to Policies for the Promotion of Competition in Developing Countries, 6 SW. J. L. \& TRADE AM. 85 (1999).

304 See Conference on Trade and Competition Policies, Exploring the Ways Forward, Summary, 1 OECD J. COMPETITION L. \& POL'Y 7, 8 (1999) (noting that "the majority of developing countries have enacted competition laws in the last five years"). There is an ongoing, but quiet, debate over whether traditional competition laws are appropriate for developing countries and economies in transition. See, e.g., Craig W. Conrath \& Barry T. Freeman, A Response to "The Effectiveness of Proposed Antitrust Programs for Developing Countries," 19 N.C. J. INT'L L. \& COM. REG. 233 (1994); A.E. Rodriguez \& Mark D. Williams, The Effectiveness of Proposed Antitrust Programs for Developing Countries, 19 N.C. J. INT'L L. \& COM. REG. 209 (1994) (responding to the former and acknowledging the "fierce debate" over whether it is a good or bad idea for economies in transition to market economies to adopt antitrust laws).

305 UNCTAD, Report by the UNCTAD Secretariat, Empirical Evidence of the Benefits from Applying Competition Law and Policy Principles to Economic Development in Order to Attain Greater Efficiency in International Trade and Development 2, TD/B/COM.2/EM/10/Rev.1 (May 25, 1998).

306 See Andrew T. Guzman, Is International Antitrust Possible?, 73 N.Y.U. L. REv. 1501, 1537 (1998) (discussing antitrust efforts of developing countries).

307 For a review of competition law enforcement activities of several Latin American countries (Argentina, Brazil, Colombia, Costa Rica, Jamaica, Mexico, Panama, Peru, and Venezuela), see Organization of American States, Report on Developments and Enforcement of Competition Policy and Laws in the Western Hemisphere, FTAA.ngcp/inf/04/Cor.1 (Oct. 25, 1999). 
and infant industries by restricting access of foreign investors and foreign traders to their markets. The downside is the impoverishment of the protected economy, damage to international competition, and an overall decline in aggregate world wealth.

Alternatively, one of the cheapest and most effective procompetitive devices available to any government is to adopt a liberal trade policy that will bring competitive pressure to bear on local monopolies in the form of imports. Equally important in the promotion of competition in national markets is the encouragement of foreign direct investment. The overall focus for developing countries, then, should be on a competition policy that promotes competition in local markets, rather than competition law that seeks to punish anti-competitive conduct. In short, competition in local markets can be promoted "on the cheap" through liberal trade and foreign investment policies at the national level. ${ }^{308}$ UNCTAD has warned, however, that " $[t]$ rade and foreign investment liberalization, while increasing international competition in many sectors, may enhance the incentive for firms to resort to RBPs to maintain their marker position ..." 309 Therefore, it may be too facile to conclude that developing countries need only be concerned with competition policy and not also with competition law enforcement. The countries most vulnerable to restrictive business practices are also the countries least capable of combating them, namely, developing countries.

\subsection{Development Concerns}

At the WTO's fourth Ministerial Conference held in Doha, Qatar in November 2001, the trade ministers of the WTO members devoted much of their attention to the capacity of developing countries to implement existing WTO commitments. ${ }^{310}$ Following the debacle in 1999 at the third Ministerial Conference in Seattle, developing countries, especially the LDCs, were determined not to

308 See id. at 13 , para. 37.

309 UNCTAD, Revised Study by the UNCTAD Secretariat, Review of All Aspects of the Set of Multilaterally Agreed Equitable Principles and Rules for the Control of Restrictive Business Practices, The role of competition policy in economic reforms in developing and other countries, at 7, TD/RBP/CONF.4/2 (May 26, 1995). See WTO Working Group on the Interaction Between Trade and Competition Policy, Report to the General Council 14, WT/WGTCP/2 (Dec. 8, 1998) (pointing out that trade liberalization alone would not sufficiently guarantee competition in all circumstances).

310 See infra notes 317-25 and accompanying text. 
be marginalized at the next biennial meeting of the Ministerial Conference.

Two pivotal meetings occurred in 2001 that put the spotlight at the Doha Ministerial Conference on the economic plight of LDCs. The first meeting was the Third United Nations Conference on the Least Developed Countries held in Belgium in May 2001. Out of the Conference came a document entitled Draft Programme of Action for the Least Developed Countries for the Decade 2001-2010, calling for coherent action by the United Nations, the WTO, the World Bank, and the IMF to integrate LDCs into the global economy. ${ }^{311}$ The second meeting was the LDC trade ministers' meeting held in Zanzibar, Tanzania in July 2001. In the Zanzibar Declaration the LDCs agreed to take steps to reverse the process of their exclusion and marginalization in world trade. ${ }^{312}$ The trade ministers identified no fewer than nine items that they requested the Doha Ministerial Conference to agree to, including full implementation of the commitments undertaken at the Third United Nations Conference on the Least Developed Countries and full implementation of the Integrated Framework. ${ }^{313}$ Attached to the Zanzibar Declaration was an annex entitled $L D C$ s Development Agenda at the Fourth Ministerial Conference, Negotiating Objectives and Proposals of the Least Developed Countries. ${ }^{314}$ The LDCs' agenda listed no fewer than twenty-one agenda items for Doha, including implementation issues in the areas of agriculture, services trade, subsidies, technical assistance with food and product standards, textiles and clothing, TRIMs, TRIPS, customs valuation, antidumping and countervailing duties, and safeguards. ${ }^{315}$

Speaking on behalf of a broader range of developing countries, the Group of 77, together with China, issued a separate declaration in October 2001 calling on the Ministerial Conference to, inter alia, make the special and differential treatment provisions of the WTO multilateral trade agreements "legally binding... operational-

311 See UNCTAD, Third United Nations Conference on the Least Developed Countries, Draft Programme of Action for the Least Developed Countries for the Decade 2001-2010 para. 65, A/CONF.191/L.18 (2001) (stating that "[c]oherent actions ... remain an essential element of overall policy reform).

312 See Meeting of the Ministers Responsible for Trade of the Least Developed Countries, Zanzibar Declaration, circulated by the WTO, WT/L/409 (Aug. 6, 2001) (discussing the marginalization of LDCs in the multilateral trading system).

313 See id.

314 See id.

315 See id. 
ized ... and enforceable so that these do not remain merely 'best endeavour clauses.'" 316 The Declaration also called for increased technical assistance in order to bring developing countries' laws into compliance with WTO obligations.

Around 100 implementation issues were raised prior to the Doha Ministerial Conference, either in the LDC Zanzibar Declaration, in the Draft Programme issued at the Third U.N. Conference on LDCs, or in the Group of 77 Declaration. At the Doha Ministerial Conference the trade ministers launched a "work program" that includes on its agenda many of these implementation-related issues and concerns. ${ }^{317}$ Although the trade ministers carefully avoided the use of the politically-charged phrase, "multilateral trade negotiation round," - perhaps out of a concern that it would conjure up images of the seemingly interminable eight-year Uruguay Round-the "work program" is informally known as the "Development Round." The Ministerial Declaration issued at the conclusion of the Doha session provides:

We attach the utmost importance to the implementationrelated issues and concerns raised by Members and are determined to find appropriate solutions to them .... [W]e further adopt the Decision on Implementation-Related Issues and Concerns in document WT/MIN(01)/17 to address a number of implementation problems faced by Members. We agree that negotiations on outstanding implementation issues shall be an integral part of the Work Programme we are establishing.... 318

316 Group of 77, Declaration of the Group of 77 and China on the Fourth WTO Ministerial Conference at Doha, Qatar, para. 7, circulated by the WTO, WT/L/424 (Oct. 24, 2001).

317 WTO Ministerial Conference, Fourth Session, 9-14 November 2001, Ministerial Declaration adopted on 14 November 2001, para. 12, WT/MIN(01)/DEC/W/1 (Nov. 14, 2001) [hereinafter Doha Ministerial Declaration].

318 Id. para. 12. The Declaration adds that where a specific negotiating mandate is established in the Declaration, the relevant implementation issues are to be addressed under that mandate. See id. para. 12(a). Otherwise, the other outstanding implementation issues are to be addressed as a matter of priority by the relevant WTO bodies, which shall report to the Trade Negotiations Committee by the end of 2002 for appropriate action. See id. para. 12(b). 
With regard to the specific concerns of LDCs, the Ministerial Declaration acknowledged the concerns expressed by LDCs in the Zanzibar Declaration. ${ }^{319}$ The Declaration also endorsed the Integrated Framework and reaffirmed that the special and differential (S\&D) treatment provisions are an integral part of the WTO Agreements. ${ }^{320}$ The Declaration states that "all special and differential treatment provisions shall be reviewed with a view to strengthening them and making them more precise, effective and operational. In this connection, we endorse the work programme on special and differential treatment set out in the Decision on Implementation-Related Issues and Concerns." 321 The Decision on Implementation-Related Issues and Concerns referred to in paragraph 12 of the Ministerial Declaration identifies more than forty implementation issues and proposed action by the WTO members.322 Most of the forty-plus items were settled at or before the Doha Conference.

The majority of the remaining items are the subject of negotiations that are to be concluded not later than January 1, 2005, with a stocktaking of the progress of the negotiations to take place in September 2003 at the fifth Ministerial Conference in Cancun, Mexico. ${ }^{323}$ As was the case with the Uruguay Round agreements, all agreements reached during the Doha Development Round are to be treated as a single undertaking, that is, a package deal with no opt-outs. ${ }^{324}$ This single undertaking would include, of course, an agreement on investment.

319 See id. para. 43. (recognizing that "the integration of the LDCs into the multilateral trading system requires meaningful market access, support for the diversification of their product and export base, and trade-related technical assistance and capacity building").

320 See id.

321 Id. para. 44. It was agreed in early 2002 that the review of all S\&D treatment provisions will be carried out by the Committee on Trade and Development with a view to making them more precise, effective, and operational. See WTO, Committee on Trade and Development, Report to the General Council 1, TN/CTD/3 (July 26, 2002).

322 See WTO Ministerial Conference, Fourth Session, Decision on Implementation-Related Issues and Concerns, WT/MIN(01)/W/10 (Nov. 14, 2001) (listing the decisions reached by the ministerial conference).

323 See Doha Ministerial Declaration, supra note 317, para. 45 (detailing the negotiations to take place).

324 See id. para. 47 "With the exception of the improvements and clarifications of the Dispute Settlement Understanding, the conduct, conclusion, and entry into force of the outcome of the negotiations shall be treated as part of a single undertaking."). 
Several items were identified at the Doha Ministerial Conference that are to be the subject of future trade negotiations, including agriculture, implementation issues, services, and market access for non-agricultural products. ${ }^{325}$ Also on the agenda is a possible WTO agreement on investment. Paragraphs 20 and 22 of the Doha Ministerial Declaration state:

Recognizing the case for a multilateral framework to secure transparent, stable and predictable conditions for long-term cross-border investment, particularly foreign direct investment, that will contribute to the expansion of trade..., we agree that negotiations will take place after the Fifth Session of the Ministerial Conference on the basis of a decision to be taken, by explicit consensus, at that Session on modalities of negotiations.

In the period until the Fifth Session, further work in the Working Group on the Relationship Between Trade and Investment will focus on the clarification of: scope and definition; transparency; non-discrimination; modalities for pre-establishment commitments based on a GATS-type, positive list approach; development provisions; exceptions and balance-of-payments safeguards; consultation and the settlement of disputes between Members. Any framework should reflect in a balanced manner the interests of home and host countries, and take due account of the development policies and objectives of host governments as well as their right to regulate in the public interest. The special development, trade and financial needs of developing and least-developed countries should be taken into account as an integral part of any framework, which should enable Members to undertake obligations and commitments commensurate with their individual needs and circumstances. Due regard should be paid to other relevant WTO provi-

325 See id. paras. 13-19 (detailing the work program agenda set forth in the Declaration). 
sions. Account should be taken, as appropriate, of existing bilateral and regional arrangements on investment. ${ }^{326}$

If S\&D treatment is to have any meaning, what will such treatment look like in the context of a WTO investment agreement? Will developing countries be permitted to enter into reservations and be granted exemptions under an investment agreement that in effect codifies the status quo regarding FDI? In the face of a clear recognition by the international trade community at the Doha Ministerial Conference that developing countries confront serious problems in implementing the agreements reached during the Uruguay Round, are developing countries once again to be asked to assume even more legal obligations as the price for continued WTO membership? What seems to have emerged form the Doha Ministerial Conference is that agenda items in any future multilateral trade negotiation round will be agreed to on a consensus basis and not dictated by the Quad members to developing countries. It seems quite predictable that in any WTO agreement on investment, developing countries will be accorded a great deal of flexibility in its implementation, especially in the areas of national treatment, performance requirements, and reservations excluding certain sensitive sectors from foreign investment. ${ }^{327}$ The reason why it seems quite predictable is the backdrop of some ninety-seven provisions in the WTO MTAs on S\&D treatment for developing countries, ${ }^{328}$

326 See id. paras. 20, 22.

327 See WTO Working Group on the Relationship Between Trade and Investment, Communication from UNCTAD, International Investment Agreements: Concepts Allowing for a Certain Flexibility in the Interest of Promoting Growth and Development, WT/WGTI/W/77 (May 25, 1999) (setting forth concepts designed to afford developing countries great flexibility within international investment agreements).

328 See WTO Committee on Trade and Development, Concerns Regarding Special and Differential Treatment Provisions in WTO Agreements and Decisions, Note by the Secretariat para. 4, WT/COMTD/W/66 (Feb. 16, 2000). The majority of WTO MTAs contain one or more clauses providing special and differential (S\&D) treatment of developing countries. In total, there are ninety-seven S\&D treatment provisions in the WTO agreements. The S\&D treatment provisions can be divided into six categories: (1) provisions aimed at increasing trade opportunities; (2) provisions that require WTO members to safeguard the interests of developing-country members; (3) flexibility of commitments; (4) transitional time periods; (5) technical assistance; and (6) provisions relating to measures to assist leastdeveloped country members. Id. See also WTO Committee on Trade and Development, Implementation of WTO Provisions in Favour of Developing Country Members, Note by the Secretariat, WT/COMTD/W/35 (Feb. 9, 1998) (providing 
and the MFN exemptions listed under the GATS on the grounds of culture, environment, and social objectives, ${ }^{329}$ coupled with the commitment in the Doha Ministerial Declaration that the S\&D treatment provisions are an integral part of the WTO Agreements. The Declaration states:

[A]ll special and differential treatment provisions shall be reviewed with a view to strengthening them and making them more precise, effective and operational. In this connection, we endorse the work programme on special and differential treatment set out in the Decision on Implementation-Related Issues and Concerns. 330

comprehensive information on actions taken pursuant to WTO provisions in favour of developing countries).

The MTAs covering trade in goods with S\&D treatment clauses include: (1) the Agreement on Agriculture; (2) the Agreement on Implementation of Article VI of the General Agreement on Tariffs and Trade 1994 (the Antidumping Agreement); (3) the Agreement on Subsidies and Countervailing Measures; (4) the Agreement on Safeguards; (5) the Agreement on the Application of Sanitary and Phytosanitary Measures; (6) the Agreement on Technical Barriers to Trade; (7) the TRIMs Agreement; (8) the Agreement on Implementation of Article VII of the General Agreement on Tariffs and Trade (the Valuation Agreement); (9) and the Agreement on Textiles and Clothing. BHALA \& KENNEDY, supra note 3, at 431.

In addition to the WTO MTAs covering trade in goods, three other WTO MTAs - the GATS, the TRIPS Agreement, and the Understanding on Rules and Procedures Governing the Settlement of Disputes - contain special provisions for the benefit of developing and least-developed countries. Id.

329 WTO members listed a number of GATS MFN exemptions on the grounds of cultural objectives (seventy exemptions), environment and conservation (twenty exemptions), industrial policy (forty-nine exemptions), and social objectives (fourteen exemptions). See Trade in Services: A Roadmap to GATS MFN Exemptions, supra note 94, paras. 64-77 (detailing the breakdown of the exemptions).

330 Doha Ministerial Declaration, supra note 317, para. 44. The Declaration also provides the following with regard to an agreement on investment and developing countries:

We recognize the needs of developing and least-developed countries for enhanced support for technical assistance and capacity building in this area, including policy analysis and development so that they may better evaluate the implications of closer multilateral cooperation for their development policies and objectives, and human and institutional development. To this end, we shall work in cooperation with other relevant intergovernmental organisations, including UNCTAD, and through appropriate regional and bilateral channels, to provide strengthened and adequately resourced assistance to respond to these needs.

Id. para. 21. 
If this kind of flexibility for developing countries is included in a WTO investment agreement, the main argument in support of such an agreement-predictability and stability-would be seriously undercut. ${ }^{331}$ BITs are, therefore, an attractive alternative in cases where flexibility is needed because they allow national policies to be given effect by subordinating the admission of investment to the host country's domestic laws.

\subsection{Exceptions and Reservations Will Hollow Out a WTO Agreement on Investment}

It is not hard to predict that if negotiators proceed on the basis of either a positive list approach (as directed in the Doha Ministerial Declaration) or a negative list approach (market access is generally granted in the schedules of commitments, subject to specific exceptions or reservations), then WTO members will either refuse to make market access commitments or will enter reservations to an investment agreement on the grounds of, for example, national security (e.g., the Exon-Florio Amendment or the Helms-Burton $A c{ }^{332}$ ), or the protection of cultural industries (e.g., the EU's sweeping MFN exemption for audio-visual services under GATS 333 ). Besides the reservations that developed countries might make, they would likely be joined by developing countries in the case of reservations to ensure continued state ownership and control over natural resources and transportation industries. ${ }^{334}$ Under NAFTA, which uses the negative list approach, the parties have listed reservations in Annexes that literally run for hundreds of pages. ${ }^{335}$ Query whether these same country-specific reservations will become part of a WTO agreement on investment. Employing a negative list approach, the draft MAI had some 600 pages of reservations and that was for only a few of the OECD countries. ${ }^{336}$ On

331 See supra notes 8-10 and accompanying text.

332 See supra notes $32 \& 40$.

333 USITC Examination of GATS, supra note 115, at 5-17.

334 See, e.8. NAFTA, annex III, Schedule of Mexico, reprinted in NAFTA STATEMENT OF ADMINISTRATION ACTION, supra note 26, at 1679-83 (reserving to the state the right to perform exclusively activities in the energy and transportation sectors).

335 See NAFTA, annexes I-II, reprinted in NAFTA STATEMENT OF ADMINISTRATION ACTION, supra note 26, at 1486-1678.

336 See MAI Negotiating TeXT, supra note 28, art. IX (country-specific exceptions). See generally Don Wallace, Jr. \& David B. Bailey, The Inevitability of National Treatment of Foreign Direct Investment with Increasingly Few and Narrow Exceptions, 
the other hand, if a positive list approach is used, what will be the quality and quantity of offers and commitments?

If negotiations on an agreement on investment do proceed at the WTO, the GATS positive list approach based on sector-bysector negotiations would allow WTO members to retain control over the type of FDI they wish to attract. As noted by the EU, the positive list approach "has the merit of incorporating enough flexibility to allow a gradual and progressive liberalisation of FDI, fully compatible with any development strategy adopted by WTO members." 337 A positive list approach would automatically exclude new sectors that arise as a result of technological innovation. Although a negative list approach to a comprehensive investment agreement has advantages for investment liberalization-not the least of which is that WTO members are required to list with specificity exempted sectors or industries - the experience to date with a negative list approach is that it spawns so many exemptions as to render administration of any agreement problematic. 338 In the end, both approaches enable countries to preserve discriminatory measures and exclude from foreign investment certain sectors of the economy as deemed necessary to further national development policy. 339 What is left could be nothing more than a mere shell of an agreement.

\subsection{An Incremental, Sectoral Approach Is Tested and Proven}

What lessons can be learned from the pace of liberalization efforts achieved to date under existing WTO multilateral agreements that address key dimensions of FDI, most importantly the GATS (and the two subsidiary agreements on financial services and basic telecommunications) and the TRIMs Agreement? Admittedly, neither the GATS nor the TRIMs Agreement treats the subject of FDI

31 CORNELL INT'L L.J. 615 (1998) (discussing relevant norms regarding FDI with a focus on the MAI).

337 WTO Working Group on the Relationship Between Trade and Investment, Communication from the European Community and Its Member States, Concept Paper on Modalities of Pre-Establishment, para. 20, WT/WGTI/W/121 (June 27, 2002).

338 See Sauvé \& Wilkie, supra note 16, at 11 (discussing the feasibility of the negative list approach).

339 See WTO Working Group on the Relationship Between Trade and Investment, Communication from Canada, Development Provisions, para. 9, WT/WGTI/W/131 (July 3, 2002) (stating the benefits of both positive- and negative-list approaches). 
in a comprehensive fashion. Most obviously, of course, the GATS does not address the subject of FDI by manufacturers of goods. But as explained above, ${ }^{340}$ among the four modes of supply covered by GATS, GATS provides, inter alia, for the supply of services by the service suppliers of one WTO member through a commercial presence in another WTO member, i.e., through an FDI. And, as noted, the TRIMs Agreement fails to address altogether certain national measures that could have distortive effects on global FDI inflows, namely, positive TRIMs or investment incentives.

On the other hand, the 1997 Agreements on Financial Services and Basic Telecommunications represent genuine market liberalization within these two major service sectors, including the right to establish a commercial presence. These two agreements are examples of what can be achieved using a sectoral approach that is based on reciprocity. Perhaps an incremental, sectoral approach to investment is preferable to a sweeping agreement on investment whose consequences might not be easy to predict. Progressive liberalization of services trade is part of the WTO's built-in agenda and the subject of ongoing negotiations at the WTO. Negotiations on an investment agreement should be postponed to await the outcome of the follow-on services negotiations.

\subsection{Dealing with Positive and Negative TRIMs}

The most pressing issue facing the WTO membership in the context of FDI is not a lack of market access for foreign capital. The immediate problem is the one of TRIMs, both positive and negative, that potentially distort investment patterns. The TRIMs Agreement prohibits, inter alia, the most egregious internal and border measures that force investors to source inputs locally. Despite the benefits of FDI and the tremendous growth worldwide in FDI, host-country barriers still exist in the form of performance requirements. ${ }^{341}$ The most common restrictions include measures relating to admission and establishment (e.g., investment notifica-

340 See supra note 89 and accompanying text.

341 The use of performance requirements in the motor vehicle sector is not uncommon, although many of these measures are being repealed or phased out. See WTO Council for Trade in Goods, Trade-Related Investment Measures and Other Performance Requirements, Joint Study by the World Trade Organization and UNCTAD Secretariats, Addendum 2-6, G/C/W/307/Add.1 (Feb. 8, 2002) (describing performance requirements used in various countries' motor vehicle industries). 
tion, approval, or authorization requirements that are sometimes contingent upon satisfying criteria that are highly subjective and, therefore, subject to political manipulation); measures relating to ownership and control (e.g., limitations on the nationality or residency of senior managers or members of the board of directors, local equity requirements, and restrictions on the acquisition of real estate); and measures relating to operations (e.g., currency exchange controls and employment requirements). ${ }^{342}$ As a group, these measures are negative TRIMs. While the TRIMs Agreement prohibits performance requirements tied to the purchase of local versus foreign-source goods, as well as measures that tie the amount of foreign exchange and imported inputs to the value of exports, many other performance requirements, such as technology transfer requirements, mandatory use of local business partners, or foreign exchange controls that prevent the free repatriation of profits, are not the subject of the TRIMs Agreement. Such performance requirements are likely to deter, not attract, FDI and its associated technology, perhaps preventing increased competition in local markets. ${ }^{343}$ However, given the competitive environment for FDI,

342 For a list of examples of investment measures relating to admission and establishment, ownership and control, and operations, see WORLD INVESTMENT REPORT 1996, supra note 10, at 176-79 (discussing investment measures affecting the entry and operations of foreign investors). In the results of a survey released in 2000, the Canadian Chamber of Commerce and Industry Canada reported an inventory of more than 110 specific restrictions on investment. See Canadian Chamber of Commerce, supra note 14 . The Report summarized that $38 \%$ of the barriers resulted in the investment being canceled, $43 \%$ resulted in the terms of the investment being altered, and $25 \%$ of the restrictions involved discretionary decision-making on the part of the host government. The Report is summarized in a submission by Canada to the WGTI. See WTO Working Group on the Relationship Between Trade and Investment, Communication from Canada, WT/WGTI/W/97 (Mar. 9, 2001) (presenting results obtained in a report on foreign investment barriers).

${ }_{343}$ As noted in a U.S. submission to the WTO Working Group on Trade and Investment:

Sometimes these investment screening regimes have even been given a competition policy rationale, one based on concern that efficient new market entrants could harm existing local competitors and perhaps achieve a local monopoly. In our view, these concerns are largely misplaced, especially if foreign entry is by way of "greenfield" investment rather than through acquisition of a local competitor. On the conceptual level, competition policies that attempt to protect (established) competitors, rather than consumers, are inherently suspect; after all, competition laws should protect competition, not competitors. While other rationales are sometimes asserted for maintaining such protective policies, competition rarely is enhanced by them. 
it can be anticipated that countries motivated to attract FDI will eliminate these disincentives to foreign investment out of pure selfinterest. If that doesn't occur, foreign capital will probably have little difficulty in finding an alternative host country where such disincentives do not exist. At the same time, negative TRIMs may be negotiable, so even if in theory they would have an impact on FDI flows, an investor may be able to negotiate around them. One study found that in $83 \%$ of the projects covered by negative TRIMs, investors claimed that the TRIM merely made them do what they would have done in any event. ${ }^{344}$ That same study found that $63 \%$ of respondents were compensated for the imposition of the TRIM.345

With regard to possible improvements of the TRIMs Agreement to make it less distortive of FDI flows, consideration should be given to amending the TRIMs Agreement by incorporating the NAFTA provisions on negative TRIMs, especially those dealing with technology transfer and membership on corporate boards. ${ }^{346}$ The list of proscribed practices in NAFTA Article 1106 includes export performance requirements, domestic content requirements, trade balancing, product mandating (i.e., giving a preference to local sources of supply), and technology transfer requirements. ${ }^{347}$ Under Article 1106, a NAFTA party may not, as a condition for the establishment or operation of an investment, impose any of the following seven restrictions on a firm: ${ }^{348}$

- limit its sales in the domestic market by conditioning such sales on exports or foreign exchange earnings;

- buy or use components from a local supplier or accord a preference to domestic goods or services;

- achieve a minimum level of "domestic content";

WTO Working Group on the Relationship Between Trade and Investment, Communication from the United States 5, WT/WGTI/W/55 (Sept. 25, 1998).

344 See EVANS \& WALSH, supra note 66, at 33.

345 See id.

346 See WTO Working Group on the Relationship Between Trade and Investment, Communication from the Separate Customs Territory of Taiwan, Penghu, Kinmen and Matsu, Development Provisions, at 2, WT/WGTI/W/126 (July 1, 2002) (noting that requiring foreign investors to transfer technology to domestic firms or to the government might have the counterproductive effect of deterring FDI).

347 The NAFTA proscription on technology transfer is not included in the Illustrative List of the TRIMs Agreement. See TRIMs Agreement, supra note 235, Annex, at 1452.

348 See NAFTA art. 1106.1, supra note 26, at 1101-02 (listing seven performance requirements no party may enforce). 
- limit its imports to a certain percentage of exports or foreign exchange inflows associated with the investment;

- transfer technology to any domestic entity, except to remedy an alleged violation of competition [i.e., antitrust] law;

- export a specified level of goods or services; or

- supply designated regional or world markets solely from its local production.

The obligation to refrain from such practices extends to the investments by investors of both a NAFTA party and by non-parties alike. ${ }^{349}$ NAFTA Chapter Eleven also forbids the NAFTA parties from requiring that senior managers be of any particular nationality. However, the NAFTA parties may require that the majority of the members of a board of directors be of a specific nationality, provided that such a requirement does not materially impair the ability of the investor to exercise control over its investment. 350

Turning to the issue of investment incentives, as a preliminary matter investment incentives come in several forms: (1) financial incentives (funds paid directly to the investor in the form of grants and subsidized loans); (2) fiscal incentives (tax holidays or exemptions from import duties on capital goods); and (3) indirect incentives, such as subsidized services or market privileges (e.g., the provision of infrastructure at less-than-market prices, preferential treatment in obtaining government procurement contracts, or a monopoly position in the market). ${ }^{351}$ Regarding the issue of in-

349 See id. (extending the reach of the article to investors of a party or of a non-party in its territory).

350 See id. art. 1107 , supra note 26 , at 1103 . Query whether developing countries would have any interest in expanding the TRIMs Agreement to cover more negative TRIMs, in the absence of some type of compensatory adjustment in the areas of, for example, the use of antidumping duties by developed countries or greater market access for goods of export interest to developing countries, such as textiles, clothing, and agricultural products. See Sauve \& Wilkie, supra note 16, at 14 (discussing investment policy issues at the WTO).

351 See Trade and Foreign Direct Investment, supra note 11, at 21-24 (classifying investment incentives into three categories). For a list of the main types of investment incentives, see WORLD INVESTMENT REPORT 1996, supra note 10, at 180. For an inventory of common incentives, see WTO Working Group on the Relationship Between Trade and Investment, Note by the Secretariat, The Impact of Investment Incentives and Performance Requirements on International Trade, at 6, WT/WGTI/W/56 (Sept. 30, 1998). 
vestment incentives, ${ }^{352}$ arguments have been advanced that investment incentives distort FDI inflows, but here the evidence of such distortions is not clear. ${ }^{353}$ Just as the prohibition on the use of export subsidies and import-substitution subsidies on other than agricultural products was agreed to in the Agreement on Subsidies and Countervailing Measures ("SCM Agreement"), it is argued that the same disciplines need to be imposed on the use of investment incentives and for the same reason: The use of such incentives has the potential for distorting the market for capital, just as the use of export and import substitution subsidies distort global patterns for trade in goods. ${ }^{354}$ Investment incentives may have more of an impact on FDI flows than negative TRIMs (although the precise impact of incentives on FDI and trade flows remains the subject of conjecture). .355

The counter-argument has been made that if governments compete for FDI through investment incentives, this helps insure that FDI goes to those places where it is most highly valued. ${ }^{356}$

352 Despite NAFTA's restrictions on performance requirements, the NAFTA parties remain free to use positive TRIMs that condition the receipt of government subsidies (e.g., a tax holiday in exchange for building a facility in an economicallydepressed region of the country) on where facilities are located, on training or employing workers, on the construction or expansion of particular facilities, or on conducting research and development. See NAFTA art. 1106.4, reprinted in NAFTA STATEMENT OF ADMINISTRATIVE ACTION, supra note 26, at 1102. Saggi:

353 See Hoekman \& Saggi, supra note 8, at 12. As observed by Hoekman and

[T] $T$ he empirical evidence regarding the efficacy of financial incentives to attract FDI is ambiguous.... If one accepts the notion that there is a solid economic case for promoting inward FDI via incentives because of positive externalities [generated by MNEs], countries may find themselves in a bidding war for attracting FDI.... If this is an important possibility, there is a potential case for international cooperation to ban or discipline the use of fiscal incentives.

Id. at 11 .

354 See Patrick Low \& Arvind Subramanian, TRIMs in the Uruguay Round: An Unfinished Business?, in THE URUGUAY ROUND AND THE DEVELOPING ECONOMIES 413, 414 (Will Martin \& L. Alan Winters eds., 1995) (arguing that as with subsidies in trade in goods, investment incentives tend to distort the allocation of FDI).

355 See WTO Working Group on the Relationship Between Trade and Investment, Communication from ASEAN 1, WT/WGTI/W/41 (July 3, 1998) (addressing recent debate regarding the efficiency of investment incentives).

356 "Subsidy freedom" has been advocated in cases where incentives are effective in attracting FDI. See Eric W. Bond \& Larry Samuelson, Tax Holidays as Signals, 76 AMER. ECON. REV. 820-26 (1986) (examining the potential role of tax holidays as a signal). 
Moreover, the advocates of an SCM Agreement approach forget how difficult it was to conclude that Agreement, given the importance of subsidies to governments' development policies. The significant carve-out of agricultural subsidies from industrial subsidies must also not be forgotten, the former being covered in the WTO Agreement on Agriculture and with far fewer disciplines than is the case under the SCM Agreement.

Developing countries are at a clear disadvantage vis-à-vis developed countries in any investment incentive competition where an incentives package is determinative in the investment location decision. The spread of investment incentives can distort investment patterns in favor of developed countries that have deeper pockets. This assumes, of course, that developing countries and developed countries are in fact in competition for the same FDI. It seems more likely that developing countries compete inter se for FDI. 357

In defense of incentives it has been suggested that they draw foreign investment where they help correct market failures, e.g., weak infrastructure, such as roads and telecommunication networks. When used for this reason, incentives can be considered a country risk premium, providing a partial counterweight to the lack of adequate infrastructure. ${ }^{358}$ Investment incentives also have

\section{UNCTAD adds that:}

Experience suggests that incentives do not rank high among the determinants of FDI, although their impact on FDI locational choices is sometimes apparent at the margin.... In many instances, therefore, incentives can be a waste of resources-something most countries can illafford - and, when they are successful, can be distortional.

WORLD INVESTMENT REPORT 1996, supra note 10, at 181 . For example, if a country offers $\$ 200$ million in incentives to attract a FDI project that brings $\$ 150$ million in total benefits, the host country is net $\$ 50$ million worse off with the FDI than without it. On the other hand, judicious use of incentives as part of a carefully thought-out macroeconomic strategy could have wealth-creation effects that more than offset the costs associated with providing the incentives.

358 See WTO Working Group on the Relationship Between Trade and Investment, Communication from Singapore, WT/WGTI/W/99, at 2-3 (Mar. 13, 2001); WTO Working Group on the Relationship Between Trade and Investment, Communication from Korea 1, WT/WGTI/W/62 (Oct. 28, 1998); WTO Working Group on the Relationship Between Trade and Investment, Communication from ASEAN 2, WT/WGTI/W/41 July 3,1998) (addressing the risk premium function as a key role of incentives). But see WTO Working Group on the Relationship Between Trade and Investment, Note by the Secretariat, The Impact of Investment Incentives and Performance Requirements on International Trade 7, WT/WGTI/W/56 (Sept. 30, 1998) ('If investors request a 'risk premium' to compensate for the risk associated with macroeconomic instability, runaway inflation and exchange rate fluctua- 
been defended on the ground that they serve as a directional tool or carrot to regulate the type and nature of FDI a country receives. ${ }^{359}$ For example, incentives that are granted sequentially can protect against unscrupulous investors who promise to modernize, diversify, or add production capacity but who later renege on their commitment. ${ }^{360}$ Finally, investment incentives have been defended on the ground that they attract the kind of investment that leads to long-term competitiveness because along with capital comes technology transfer, managerial know-how, and ready-made access to overseas markets. 361

Although all host countries might mutually benefit if they voluntarily foreswore the use of investment incentives, individual "cheaters" would gain from continuing to offer incentives regardless of what other countries do. Because of this "prisoners' dilemma," as economists call it, host countries harm themselves by pursuing their narrow self-interests and providing incentives. When all countries offer incentives, the incentives may simply cancel each other out, and investments will essentially be made in the same way as if no country was offering incentives in the first place. As the WTO Secretariat has explained:

tions, the most sensible policy response would be to address these underlying problems ... rather than to compensate investors for the poor investment climate."); WTO Working Group on the Relationship Between Trade and Investment, Communication from Mexico 3, WT/WGTI/W/64 (Nov. 19, 1998) ("To attract FDI it is preferable to remedy, and not to compensate for, structural or economic imperfections [through fiscal incentives]."); Pham Van Thuyet, Vietnam's Legal Framework for Foreign Investment, 33 INT'L LAW. 75, 77 (1999) ("[W]hat investors need most is reasonably good infrastructure .... Tax incentives alone are not sufficient to lure investors....").

359 See WTO Working Group on the Relationship Between Trade and Investment, Communication from ASEAN 2, WT/WGTI/W/41 (July 3, 1998) (discussing the role of incentives as a directional tool); WTO Working Group on the Relationship Between Trade and Investment, Communication from Singapore 2-3, WT/WGTI/W/99 (Mar. 13, 2001) (addressing incentives as a directional tool); WTO Working Group on the Relationship Between Trade and Investment, Communication from Korea 1, WT/WGTI/W/62 (Oct. 28, 1998) (discussing incentives provided to FDI that accompany technology).

360 See WTO Working Group on the Relationship Between Trade and Investment, Communication from ASEAN 3, WT/WGTI/W/41 (July 3, 1998) (stating that "[i]ncentives may help curtail 'fly-by-night' investors.").

${ }^{361}$ See id. But see WTO Working Group on the Relationship Between Trade and Investment, Communication from Korea 8, WT/WGTI/W/62 (Oct. 28, 1998) (noting that tax incentives have generally failed to achieve their desired effects). 
$[\mathrm{H}]$ ost country pursuit of the perceived first best solution attracting investment from other countries-destroys the possibility of achieving a second best solution in which no country offers incentives, and countries therefore end up in a third best solution with incentives being paid out, but with few, if any, effects on investment allocation. ${ }^{362}$

An amended TRIMs Agreement that imposes disciplines and limitations on the use of investment incentives would permit WTO members to break out of the "prisoners' dilemma," which could be especially important for developing countries that cannot expect to outspend developed countries in any investment incentive competition. ${ }^{363}$ The question is whether such an amendment would

362 Trade and Foreign Direct Investment, supra note 11, at 21 n.83. Accord WTO Working Group on the Relationship Between Trade and Investment, Communication from Korea 3, WT/WGTI/W/62 (Oct. 28, 1998) (arguing that incentives could unnecessarily increase the cost to society of producing goods and services). But see Hoekman \& Saggi, supra note 8, at 12 ("[I]f financial incentives are ineffective [in attracting FDI], there is no rationale for seeking multilateral disciplines prohibiting fiscal incentives as it is in each countries [sic] self-interest not to offer them.").

363 The question has been raised why it is that developed countrieschampions in word, if not in deed, of market mechanisms-also use investment incentives if they are in fact as distortive of the market for capital as has been argued. See WTO Working Group on the Relationship Between Trade and Investment, Report (1999) of the Working Group on the Relationship Between Trade and Investment to the General Council 10, WT/WGTI/3 (Oct. 22, 1999) (asking why developed countries used incentives when they "took the view that market forces should determine the allocation of resources"). In the Uruguay Round the EU opposed restrictions on investment incentives, arguing that they are part of domestic industrial policy and, therefore, could not be covered in a WTO agreement without infringing upon national sovereignty. See EVANS \& WALSH, supra note 66, at 34. Modest attempts to corral investment incentives have been taken in the OECD Decision on Incentives and Disincentives (part of the 1976 OECD Declaration on Multinational Enterprises), in the Caribbean Common Market agreement on the harmonization of fiscal incentives, and in the EU as part of its competition rules. See WORLD INVESTMENT REPORT 1996, supra note 10, at 181. The non-binding OECD Decision on International Investment Incentives and Disincentives stresses the need to strengthen international cooperation in this area by urging member countries to give due weight to the interests of other member countries affected by investment incentives or disincentives. The Decision encourages countries to make investment incentive measures as transparent as possible so that their scale and purpose can be easily determined. The Decision was revised in 1984 and again in 1991 to provide for consultations and review procedures to make cooperation between adhering countries more effective. See OECD, Decision on International Investment Incentives and Disincentives, Second Revised Decision of the Council, DAFFE/IME(2000)02 (May 1984). The impact of these regional and plurilateral efforts have been limited. See WORLD INVESTMENT REPORT 1996, supra 
achieve the desired result. In the case where two developing countries would have competed against each other by offering location incentives, an agreement to refrain from the use of investment incentives would be in effect a collusive agreement among developing countries. Of course, only one country can be the recipient of the FDI, but the hope must be that in the long run everything evens out. Yet no lawyer or economist can make such a promise and deliver on it. ${ }^{364}$

Despite the arguments against using investment incentives, "[a]rguments on the pros and cons of investment incentives have never been conclusive and are unlikely ever to be so." 365 Many developing countries still dangle new ones to attract FDI. ${ }^{366}$ For them, investment incentives remain an important policy instrument in the pursuit of development strategies. 367 Moreover, because developing countries are net importers of FDI, they have no reason to negotiate an agreement that focuses on investment incentives unless the negotiations are expanded to include other issues of interest to them. 368

Certain investment incentive programs will present knotty issues for negotiation. For example, the draft MAI specified that government subsidies or advantages offered for training or employing certain workers or for constructing and expanding facilities would not have been barred. ${ }^{369}$ Whether legislation that gives

note 10 , at 181 (observing that "incentives do not rank high among the determinants of FDI").

364 See Markusen, supra note 8 , at 53 (attempting to create a model with fixed and open policies and procedures for regulating investment).

365 WTO Working Group on the Relationship Between Trade and Investment, Communication from Singapore 3, WT/WGTI/W/99 (Mar. 13, 2001). See also Hoekman \& Saggi, supra note 8, at 2 (concluding that regardless of whether investment incentives work or not, "there is no clear case for international cooperation that restricts the ability of governments to pursue national policies").

366 See, e.g., Philippines Passes Law Giving Breaks to Attract Investment by Multinationals, 16 Int'1 Trade Rep. (BNA) 2043 (Dec. 16, 1999) (describing how multinational firms setting regional headquarters in the Philippines are not subject to income tax or value-added tax); Glen Perkinson, Indonesia Preparing Tax Breaks to Attract More Foreign Investors, 16 Int'1 Trade Rep. (BNA) 1400 (Aug. 25, 1999) (describing Indonesian tax incentives).

367 See WTO Working Group on the Relationship Between Trade and Investment, Report (1998) of the Working Group on the Relationship Between Trade and Investment to the General Council 22, WT/WGTI/2 (Dec. 8, 1998).

368 See Hoekman \& Saggi, supra note 8 , at 2 (observing that no clear case for international cooperation in restricting incentives exists).

369 See MAI NeGOTIATING TEXT, supra note 28 , at 22 n.29. 
special preferences for socially or economically disadvantaged minority groups, e.g., preferences to minority-owned small businesses in bidding on government contracts, should be excluded from or included on the list of prohibited investment incentives presents another thorny issue. On the other hand, prohibiting incentives would have the salutary benefit of preventing disputes over MFN treatment. For example, what if an investor from Country A was offered certain incentives for making an investment in Country C, but an investor with the same kind of investment from Country B was not made the same offer? The discretionary administration of incentive programs, which can be an important element in a country's development plans, might have to be eliminated or severely curtailed if MFN treatment issues are to be avoided. Against this backdrop of strong differences of opinion over the value of investment incentives, perhaps the appropriate response is to strengthen the capacity of governments to effectively administer incentive programs rather than prohibit their use. ${ }^{370}$ Considering the near impossibility of controlling local tax regimes through a multilateral agreement on investment, any prohibitions on investment incentives could be circumvented.

In sum, given the diversity of opinion on the pros and cons of investment incentives, negotiations on disciplining the use of investment incentives should be postponed indefinitely. ${ }^{371}$

\subsection{Is the Current Legal Regime for FDI Unstable and Unpredictable?}

One of the most frequently touted benefits of a multilateral agreement on investment is that it would introduce predictability and stability to a presumably unpredictable and unstable world regarding FDI. 372 Unfortunately, this view either ignores or under-

370 It has been suggested that the SCM Agreement, which distinguishes between prohibited and permitted subsidies, be used as a model for classifying and regulating investment incentives. See WTO Working Group on the Relationship Between Trade and Investment, Report (1999) of the Working Group on the Relationship Between Trade and Investment to the General Council 11, WT/WGTI/3 (Oct. 22, 1999) (discussing the dispute over the definitions used in the SCM Agreement).

371 In the words of the WTO Secretariat, "As competition for FDI intensifies, potential host governments find it increasingly difficult to offer less favourable conditions for foreign investment than those offered by competing nations." Trade and Foreign Direct Investment, supra note 11, at 21. But see Sauvé \& Wilkie, supra note 16, at 14 (citing authors who acknowledge the complexity of the issue and the reluctance of key players to address it).

372 See, e.g. Drábek, supra note 6, at 4-5 (noting foreign investors' need for transparent and predictable rules). 
estimates the role played by the network of bilateral and regional agreements on foreign direct investment. The part played by BITs and regional agreements on investment in quickening the pace of FDI flows, not to mention autonomous measures taken at the national level to improve the climate for foreign investment, should not be overlooked or minimized. The huge number of parallel legal regimes at the bilateral and regional level, as well as national laws designed to encourage inflows of foreign capital, evidence the perception, if not the reality, that BITs and regional investment agreements facilitate the cross-border movement of foreign capital.373 UNCTAD reports that the network of bilateral investment treaties has quintupled during the 1990s, reaching 1941 by the end of 2000 , compared to some 400 at the beginning of $1990 . .^{374}$ "The

373 See UNCTAD, INTERNATIONAL INVESTMENT INSTRUMENTS: A COMPENDIUM, vols. I-III (1996), vols. IV-V (2000), vol. VI (2001), vols. VII-IX (2002) (collecting bilateral and regional instruments on foreign direct investment); WTO Working Group on the Relationship Between Trade and Investment, Bilateral, Regional, Plurilateral and Multilateral Agreements, Note by the Secretariat, WT/WGTI/W/22 (Jan. 26, 1998); UNCTAD, TRENDS IN INTERNATIONAL INVESTMENT AGREEMENTS: AN OVERVIEW 94-103 (1999) [hereinafter TRENDS IN INTERNATIONAL INVESTMENT AGREEMENTS] (listing 105 of the main bilateral, regional, and multilateral instruments dealing with FDI from 1948 to 1999); ORGANIZATION OF AMERICAN STATES, INVESTMENT AGREEMENTS IN THE WESTERN HEMISPHERE: A COMPENDIUM (1999) (noting that sweeping economic reforms have led to a substantial liberalization in the investment regimes of most countries in the hemisphere); Trade and Foreign Direct Investment, supra note 9, at 27-28 (listing sixteen regional investment agreements).

374 UNCTAD, WORLD INVESTMENT REPORT 2001: PROMOTING LINKAGES 6 (2001) [hereinafter WORLD INVESTMENT REPORT 2001]. UNCTAD notes that as of 1999, out of some $1700 \mathrm{BITs}$, less than $10 \%$ involve OECD countries; that is, most BITs are concluded between a developed country and a developing country or between two developing countries. See LESSONS FROM THE MAI, supra note 21, at 22 n.8. One BIT was concluded on average every 2.5 days in 1997. See WORLD INVESTMENT REPORT 1998, supra note 10, at xix. The number of double taxation treaties also increased, numbering 1982 at the end of 1999. See WORLD INVESTMENT REPORT 2000, supra note 273, at xv. As of August 2002, the United States had concluded forty-five BITs with the following countries (unless otherwise indicated by an asterisk, the year indicates when the BIT entered into force; an asterisk indicates the year the BIT was signed): Albania (1998); Argentina (1994); Armenia (1996); Azerbaijan (1997*); Bahrain (1999); Bangladesh (1989); Belarus (1994*); Bolivia (1998*); Bulgaria (1994); Cameroon (1989); Democratic Republic of the Congo (1989); Republic of the Congo (1994); Croatia (1996*); Czech Republic (1992); Ecuador (1997); Egypt (1992); El Salvador (1999*); Estonia (1997); Georgia (1997); Grenada (1989); Haiti (1983*); Honduras (1995*); Jamaica (1997); Jordan (1997*); Kazakhstan (1994); Kyrgyzstan (1994); Latvia (1996); Lithuania (1998*); Moldova (1994); Mongolia (1997); Morocco (1991); Mozambique (1998*); Nicaragua (1995*); Panama (1991); Poland (1994); Romania (1994); Russia (1992*); Senegal (1990); Slovakia (1992); Sri Lanka (1993); Trinidad \& Tobago (1996); Tunisia (1993); Turkey 
common thread that runs through the proliferation of both types of treaties," UNCTAD concludes, "is that they reflect the growing role of FDI in the world economy and the desire of countries to facilitate it." 375 As of January 1, 2000, the forty-nine LDCs had con-

(1990); Ukraine (1996); and Uzbekistan (1994*). A current list of U.S. BITs and a sample BIT are available at $\mathrm{http} / /$ www.state.gov/www/issues/economic /7treaty.html. The forty-five countries with which the United States has concluded BITs account for approximately $5 \%$ of total U.S. FDI. See U.S. INT'L TRADE COMM'N, THE YEAR IN TRADE 1994: OPERATION OF THE TRADE AGREEMENTS PROGRAM 68 (1995).

375 WORLD INVESTMENT REPORT 1998, supra note 10, at xix. A sample of regional activities focused on investment are the Free Trade Area of the Americas (FTAA) negotiations, U.S. outreach to Latin America, APEC initiatives, and the ASEAN Free Trade Area.

At the Second Summit of the Americas held in Santiago, Chile, in April 1998, the thirty-four heads of state participating in the FTAA negotiations accepted the recommendations made by their trade ministers in San Jose and officially launched negotiations on a Free Trade Area of the Americas. See Second Summit of the Americas, Santiago Declaration, Apr. 19, 1998, available at http://www.sice.oas.org/ftaa/santiago/sadop_e.htm. The heads of state also issued a Plan of Action, a body of concrete initiatives intended to promote the overall development of FTAA countries. See Second Summit of the Americas, Plan of Action, Apr. 19, 1998, available at http://www.sice.oas.org/ftaa/santiago /sapoa_e1.stm. The Santiago Declaration reiterates the negotiators' commitment to complete FTAA negotiations by 2005. The Declaration also states that the FTAA will be balanced, comprehensive, WTO-consistent, and will constitute a single undertaking (i.e., it will be an all-or-nothing, package deal). An agreement on investment is among the list of agenda items.

On October 30, 1998, the United States and the five-member Andean Pact or Community (Bolivia, Colombia, Ecuador, Peru, and Venezuela) signed an agreement establishing a U.S.-Andean Community Trade and Investment Council. The Council will address key trade and investments issues, including the FTAA negotiations, protection of intellectual property rights, and trade issues under the Andean Trade Preference Act.

On October 8, 1998, ASEAN finance ministers agreed to adopt a framework agreement on an ASEAN Investment Area. Under the Investment Area, ASEAN investors are to receive national treatment by 2010 (2013 for Vietnam and 2015 for Laos and Burma), which will be extended to all investors by 2020 . Each ASEAN member is to submit a list of excepted industries by mid-1999. See Jason Gutierrez, ASEAN Finance Ministers Approve Investment Pact, 'Surveillance' Mechanism, 15 Int'l Trade Rep. (BNA) 1716 (Oct. 14, 1998). In September 2001, the ASEAN members agreed to move up the deadlines for eliminating certain exceptions in the framework investment agreement from 2020 to 2010. See Rafael D. Frankel, Deadlines for ASEAN Investment Area Moved Up in Bid to Draw Foreign Investment, 18 Int'1 Trade Rep. (BNA) 1476 (Sept. 20, 2001).

The twenty-one-member Asia-Pacific Economic Cooperation forum has three permanent Committees. In 1993, a Committee on Trade and Investment was created to assume the duties of the working group assigned to that task. The work program of the Committee includes reviewing the results of the Uruguay Round and its implications for the region, pursuing efforts to simplify and harmonize 
cluded a total of 224 BITs, about half (120) with developed countries. ${ }^{376}$

As noted by India in a submission to the WGTI, bilateral investment treaties "provide a predictable climate for foreign investments." ${ }^{377}$ At the same time, even in the absence of a BIT, FDI may still flow into a host country, drawing into question the relevance on a WTO agreement on investment. ${ }^{378}$ Because the decision to make an FDI is multifaceted, there may be no reason to believe that multilateral investment rules would lead to increased FDI flows. ${ }^{379}$ In short, neither the presence of a multilateral agreement on investment nor the absence of a BIT may be a determining factor in FDI inflows.

customs procedures in the region, and examining the investment environment within APEC. See Joint Statement of APEC Ministers, Declaration on an APEC Trade and Investment Framework, Annex 1 (Nov. 20, 1993). The APEC NonBinding Investment Principles were adopted in 1994. They deal, inter alia, with transparency, non-discrimination among investor nations, national treatment, investment incentives, performance requirements, expropriation and compensation, repatriation and convertibility, dispute settlement, temporary entry of personnel, and avoidance of double taxation. The Investment Principles also encourage members to minimize the use of performance requirements that distort or limit the expansion of trade and investment. See WTO Working Group on the Relationship Between Trade and Investment, Communication from APEC, WT/WGTI/W/9 (Oct. 6, 1997) (outlining APEC's approach to investment); Trade and Foreign Direct Investment, supra note 11, at 30-31; WORLD INVESTMENT REPORT 1996, supra note 10, at 140-42. The APEC Investment Principles are available at http://www.apecsec.org.sg.

376 FDI IN LEAST DEVELOPED COUNTRIES, supra note 286, at 14 (noting 120 BITs conducted between LDCs and developed countries).

377 WTO Working Group on the Relationship Between Trade and Investment, Communication from India 3, WT/WGTI/W/74 (Apr. 13, 1999). India added that "studies have also pointed out that transnational corporations may not even be aware of the existence of such treaties - the determinants of their FDI decision lie elsewhere." Id. See also WTO Working Group on the Relationship Between Trade and Investment, Communication from India 3, WT/WGTI/W/72 (Apr. 13, 1999) ("[E]ven bilateral investment agreements have little effect on FDI flows.").

378 For example, in the absence of a BIT between Chile and Peru, Chilean investors still invested $\$ 1$ billion in Peru between 1993 and 1996 . Likewise, in the absence of a BIT between the United States and Peru, the total stock of U.S. investment in Peru in 1997 was $\$ 1.46$ billion. See WTO Working Group on the Relationship Between Trade and Investment, Communication from Peru, Bilateral Treaties for the Promotion and Reciprocal Protection of Investment: The Case of Peru 3, WT/WGTI/W/47 (July 8, 1998).

379 See WTO Working Group on the Relationship Between Trade and Investment, Report (2001) of the Working Group on the Relationship Between Trade and Investment to the General Council 3-4, WT/WGTI/5/Rev.1 (Oct. 22, 2001). 
While the arguments put forward by the advocates of a multilateral investment agreement could easily leave one with the impression that national barriers to foreign capital are high, deep, and wide, and that the international legal environment for capital is unstable and unpredictable, the fact is that since the 1980s the worldwide trend in national legislation regulating FDI has been to adopt laws that attract foreign investors by creating a favorable investment climate. ${ }^{380}$ UNCTAD reports that "[i]n recent years, there has been a sea-change in the attitudes of developing country governments towards FDI and [transnational corporation] activities." 381 Out of 599 changes in FDI legal regimes between 1991 and 1996, 95\% went in the direction of more liberal investment rules. 382 UNCTAD found that in 1997 at least 151 changes in FDI regulatory regimes were made by seventy-six countries, $89 \%$ of which were in the direction of creating a more favorable environment for FDI. ${ }^{383}$ In 1998 the trend was the same: of 145 regulatory changes relating to FDI by sixty countries, $94 \%$ were in the direction of creating a more favorable climate for FDI. 384 Similarly, in 2000 there were 150 regulatory changes affecting FDI, of which 147 were more favorable to FDI. ${ }^{385}$ UNCTAD also reports that at the national level most of the forty-nine LDCs have legislation in place that liberalizes restrictions on FDI, provides for national treatment of FDI, allows profit repatriation, and protects against expropriation..$^{386}$

380 See TRENDS IN INTERNATIONAL INVESTMENT AGREEMENTS, supra note 373, at 30 (indicating that the overwhelming majority of national regulatory changes affecting FDI that have been introduced between 1991 and 1998 have been favorable to FDI); FREE TRADE OF THE AMERICAS WORKING GROUP ON INVESTMENT, FOREIGN INVESTMENT REGIMES IN THE AMERICAS: A COMPARATIVE STUDY (1999) (noting the favorable legal climate for foreign investment within the hemisphere). For a list of 143 countries that have enacted special FDI legal regimes at the national level, see WORLD INVESTMENT REPORT 1998, supra note 10, at 56 tbl. III.1.

381 Working Group on the Relationship Between Trade and Investment, Note by the UNCTAD Secretariat, Transnational Corporations, Foreign Direct Investment and Development 5, WT/WGTI/W/8/Add.1 (Sept. 26, 1997).

382 Id.

383 WORLD INVESTMENT REPORT 1998, supra note 10, at xix.

384 WORLD INVESTMENT REPORT 1999, supra note 284, at xviii.

385 WORLD INVESTMENT REPORT 2001, supra note 374, at 6.

386 See FDI IN LEAST DEVELOPED COUNTRIES, supra note 286, at 13. UNCTAD adds that an important area of reform involves limiting requirements on local equity participation, thereby expanding the amount of foreign ownership and control of an investment. Id. 
Finally, regarding the alleged transaction costs that are imposed upon MNEs in becoming familiar with a multitude of BITs and national investment laws, Hoekman and Saggi observe:

[I]t seems that the major proportion of the transactions [sic] costs associated with FDI is likely to arise from differences in language, culture, politics, and the general business climate of a host country. Familiarizing oneself with the investment laws of a country seems trivial in contrast to those more daunting challenges that exist regardless of whether the country is a signatory to a multilateral or a bilateral investment agreement. ${ }^{387}$

In short, in order to answer in the affirmative the question whether a globalization response to regulating FDI is preferable to the internalization response, a stronger case for globalization needs to be made.

\section{A WTO AGREEMENT ON INVESTMENT: BUILDING A CONSENSUS}

Why should WTO members negotiate an agreement on investment, besides the fact that powerful WTO members, most notably the EU, favor such an agreement? Assuming that the economically weaker WTO members do not submit to the will of the stronger members, several conditions must be met before negotiating and successfully concluding a multilateral FDI agreement under WTO auspices.

A first condition is a consensus among policy-makers and governments as to the value of having an open investment climate. Moving the key players to the point where they perceive it to be in their national interest to have international rules on investment is the critical first step. Despite different political and economic philosophies among WTO members as to the proper role of government in the national economy and in controlling the flow of foreign capital, a consensus is building in favor of FDI generally. Still, many countries-especially, but not exclusively, developing countries - constantly wrestle with the question of whether the energy, telecommunications, transportation, and natural resources sectors should be government-owned, privatized but owned solely by na-

387 Hoekman \& Saggi, supra note 8, at 16-17. 
tionals, or privatized and open to foreign ownership. Issues of national sovereignty, in both developed and developing countries, cannot be underestimated. Developing countries ask what advantages flow from a multilateral agreement on investment when their development objectives are best achieved through autonomous liberalization in conjunction with BITs. A multilateral agreement on investment would only tie the hands of developing countries with regard to performance requirements, such as technology transfer, and the use of investment incentives. ${ }^{388}$

Closely related to the national sovereignty hurdle blocking a multilateral investment agreement are powerful, and too often underestimated, sentiments of nationalism and national pride that prevent a consensus from building on a multilateral investment agreement. This sentiment runs especially strong when the topic is protecting cultural industries from being overwhelmed or acquired by foreign investors. These deep feelings of national pride threaten any multilateral investment agreement.

WTO members have to believe that it is in their economic selfinterest to conclude a multilateral agreement on investment. Such a consensus unquestionably developed in the case of international trade in goods and services, as evidenced by the broad-based membership in the WTO. But even then many countries' commitment to the goal of free trade has been less than unflagging over the past fifty-five years, and the consensus, as shaky as it is, took more than 200 years to build from the time Adam Smith first wrote on the economic benefits of liberal trade.

A second condition is a consensus on the best forum for negotiating multilateral rules on investment. Many good arguments can be made for placing such negotiations in the WTO. The WTO could very well prove to be a hospitable forum for negotiating an FDI agreement, as suggested by some scholars, 389 because of the opportunities for using bargaining chips and making trade-offs among and between trade sectors. The WTO counts among its 145 members all the world's developed countries and the major developing countries, including Brazil, India, and China. Considering

388 See WTO Working Group on the Relationship Between Trade and Investment, Report (2000) of the Working Group on the Relationship Between Trade and Investment to the General Council 10, WT/WGTI/4 (Nov. 27, 2000).

389 See, e.g., Ernest-Ulrich Petersmann, International Competition Rules for Govermments and for Private Business: A "Trade Law Approach" for Linking Trade and Competition Rules in the WTO, 72 CHI.-KENT L. REV. 545, at 560-61 (1996). 
the diverse and broad WTO membership that includes developed, developing, and emerging economies, a strong argument can be made that the WTO is the proper forum for concluding a multilateral investment agreement, not only because of its broad-based membership, but because of the close link between trade and liberalized investment rules. 390

Historically, the WTO's predecessor, the GATT, had as its raison d'être for the elimination of government barriers to international trade in goods. With the establishment of the WTO in 1995, that portfolio has been expanded to cover trade in services and the protection of intellectual property. In fulfilling its primary mandate, that is, completing the unfinished business of eliminating the many government-supported barriers to market access to foreign goods and services, it might be appropriate to add to the Organization's portfolio an agreement to eliminate government barriers to FDI. However, negotiating rules on investment is far outside the WTO's portfolio of trade in goods and services. The liberalization of capital flows touches upon far more sensitive issues than does liberalization of markets for goods and services. If the OECD negotiations on the stillborn MAI are any clue, WTO negotiations on an investment agreement would be so politically charged that they would undoubtedly become a lightening rod to which wellorganized environmental and labor NGOs would be attracted. Ignoring civil society and still reaching an agreement proved impossible in the MAI negotiations. This suggests that perhaps NGOs should somehow be co-opted by including them in the negotiations in order to lend legitimacy to them. ${ }^{391}$ Though perhaps sound as a theoretical matter, as a practical matter, such a strategy seems doomed from the start.

Looking down the road, should the WTO members successfully conclude an agreement on investment, query whether the WTO is robust enough to resolve satisfactorily all investment disputes between host-country members and home-country members on behalf of their investors. Query whether such disputes should even be justiciable at the WTO. ${ }^{392}$ Assuming that a credible dispute

390 See EdWARD GRAHAM, Global Corporations and National GOVERNMENTS (1996) (arguing in favor of a multilateral investment agreement concluded under WTO auspices).

391 See Sauvé \& Wilkie, supra note 16, at 9.

392 The task of resolving investor-host country investment disputes would probably have to be delegated to other international institutions, such as the International Centre for the Settlement of Investment Disputes. As Sauvé and 
settlement process exists or can be fashioned to resolve tradeinvestment disputes, will the losers have the political will to abide by adverse dispute settlement decisions?

A third condition is a consensus that a comprehensive, global approach to addressing foreign direct investment under WTO auspices is preferable to the incremental approach we now see in existing WTO agreements, coupled with the parallel network of bilateral and regional investment agreements. The provisions in WTO agreements that deal with investment, such as the TRIMs Agreement that shields foreign investors from buy-local laws, thereby ensuring that both foreign and domestic investors are permitted to purchase materials from the lowest-cost source, regardless of its domestic or foreign origin, and the GATS that provides for a commercial presence mode of service delivery, do not address the subject of FDI in a comprehensive fashion. Nevertheless, they represent a promising beginning. Likewise, while it is true that the two sectoral agreements on basic telecommunications and financial services negotiated in 1997 do not deal with investment in a comprehensive or systematic way either, these two agreements do represent genuine market openings to foreign capital and investors in the two sectors covered in the respective agreements. Given the diversity of opinion on the need for and wisdom of a WTO investment agreement, it might make more sense at this time to let the renewed negotiations on services trade serve as a telltale for the prospects of a comprehensive WTO framework agreement on investment, rather than launch headlong into negotiations on a comprehensive, multilateral approach to investment negotiations at the WTO. It arguably would be wiser to move ahead with these follow-on negotiations and build on the achievements of the Uruguay Round before tackling a comprehensive investment agreement. As evidenced by the reservations to investment contained in NAFTA, the majority of which are in services industries, coupled with the lack of genuine market liberalization commitments made in the Uruguay Round in trade in services, ${ }^{393}$ the real liberalization to FDI that needs to occur is in the services area. ${ }^{394}$

Wilkie point out, if private investors were given standing to bring complaints before the WTO, it would be difficult to find a principled basis for denying standing to labor and environmental NGOs. See id. at 13.

393 For suggestions on how the follow-on GATS negotiations should proceed in order to yield greater market liberalization, see id. at 16-20 (recommending, inter alia, clarifying the definition of "commercial presence," strengthening the 
A place to start would be to eliminate the 424 MFN exemptions that WTO members have listed under the GATS Annex to Article II. In addition, as the OECD notes in its study of the GATS MFN exemptions, about half of the 424 MFN exemptions were taken in sectors that provided limited, if any, market liberalization. Audiovisual services and maritime, air, and road transport services, for example, account for $51 \%$ of the MFN exemptions, but the aggregate level of market access commitments is relatively low in comparison with financial services. ${ }^{395}$ At some future date the GATS could serve as a model for the progressive but incremental liberalization of foreign investment in the manufacturing sector. ${ }^{396}$ One can never be sure about such things, but it would seem that services negotiations, including progressive liberalization in the commercial presence mode of supply, will attract less attention from environmental groups, given that services industries are less polluting than traditional smokestack manufacturing industries or other primary industries, such as oil and mineral extraction. ${ }^{397}$

\section{CONCLUDING THOUGHTS}

Whether the WTO can succeed in concluding a multilateral agreement on investment is subject to doubt. Several WTO members (e.g., the EU) have supported such a framework agreement, while others (e.g., the United States) have expressed misgivings and shown reluctance to move forward on meaningful negotiations. ${ }^{398}$ Considering the diverse and broad WTO membership that includes developed, developing, and emerging economies, a strong argument can be made that the WTO is the proper forum for concluding a multilateral investment agreement, not only because of its broad-based membership, but because of the close link between

GATS investment protection provisions, and refining the terminology used in the GATS schedules of commitments).

394 See Alan M. Rudman \& Michael Gastrin, NAFTA's Treatment of Foreign Investment, in FOREIGN INVESTMENT AND NAFTA 47-79 (Alan M. Rudman ed., 1994)95 Trade in Services: A Roadmap to GATS MFN Exemptions, supra note 94, at 15.

396 See WTO Working Group on the Relationship Between Trade and Investment, Communication from Mexico 6-7, WT/WGTl/W/132 (July 8, 2002); Hoekman \& Saggi, supra note 8, at 2; Sauve \& Wilkie, supra note 16, at 15 (claiming that few major barriers to FDI remain in the manufacturing and primary goods industries).

397 See Sauvé \& Wilkie, supra note 16, at 9.

398 See Lawrence J. Speer, WTO Trade Agenda Left Unresolved at Conclusion of OECD Ministerial, 16 Int'1 Trade Rep. (BNA) 914 (June 2, 1999). 
trade and liberalized investment rules. On the other hand, it is misguided to treat developing countries as a monolithic, homogeneous group. Lumping them together and forcing them to bend to the terms of a WTO agreement on investment runs counter to the commitment of special and differential treatment for developing countries found in virtually every WTO agreement, as well as to the letter, if not the spirit, of the Doha Ministerial Declaration and the Development Round agenda. On the other hand, treating developing countries as individual countries with country-specific needs becomes virtually impossible under a multilateral agreement. Bilateral investment agreements offer the flexibility that is not possible under a multilateral framework. BITs can be tailored to fit country-specific needs in a way that is not possible under a multilateral framework. 399

Policy makers and government officials can stick their heads in the sand and ignore the OECD MAI fiasco, but it would be foolish to ignore its lessons. The first lesson is that if a small club of developed countries could not reach a binding agreement on a subject such as foreign investment, where most of the OECD members have a relatively open investment climate, then what chance is there of reaching agreement on foreign investment rules under WTO auspices among 145 economically, politically, and culturally diverse nations? The second lesson is an extrapolation of the first: Again, if a small club of developed countries could not reach a binding agreement on a subject such as foreign investment, where their foreign investment laws are not dramatically far apart, then what chance is there of those same countries, when joined with some 100 other countries in the WTO, of reaching agreement on common investment rules, a subject that touches the sensitive nerve of national sovereignty? The more countries that are involved in the investment negotiations, the more it is advisable to take an incremental approach at the multilateral level. ${ }^{400}$

The economic arguments for an open investment climate may be strong, but those arguments do not necessarily lead inexorably to the conclusion that a multilateral agreement on investment is the

399 But see WTO Working Group on the Relationship Between Trade and Investment, Communication from Canada, Development Provisions para. 14, WT/WGTI/W/131 (July 3, 2002) (suggesting that developing countries can be accommodated under a multilateral investment agreement through phase-in and grace periods that would allow them to build the capacity necessary to comply with the agreement).

400 See LESSONS FROM THE MAI, supra note 21, at 27. 
only correct legal response. While economists make a persuasive argument for the benefits of open markets on the cross-border flow of capital, the devil is in reaching agreement on multilateral rules and institutions for achieving these economic goals. Forcing the bitter pill of international regulation of investment down the throats of countries which are not prepared or willing to accept such rules is a formula for disaster. International agreements must be perceived by the parties as being in their best interests. Developed countries may try to bully less-powerful developing countries into entering into such agreements as the price of continued WTO membership, but adherence to the commitments made in such agreements will be begrudging and cheating at the margins widespread.

Depending upon the precise content of a WTO investment agreement, the potential payoffs of such an agreement would include greater security, stability, predictability, and transparency, thus creating a favorable legal climate for investors. On the other hand, the impact of a WTO investment agreement could be negligible, given the not inconsiderable liberalization that has already taken place worldwide, especially in developing countries and countries in transition. Like BITs, a multilateral agreement on investment is not an end in itself; rather, a multilateral agreement is a means to facilitating investment by allowing economic factors to determine whether and where an investment is made. Moreover, a WTO agreement on investment is really beside the point if a potential host country does not have the fundamentals firmly in place: political stability, desirable geographic location, adequate infrastructure, human capacity, functioning legal institutions and enforceable contract rights, intellectual property protection, and open trade policies. 401

Would such an agreement reduce international frictions in the area of transnational mergers and acquisitions, an increasingly popular mode of entry into a foreign markets? International M\&A activity is a global concern because it can reduce the competitiveness or contestability of a market. Such activity is of special concern to the national authorities of the acquired firm because it represents a diminution of national sovereignty and control over domestic enterprises. The growth in FDI underscores the importance to some of concluding a WTO competition policy agreement

401 See Hoekman \& Saggi, supra note 8, at 21. 
that takes into account these transborder concerns. In 1997, for example, worldwide cross-border M\&A activity totaled $\$ 342$ billion. That figure nearly tripled in 2000 to $\$ 1.1$ trillion, nearly $50 \%$ greater than in 1999.402

The debacle at the WTO's Seattle Ministerial Conference in December 1999 was in part fueled by myths and misinformation about the WTO, free trade, and globalization. It is true that accelerated trade liberalization worldwide has led to the increased globalization of business and the interdependence of national economies. But many environmental and workers' rights groups view the world as a zero sum game: to the extent the WTO succeeds at promoting globalization, then to the same extent the environment and labor rights suffer in direct proportion. Environmental doomsayers proclaim that we are on the brink of a global environmental collapse, thanks in no small part to free trade. It is difficult not to be a bit skeptical when labor unions decry the labor rights record of developing countries. One cannot help but wonder whether they silently fear global economic interdependence and wish sub rosa for autarchy. In the words of former presidential economic adviser Murray Weidenbaum:

If the full policy agenda of the anti-global activists were adopted, the long-run effect would be for the United States and other industrialized nations to lose the benefits of the specialization of labor, and suffer severe declines in standards of living. Ironically, the economic costs would soon be translated into environmental costs. Wealthier countries can afford to devote more resources to achieving a cleaner environment, and they do so. Poorer countries do far less to clean up the environment. ${ }^{403}$

Nevertheless, from the integration of national economies it does not inexorably follow that negotiating a multilateral legal regime regulating foreign investment, let alone a multilateral agreement under WTO auspices, is necessarily the right approach. Mul-

${ }_{402}$ See WORLD INVESTMENT REPORT 2001, supra note 374, at 10 . See generally KeVIN KENNEDY, COMPETITION LAW AND THE WORLD TRADE ORGANISATION; THE LIMITS OF MULTILATERALISM (2001).

403 Murray Weidenbaum, Globalization Myths, CHRISTIAN SCI. MONITOR, Dec. 16,1999 , at 9 . 
tilateralism is no panacea. Indeed, it has limits that policymakers need to recognize. The legal and political arguments against such an approach are formidable and convincing. Forcing the liberalization of domestic laws on foreign direct investment may, in the end, be a solution in search of a problem. Although we do not live in a market economist's perfect investment world (i.e., a world that is barrier free to the flow of investment capital from whatever source), bilateral and regional agreements on investment, WTO commitments on non-discrimination and market access to goods and services, not to mention unilateral "disarmament" in the form of domestic laws that remove barriers to foreign investment, have made any multilateral investment agreements in large part redundant.

The WTO is in many respects a "natural" forum for negotiating an investment agreement. Still, there is nothing in the WTO's constitution that makes a WTO agreement on FDI necessary, inexorable, or preordained. Indeed, the absence of any multilateral FDI agreement-which was underscored in 1998 with the collapse of the OECD MAI-might not reflect a WTO lacuna or failure, but rather might be compelling evidence that a critical mass of political will among the world's developed countries has failed to build, since the end of World War II, such an agreement. It has not been for lack of trying that a multilateral investment agreement has not been concluded. On the contrary, it has been much discussed in other international fora, including the OECD and UNCTAD. At least one conclusion to be drawn from these discussions and negotiations is that the world is not ready for, does not want, and/or does not need a multilateral agreement on investment.

The WTO's prestige, reputation, and authority are at an alltime low. The United States, its most powerful membei, has been ambivalent at times in its support of the WTO and its goal of promoting liberal trade. The commitment of the United States to U.S. participation in the WTO is less than whole-hearted. ${ }^{404}$ But even

404 Despite the U.S. Trade Representative's ringing endorsement of continued U.S. membership in the WTO in her March 2000 Report, 2000 TRADE POLICY AGENDA AND THE 1999 ANNUAL REPORT OF THE PRESIDENT OF THE UNITED STATES ON THE TRADE AGREemEnTS Procram, a resolution was introduced in Congress in 2000 calling for U.S. withdrawal from the WTO pursuant to section 125 of the Uruguay Round Agreements Act, 19 U.S.C. $\$ 3535$ (mandating a five-year review of U.S. participation in the WTO). Gary G. Yerkey, USTR Sends Report to Congress Urging Continued U.S. Participation in WTO, 17 Int'1 Trade Rep. (BNA) 394 (Mar. 9, 2000). That resolution was defeated in the House of Representatives on June 21, 2000, by a vote of 363 to 56 . Corbett B. Daly, House of Representatives Affirms 
the most vocal government critics of the WTO have called for reform of the Organization, not for U.S. withdrawal from it. ${ }^{405}$ At the same time, intemperate and pandering remarks by former President Clinton at the WTO Seattle Ministerial Conference, suggesting that the WTO conclude an agreement on core labor standards that would be enforced through trade sanctions, steeled the resolve of developing countries not to be steamrolled by the WTO's developed-country members in the next WTO trade negotiation round.

All of these developments are unfortunate because the WTO, unlike virtually every other inter-governmental organization in the world, sets rules that bind rich countries and poor countries alike. The big losers from the debacle in Seattle were developing countries. Of all the things that developing countries need-corruptionfree government and the other institutions that make capitalism work-open markets for foreign goods, services, and capital are probably the easiest to create. A liberal trade policy is a policy of increased competition and opportunity. Such a policy holds great promise not only for developed countries, but for the developing countries of the world as well.

In sum, with the collapse of the OECD negotiations on a Multilateral Agreement on Investment, the spotlight has shifted to the WTO as the forum for possibly concluding such an agreement. Moving the discussions on a multilateral investment agreement from the OECD to the WTO could simply be a case of pouring old wine into a new and bigger bottle. With the collapse of negotia-

American Membership in World Trade Organization, 17 Int'l Trade Rep. 975 (June 22, 2000). See Press Release, Office of the USTR, USTR Barshefsky Hails Overwhelming House Vote on WTO, Bipartisan Vote Rejects U.S. Withdrawal from WTO (June 22, 2000).

405 See Corbett B. Daly, Ways and Means Panel Rejects Resolution Calling for U.S. Withdrawal from WTO, 17 Int'1 Trade Rep. (BNA) 923 (June 15, 2000); Gary G. Yerkey, USTR Set to Issue Report Defending Continued U.S. Participation in WTO, 17 Int'l Trade Rep. (BNA) 341 (Mar. 2, 2000) (noting that House Minority Leader Richard Gephardt continues to support U.S. participation in the organization, but believes that dispute settlement system needs to be reformed). In August 2002, Congress approved and President Bush signed the Trade Act of 2002 which, inter alia, renews the President's trade promotion authority to negotiate multilateral trade agreements without subsequent amendments to such agreements by Congress. See Trade Act of 2002, Pub. L. No. 107-210, §§ 2101-13,116 Stat. 933, 9921022 (2002). Trade promotion authority was formerly known as fast-track negotiating authority. For a description of fast-track negotiating authority and procedures, see Harold Kongju Koh, The Fast Track and United States Policy, 18 BROOK. J. INT'L L. 143 (1992); Alan F. Holmer \& Judith H. Bello, The Fast Track Debate: A Prescription for Pragmatism, 26 INT'L LAW. 183 (1992). 
tions on the proposed OECD Multilateral Agreement on Investment in 1998, attention turned almost by default to the WTO as the sponsor of negotiations on a WTO investment agreement. The lesson for the WTO from the MAI debacle is clear: Tread lightly. The MAI negotiators' expectations were unrealistically high and thus failed to garner the necessary critical mass of support that was required for a multilateral investment agreement.

Although no comprehensive WTO agreement regulating all aspects of FDI currently exists, the GATT-WTO system does integrate trade and FDI in several important respects, most notably with the commercial presence mode of supply under the GATS. The fact that developed-country economies are today overwhelmingly services-based and are net exporters of FDI strengthens the case, at least for developed countries, for further liberalization in services trade. This fact at the same time weakens the argument for WTO negotiations on a comprehensive, framework investment agreement. Even though the treatment of FDI in WTO agreements is fragmented and limited, there is no urgency to launching negotiations on a WTO investment agreement. The WTO's raison d'être to progressively liberalize trade in goods and services could be jeopardized if linkages are made in negotiations between investment and nontrade issues, such as labor and environment. ${ }^{406}$ Given the many linkages between trade and nontrade areaslabor, environment, competition policy - a Pandora's box could be opened if serious negotiations get underway in the WTO on an agreement on investment. 407

406 See Hoekman \& Saggi, supra note 8 , at 23. See also Symposium, The Boundaries of the WTO, 96 AM. J. INT'L L. 1 (2002) (addressing the phenomenon of linkage between trade and other nontrade issues).

407 See Jagdish Bhagwati, Powerful Reason for the MAI to be Dropped Even from the WTO Agenda, FIN. TIMES, Oct. 22, 1998, at 17. 